Thais Helena Mourão Laranjo

\title{
O CRUSP: processos de socialização e consumo de drogas
}

\author{
Dissertação apresentada à Escola de \\ Enfermagem da Universidade de São Paulo \\ para obtenção do título de Mestre em \\ Enfermagem - Área de Concentração \\ Enfermagem em Saúde Coletiva
}

Orientadora: Profa.Dra. Cássia Baldini Soares

São Paulo

2003 
Laranjo, Thais Helena Mourão

O CRUSP: processos de socialização e consumo de drogas /

Thais Helena Mourão Laranjo. - São Paulo: T.H.M.Laranjo; 2003.

$140 \mathrm{p}$.

Tese (Mestrado) - Escola de Enfermagem da Universidade de São Paulo. Orientadora: Cássia Baldini Soares

1. Socialização 2. Juventude 3. Drogas de uso indevido I. Soares, Cássia Baldini, orient. II. Título. 
$\mathcal{A}$ vida não tem pena de ninguém Será que somos robôs programados para dizer amém? (Paulinho Moska - Amém) 


\section{Agradainatios}

Os agradeeimentos não serão feitos por ordem de importânaia, pais eta seria umatarefaimposśve.

Gostaria de agradecer a Escola deEnfermagem ao Departamento de Pós Graduação e espeeificamente as professoras do Departamento de Enfermagem em Saúde Coleiva por terem dado a oportunidade, pala primera vez, para uma psicóloga real izar seu mestradonessedepartamento.

A minha crientadora querida, amiga e fundamental emtodb o meu processo de aprendizado nessetrabal ho aqui expresso meu reconheimento e gratidão.

Aos al unos moradores do CRUSP o meu reconhed mento pela acd hida emseus apartarmentos e pela disponibilidade em priticipar das entrevistas. Valeurmoçada!!

Ao meu dhefe Dr. André Mal bergier o meu mito dorigado por tre incentivar a realizar essetrabalho.

Aos meus pais o agradeimento pda vida e pelos valores que tre ensinaramequemetomaramuma pessoa persistente

Ao Dani, meu Anjo ecompanhero de vida o meu carinho, pais parte desse trabalho tema ver com o apoio que você me deu durante todo o processo, mestro quandb eu mesta não sabia seconseguiria dhegar ao fim

Aos amigosWillian Winkler eCdi J over palaajudana "retafinal".

Aos meus imãos, aunhado, sobrinhos e amigos, dorigada por tre acompanharemna minhatrajecóia devida compaciência ecarinho. 


\section{Resumo}

O presente trabalho teve como objetivo conhecer e analisar o discurso dos moradores sobre os processos de socialização no Conjunto Residencial da USP - CRUSP destacando o consumo de drogas. Tomou-se a moradia como um espaço de socialização juvenil que viabiliza a presença de estudantes pobres na universidade e que poderia estar relacionado a um certo consumo de drogas. Foram entrevistados 20 alunos de graduação. As entrevistas além da caracterização sócio-econômica abordaram três aspectos: o conhecimento dos alunos sobre a história do CRUSP, a experiência de morar no CRUSP (aspectos positivos e negativos) e a visão dos moradores sobre o uso de drogas. Nesta pesquisa qualitativa o procedimento metodológico que serviu de base para a coleta e organização do material proveniente das entrevistas é denominado "Discurso do Sujeito Coletivo" (DSC). Os resultados foram apresentados em forma de "Discurso do Sujeito Coletivo". Pôde-se perceber que os alunos têm pouco conhecimento sobre a história do CRUSP, que as alternativas para os problemas vividos pelos alunos na moradia têm sido encontradas individualmente, o que reflete a ideologia do capitalismo neoliberal e no que se refere ao uso de drogas, assim como na sociedade em geral, estão presentes as duas principais concepções que contemporaneamente têm alimentado a arena da prevenção ao consumo de drogas: guerra às drogas e redução de danos.

DESCRITORES: socialização, juventude, drogas de uso indevido 


\section{ABSTRACT}

The aim of this paper is to analyse and acknowledge the speech of dwellers on their socialization processes in the University of São Paulo's halls of residenceCRUSP, highlighting the risks of drug intake. Such dormitories were taken as a space for juvenile socialization which enables the attendance of needy students quite likely to be related to abuse drugs. Twenty undergraduates were interviewed. Interviews beyond the socioeconomic characterization comprised three aspects: students' awareness about CRUSP's history, experience in living in CRUSP (drawbacks and advantages) and their view on drug use. In this qualitative research, all collection and compilation of information obtained in the interview was grounded on the "Collective Subject Speech" methodological process. All results were presented in such format. It was noticeable that students have little knowledge about the history of CRUSP, and that alternatives for the problems experienced by these students have been found individually, which in its turn recalls the neo-liberal capitalism ideology. Also, as regards drug intake, as well as society in general, this study observes the two main existing conceptions which have been building the drug prevention arena: war on drugs and harm reduction.

KEY-WORDS: socialization, youth, drugs 


\section{Sumário}

1 Introdução e justificativa: o objeto e o problema de estudo............................ 8

1.1. A história não-oficial do CRUSP ................................................... 11

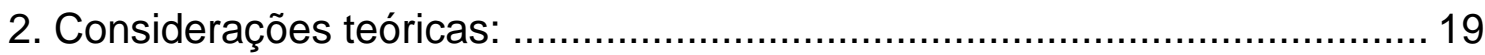

2.1. O consumo contemporâneo de drogas........................................... 19

2.2. A juventude universitária e suas marcas culturais ..............................21

2.3. Bases para pensar a prevenção ................................................ 26

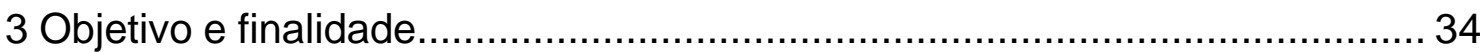

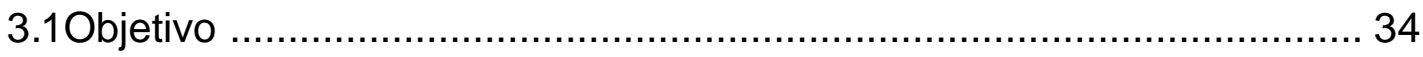

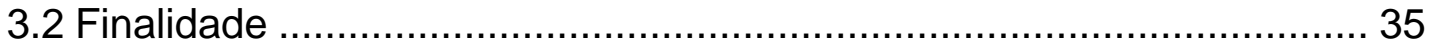

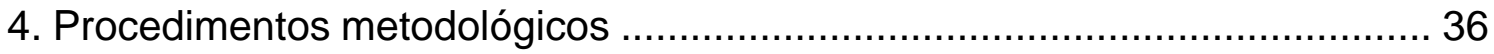

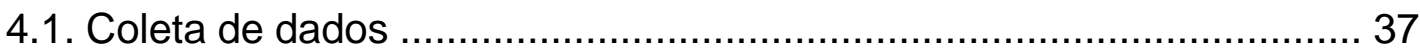

4.2 Caracterização dos alunos do Conjunto Residencial da Universidade

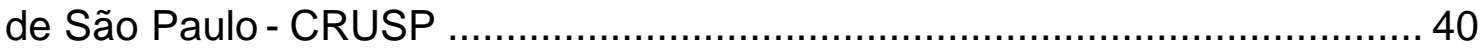

5. Procedimentos para análise dos dados ................................................... 44

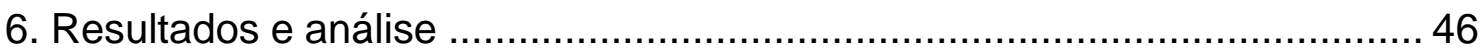

6.1. Quem são os moradores que constituíram os sujeitos da pesquisa .... 46

6.2. O que dizem os moradores do CRUSP sobre a história do CRUSP ... 50

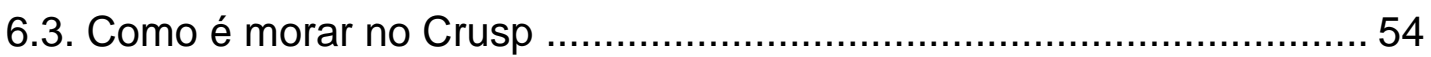

6.4. A visão dos moradores sobre o consumo de drogas ............................ 89

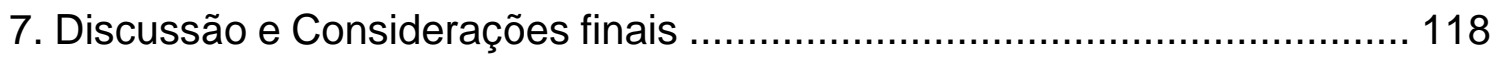

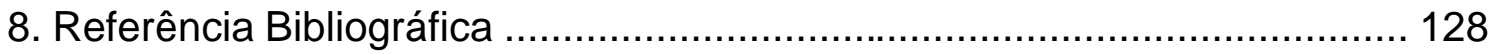

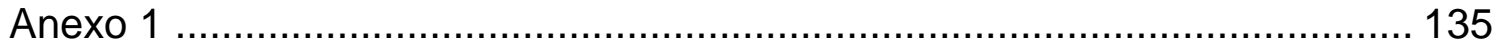

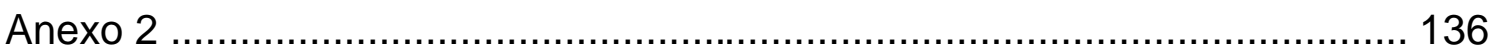

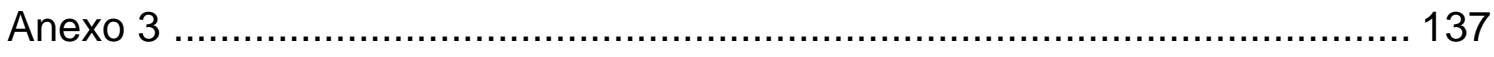

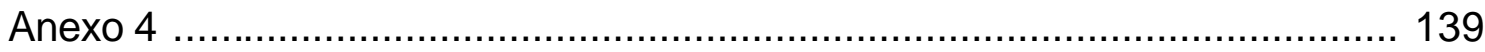




\section{Introdução e justificativa: o objeto e o problema de estudo}

O objeto deste estudo se refere ao discurso de jovens universitários sobre o consumo de drogas conforme mediado pelos processos de socialização no contexto específico da moradia estudantil.

A partir da década de 80, o Brasil passou a ser o país latino americano com mais dados sobre dependência, bem como sobre padrões de uso de álcool e drogas em populações específicas (Kerr-Corrêa e col 1999). A revisão bibliográfica revela um número expressivo de estudos epidemiológicos que se referem ao conhecimento da incidência e prevalência do consumo de drogas em populações específicas tais como: escolares (Galduróz e col 1997, CarliniCotrim 1991), universitários (Andrade e col 1997a, Kerr Correa e col 1999, Queiroz 2000), crianças em situação de rua (Noto e col 1998) e populações que constituem demandas por serviços de tratamento (Schivoletto 1997).

Particularmente, em relação aos universitários, esses estudos vêm sendo realizados desde a década de 70 (Zanini 1977, Magalhães e col 1989, Borini e col 1994, Andrade e col,1997). Há uma preocupação tanto com os universitários em geral (Andrade e col 1997, De Lucia e Planeta 1989, Magalhães e col 1991, Boskovitz e col 1995, Bucher e Totugui 1988, Brenes e col 1986, Queiroz 2000) como com as possíveis diferenças de consumo por área acadêmica. Nesse caso, os mais estudados são os alunos da área de biológicas, mais especificamente os dos cursos de medicina (Borini e col 1994, Andrade e col 1995, Andrade e col 1997, Mesquita e col, 1995, Kerr-Correa, 1999). Mas não foram encontrados estudos que abordem os estudantes universitários na condição específica de moradores de repúblicas estudantis ou de moradia oferecida por uma Universidade, particularidade que corresponde à conformação do objeto do presente trabalho. 
Esses estudos se caracterizam pela preocupação em estabelecer quais as drogas mais usadas, qual o padrão de uso, qual o perfil do usuário, quais as atitudes destes sobre o consumo de drogas e quais os fatores que podem levar ao uso ou experimentação caracterizando-se como levantamentos epidemiológicos de natureza descritiva. Carlini e col (1994) também verificaram essa tendência nos trabalhos científicos sobre o tema drogas em geral, pois a partir da análise do Banco de dados do CEBRID (Centro Brasileiro de Informações sobre Drogas) constataram que a maioria das pesquisas registradas nesse centro consistia em levantamentos epidemiológicos, especificamente sobre epidemiologia do uso.

Essas pesquisas têm se utilizado de questionário de auto-preenchimento, anônimo, com perguntas fechadas de múltipla escolha. Os dados são analisados estatisticamente e a partir daí são feitas associações entre algumas variáveis. Em alguns trabalhos é realizada uma caracterização sóciodemográfica dos participantes da pesquisa que inclui: idade, estado civil, ano e tipo de curso, situação de moradia (com pais ou não), renda familiar (em alguns casos) e escolaridade dos pais. Porém, variáveis sócio-econômicas que indiquem a condição de classe social dos sujeitos pesquisados não são incluídas na maioria dos estudos. Nos que levantam esses indicadores, prevalece uma análise descritiva. Há explicitamente um recorte dos sujeitos de pesquisa que os reduz à condição de usuários de drogas, sem remetê-los à sua classe social ou às condições em que se instalam consumos prejudicais de drogas.

Os levantamentos epidemiológicos estão interessados no diagnóstico quantitativo do uso das diferentes substâncias e nos fatores que podem motiválo. Embora, em alguns casos, se baseiem no conceito de que os problemas associados ao uso de drogas se devem a três fatores - biológicos, psicológicos e sociais - apresentam em suas conclusões apenas as motivações individuais, ou seja, aspectos que são percebidos como de responsabilidade do indivíduo. Os aspectos relativos à classe social e à cultura do sub-grupo estudado (universitários, por exemplo), não são mencionados. 
Os estudos realizados com os alunos da USP (Andrade e col 1995, Andrade e col 1997, Barría 2000, Queiroz 2000) também se constituem em levantamentos epidemiológicos do uso de drogas. Algumas associações sobre uso de drogas por universitários têm levado a crer que o fato de morar longe da família aumenta a chance do uso de drogas (Boskovitz e col 1995, Andrade e col 1997, Queiroz 2000). No caso da USP, essa afirmação é particularmente delicada, pois colabora para a manutenção do estigma de que morar no CRUSP (Conjunto Residencial da USP) significa ser liberal com relação ao uso de drogas ou mesmo usuário, o que remete ao ideário de ser problemático em vários outros aspectos da vida ${ }^{1}$ (Velho 1999).

A associação feita nesses estudos entre as variáveis morar fora de casa (no CRUSP) e o uso de drogas merece melhor compreensão. Esse aprofundamento se relaciona também a uma compreensão mais ampla do significado de morar no CRUSP, ou viver a sociabilidade juvenil sob tais condições de moradia.

São os estudos qualitativos relativos ao tema drogas e universitários que, embora apareçam em menor número (Magalhães e col 1989, Santos e col 2000), tratam de analisar de maneira mais aprofundada os elementos envolvidos na problemática, dificilmente identificados pelos estudos epidemiológicos. No estudo realizado por Magalhães e col (1989) sobre freqüência do uso de maconha por universitários, pode-se notar que as mudanças nos padrões de sociabilidade e de inserção social foram apontadas pelos alunos como capazes de afetar a freqüência de uso, e que idéias préconcebidas a respeito do padrão de uso de maconha - droga polêmica e que figura em primeiro lugar dentre as drogas ilícitas consumidas por jovens podem não se confirmar, necessitando de exploração científica. No estudo conduzido por Santos e col (2000), com universitários da área de saúde, podese constatar que para os alunos o meio universitário estimula o uso abusivo de

\footnotetext{
${ }^{1}$ Embora não existam trabalhos sobre isso, a constatação feita é linguagem corrente na Universidade. Durante meu trabalho no PRODUSP tenho presenciado essa fala com muita freqüência.
} 
álcool, que este consumo é visto como moda e sinal de maturidade e que atitudes contrárias ao uso levam o sujeito ao isolamento.

As críticas sobre a forma como vêm sendo conduzidos os estudos científicos relativos ao tema drogas não devem obscurecer a importância da realização de pesquisas epidemiológicas, pois a alternativa para que se possa sair do patamar do senso comum, transmitido pelos meios de comunicação e pelos projetos de prevenção, é a realização de pesquisas científicas (Carlini e col 1994).

Não se trata, portanto, de enfatizar a importância de uma ou outra abordagem metodológica, uma vez que objetiva-se níveis de apreensão da realidade diferentes entre si. Deve-se estar atento, no caso das pesquisas quantitativas, para não se restringir a realidade social ao observável, contável e possível de apreensão empiricamente (Minayo 1999). Dessa forma, se o pesquisador pretende alcançar um maior aprofundamento da realidade não deve se restringir a um referencial quantitativo (Minayo 1999). Até mesmo porque uma postura dialética impõe a qualificação de dados quantitativos para serem compreendidos no contexto histórico em que foram coletados, referindose o fenômeno observado à totalidade.

O conjunto problematizador deste estudo se refere às seguintes indagações: como os jovens percebem os espaços e processos de socialização da moradia estudantil? $O$ fato de morar num conjunto residencial estudantil teria relação com uma percepção socialmente diferenciada a respeito do consumo e dos consumidores de drogas? E que sugestões os moradores têm sobre como deveria ser a prevenção ao uso de drogas na moradia?

\subsection{A história não-oficial do CRUSP}

O resgate da história do CRUSP - Conjunto Residencial da USP - não é tarefa simples pois, embora existam documentos de diversas ordens (artigos de 
jornal, documentos internos da USP, livro e vídeo) que retratam essa história sua localização não é tarefa fácil. Não menos difícil é encontrar a história do CRUSP contada como parte integrante da história da USP. Um ex-aluno e exmorador do CRUSP que escreveu um livro sobre morar no CRUSP afirma no prefácio que as histórias ali presentes se referem a sua própria experiência como morador e a relatos orais, devido a sua dificuldade em localizar documentos antigos (Cunha, s/d, p.2).

Assim como Cunha ( $\mathrm{s} / \mathrm{d})$ verifica-se que a reconstrução da história do CRUSP também é dificultada pela parcialidade e falta de transparência com que são descritas as situações vividas por alunos moradores em sua relação com a universidade e com o Estado. Foi através da leitura de artigos dos jornais Folha de São Paulo, O Estado de São Paulo e Jornal da Tarde que se pôde perceber 0 quanto fatos descritos nos documentos de forma acética apresentavam implicações políticas importantes.

Para a organização do histórico aqui apresentado foram consultados documentos internos da COSEAS (s/d) - Coordenadoria de Assistência Social da USP, que não estão disponíveis para o público e artigos de jornais sobre o CRUSP e o livro O espaço da USP: presente e futuro (USP 1985). ${ }^{2}$

A análise do material revela uma história de descaso da Universidade em relação ao CRUSP. Verifica-se que a proposta de oferecimento de uma moradia para os estudantes como alternativa para democratizar o acesso foi obscurecida, pois a Universidade negligenciou a administração da moradia desde o início, posicionando-se apenas nos momentos de crise.

Para compreender a origem da idéia de se construir uma residência estudantil dentro do campus da universidade se faz necessário recorrer ao modelo de universidade presente no projeto da USP.

O projeto inicial da Universidade de São Paulo teve, portanto, como modelo os projetos das universidades americanas, que propunha a moradia para os alunos dentro do campus.

2 Pesquisa bibliográfica sobre a USP patrocinado pela Prefeitura da Cidade Universitária "Armando de Salles Oliveira", em 1985. 
O projeto inicial do CRUSP foi premiado no $12^{\circ}$. Salão Paulista de Arte Moderna e previa a construção de doze prédios com seis andares. A decisão de que cada apartamento alojaria três estudantes foi do FUNDUSP (Fundo de Obras da USP). Os motivos para tal decisão são desconhecidos.

Durante o governo de Ademar de Barros, em São Paulo, foram construídos seis prédios do CRUSP que inicialmente abrigariam os atletas dos jogos Pan Americanos de 1963 e posteriormente seriam destinados aos estudantes.

Os prédios ficaram prontos, mas os jogos não se realizaram em São Paulo devido a um surto de meningite. Os estudantes ocuparam os apartamentos e nesse momento a USP ainda não tinha desenvolvido uma política para as moradias estudantis.

Atualmente sabe-se que a política da Universidade para a moradia já estava descrita naquela época em um documento intitulado "Diretrizes e regras adotadas em caráter experimental". E que em 1964 o Conselho Universitário aprovou um regimento para o CRUSP que só foi normatizado em 1966. Essa normatização incluía o pagamento de taxas e as formas de organização e incumbências dos representantes dos alunos. Não há informação disponível sobre a implementação dessas regras.

Mas sabe-se que o que regulamentava a vida no CRUSP eram as assembléias organizadas pela AURK (Associação Universitária Rafael Kaun), entidade representativa dos moradores. Nesse período a vida política e cultural no CRUSP era intensa e as atividades eram promovidas também pela AURK.

Em 1968 ficou pronto mais um bloco do CRUSP que passou a ser ocupado pelo ISSU (Instituto de Saúde e Serviço Social da Universidade). Mas devido a necessidade de vagas os estudantes acabaram por ocupá-lo. A organização e seleção dos moradores nesse novo prédio acabou ficando a cargo da AURK.

Neste momento o Brasil vivia sob a ditadura militar, a repressão se intensificava, os líderes estudantis foram presos e o CRUSP era um dos únicos lugares onde ainda os estudantes se reuniam e discutiam diferentes tendências 
políticas, atividade proibida na época. Essa conjuntura culminou com a invasão da polícia repressiva que espancou e expulsou os alunos, deixando os prédios vazios. Esse foi mais um recurso utilizado pelas forças repressoras do Estado para desmobilizar politicamente os estudantes.

O livro "O espaço da USP: presente e futuro" acima citado refere que após a invasão e com o esvaziamento dos prédios esses acabaram por se destinar a várias finalidades. Segundo os documentos da COSEAS dentre elas estavam as salas de aula da Faculdade de Letras, posto do Banespa (Banco do Estado de São Paulo), Museu de Arqueologia, alojamento para estrangeiros e para estudantes de fora da grande São Paulo de passagem rápida pela cidade, mas os critérios utilizados para a seleção desses alunos não eram claros. Para servir a esses novos fins houve mudanças na estrutura inicial dos apartamentos.

Será então a partir de 1979 sob o clima nacional de reabertura política que os alunos retomarão o CRUSP como moradia, ocupando dois andares do bloco A. dois anos seguintes os alunos continuaram ocupando o espaço da moradia e a Universidade não se posicionou quanto a isso.

Em 1982, o então coordenador da COSEAS compareceu a uma assembléia de moradores e reconheceu que o CRUSP retomou suas funções ser moradia para estudantes - e assumiu um compromisso verbal de que no próximo ano iniciariam-se as reformas no CRUSP, que seria ativado um serviço de manutenção dos prédios e teriam inicio as negociações com os moradores para elaborar um estatuto para a moradia. No cenário político acenava-se para as eleições estaduais.

Já em 1983, o coordenador da COSEAS anunciou que os blocos destinados a Faculdade de Letras se transformariam em moradia novamente e dentre as medidas propostas estava a cobrança de taxa de manutenção. Os professores do departamento de Letras em entrevista à Folha de São Paulo (Docentes 1983) denunciaram que embora tivesse sido anunciado que 0 departamento deixaria o CRUSP, possibilitando a abertura de 300 novas vagas na moradia, isso ainda não estava acertado. Os professores não tinham ainda 
para onde ir e temiam que esse anúncio feito pelo coordenador da COSEAS criasse um impasse entre eles e os alunos.

Segundo o jornal a Folha de São Paulo, (Moradores 1983) a maioria dos alunos acreditava que esse anúncio feito pela COSEAS era uma estratégia de divisão dos moradores em oficiais e não oficiais, criando uma rivalidade entre eles. Além disso, repudiavam a idéia de cobrança de taxa e queriam participar do processo seletivo para os novos moradores. Por outro lado, passados 20 anos da construção da moradia, a Divisão de Promoção Social divulgava a idéia de que a grande novidade era que a universidade assumiria a questão da moradia.

No mesmo período o jornal o Estado de São Paulo (CRUSP 1983) publicava que embora tivessem se passado quatro anos desde que os blocos $\mathrm{A}$ e $F$ haviam sido tomados pelos alunos, a universidade não sabia informar quem eram esses moradores, mas sabia que os prédios não apresentavam nem segurança e nem infra-estrutura para que as pessoas pudessem habitá-los.

A COSEAS abriu inscrições para os novos moradores e os antigos moradores fizeram a mesma coisa. Foi então realizada uma reunião para discutir o impasse relacionado a criação das novas vagas com a participação de moradores e da COSEAS na presença de jornalista da Folha de São Paulo. Nessa reunião os alunos anunciaram que formariam uma comissão de negociação e que forneceriam a lista de moradores. A assembléia geral do CRUSP, realizada após essa reunião aceitou a negociação com a COSEAS e estabeleceu que os $2^{\circ}, 4^{\circ}, 5^{\circ}$ e $6^{\circ}$. andares do bloco $B$ e os $2^{\circ}, 3^{\circ}, 4^{\circ}, 5^{\circ}$ e $6^{\circ}$ do bloco $\mathrm{C}$ seriam áreas de litígio e não poderiam ser ocupados por nenhuma das partes até que o impasse se resolvesse, a COSEAS aceitou essas resoluções.

O conflito entre a universidade e os alunos continuava se manifestando de diversas formas. A próxima reunião entre moradores e COSEAS foi adiada, pois o coordenador da COSEAS foi nomeado secretário das finanças do município. A diretora da DPS (Divisão de Promoção Social) passou a responder pela COSEAS, participando das negociações com os alunos. Manteve-se um 
impasse nas negociações, os alunos solicitaram que antes de qualquer coisa deveria ser estabelecida a gratuidade da moradia, mas a COSEAS pretendia discutir uma política global. Diante dessa situação os alunos invadiram os blocos $\mathrm{B}$ e C.

Em 1984 constituiu-se o comitê de defesa da moradia estudantil formado por representantes de entidades estudantis, Associação dos Docentes da USP (ADUSP), Associação dos Servidores da USP (ASUSP) e parlamentares. Estabeleceu-se que a seleção dos moradores seria feita pela COSEAS, teria caráter classificatório e seria baseada em critérios sócio-econômicos, o Diretório Central dos Estudantes (DCE) seria responsável pela inscrição dos interessados e os moradores seriam responsáveis pelo levantamento do número de vagas. Neste mesmo ano a COSEAS finalmente solicitou à Escola Politécnica uma reforma nos prédios do CRUSP.

O jornal o Estado de São Paulo (As obras 1984) publicou que com o início das obras no CRUSP, a polícia pôde invadi-lo e fazer a retirada de marginais que lá moravam. No entanto, chama a atenção que os tais marginais, ainda segundo a reportagem, não ofereceram resistência à evacuação do prédio "sem violência e sem a necessidade de se recorrer à tropa de choque, está se conseguindo retirar esse pessoal" (O Estado de São Paulo, 1984, p.15). $\mathrm{Na}$ mesma época a Folha de São Paulo (Degradação 1984) publicou artigo enfatizando que "a degradação urbana e social chegou ao campus da mais importante instituição de ensino superior do país".

Assim vai se construindo a imagem do CRUSP como um lugar perigoso e habitado por bandidos, marginais e delinqüentes. Nenhum dos artigos de jornal ou documentos consultados apresentou os aspectos positivos da moradia estudantil. O único aspecto valorizado foi o fato do projeto inicial da estrutura do CRUSP ter sido premiado e isso na década de 60.

O ápice dos problemas no CRUSP evidenciou-se com a morte de dois alunos, em novembro de 1984, durante uma festa na moradia. Houve uma briga, os alunos caíram do quarto andar do bloco A e segundo artigo do Jornal da Tarde (Briga 1984) o que teria provocado a morte dos estudantes seria a 
fragilidade das placas e janelas do CRUSP. No entanto, a ênfase dada nos artigos de outros jornais foi a necessidade de expulsão dos marginais, pessoas estranhas à Universidade (Duas mortes 1984). Esse fato gerou uma série de mudanças na moradia.

A partir daí a COSEAS assumiu o gerenciamento do CRUSP e publicou no Diário Oficial de 23/11/84 o regimento definindo normas para ocupação e permanência na moradia. Esse regimento previa sua reformulação com a participação da Associação dos Moradores. Essa associação foi criada em dezembro do mesmo ano, chamada então de AMORCRUSP (Associação de Moradores do CRUSP) (Moradores 1984).

As negociações não avançaram, pois a COSEAS queria retirar os moradores para realizar as reformas e esses queriam garantias de que poderiam voltar ao CRUSP. A COSEAS e a Reitoria desmarcaram reunião e os alunos interpretaram isso como falta de disponibilidade para negociar. Mais uma vez essas instâncias não chegaram a um acordo. Mesmo assim as reformas aconteceram e em 1985, foram concluídas aquelas tidas como essenciais pelo Instituto de Pesquisas Tecnológicas (IPT) e pela Escola Politécnica.

Em 1987 a COSEAS publicou novo regimento com o conceito de bolsa moradia, onde os critérios mais importantes para a seleção passaram a ser 0 sócio-econômico e o desempenho acadêmico. No final desse ano foi eleita nova chapa da AMORCRUSP, que passou a discutir com a COSEAS os critérios acadêmicos a serem incluídos no novo regimento. Através de uma consulta aos moradores estabeleceram, em acordo com a COSEAS, que para a renovação da bolsa-moradia o mínimo de créditos exigidos seria o necessário para que o aluno completasse o seu curso em 1,5 vezes o tempo mínimo de duração, definiu-se também que para resolver os casos de alunos que não cumprissem essa regra e entrassem com recurso seria consultada uma comissão tripartite formada pela COSEAS, DCE e AMORCRUSP.

Em 1989, a COSEAS e a AMORCRUSP se reuniram para discutir as condições de permanência no CRUSP dos não-moradores - os hóspedes. $O$ 
acordo estabelecido foi que os alunos da USP poderiam ser hospedados nos apartamentos desde que houvesse consentimento dos três moradores até a seleção para novos moradores e isso se daria por um número indefinido de vezes. Com isso ficou acordada a possibilidade da existência do quarto morador.

Em 1994 mais um fato trágico levou o CRUSP às notícias de jornais, um aluno que caiu no poço do elevador e se feriu gravemente. Posteriormente a esse fato a Reitoria deu início às negociações com estudantes para definição de um novo regimento e ao plano de reforma dos prédios. 


\section{Considerações teóricas:}

\subsection{0 consumo contemporâneo de drogas}

Existem registros muito antigos sobre o uso de drogas em várias sociedades. Em momentos históricos e em culturas distintas, a compreensão sobre o uso e os valores a ele associados são diferentes entre si e dos encontrados atualmente nas culturas ocidentais. Essas diferenças se devem à influência da organização política, social e econômica no modo de pensar e agir das pessoas. A proibição e a permissão do uso de determinadas substâncias também são fenômenos historicamente determinados e relacionados a uma complexa trama de interesses (Escohotado 1994).

De acordo com Kaplan (1997), o processo de afirmação acentuada do narcotráfico nas últimas décadas não se constitui em um "desequilibro do sistema", como poderia se interpretar numa visão funcionalista, mas em uma resposta à globalização que vem se caracterizando pelo alto grau de concentração de poder nos países de capitalismo central. Os países latinoamericanos sofrem poderosas restrições externas a seus interesses nacionais. Tal interpretação está associada a uma visão histórico-crítica do narcotráfico. Assim, do ponto de vista interno dos países, o narcotráfico partiria das insuficiências e distorções do crescimento econômico desigual, da desestabilização política e da constelação enorme de conflitos que daí derivam. Há portanto nesses conflitos nutrição importante para o narcotráfico que por sua vez retroalimenta, fortalece e amplifica o projeto de globalização. Os cinturões e bolsões de pobreza e marginalidade são os setores privilegiados de recrutamento de consumidores, de narcotraficantes e de outras formas de criminalidade e violência. 
As repercussões da crise econômica dos anos 70 e a adoção dos padrões de acumulação neoliberais na América Latina, principalmente nos países mais periféricos, que vivem pesadamente do setor primário da economia são inúmeras. Os preços das matérias primas caíram durante a crise. Sem conseguir acesso à economia os agricultores gradualmente trocaram a cultura de algodão e outros produtos agrícolas pela narcocultura, principalmente nos países andinos (Kaplan 1997). A narcocultura é de um lado, conhecida, pelos hábitos culturais locais. De outro lado, foi se consolidando pela conveniência do dinheiro "magicamente" conveniente à especulação, uma vez que pode ser lavado e transformado em bens limpos com a facilidade que os bancos necessitam para girar para o capital (Coggiola 2001).

Conforme Queiroz, Salum (1997), o Brasil foi o último país latinoamericano a adotar o ideário do neoliberalismo, submetendo-se ao processo de globalização. O neoliberalismo funda-se na desigualdade, que estimulando a "saudável" competição de mercado desresponsabiliza o Estado em prover direitos de cidadania. $O$ desemprego cresceu assustadoramente nas últimas décadas com a desregulamentação das atividades econômicas e sociais pelo Estado e a insegurança penetrou no cotidiano das pessoas, famílias e grupos sociais pela reversão de alguns padrões de proteção social adquiridos ao longo do processo civilizatório.

Essa análise estrutural tem poder para explicar porque a partir principalmente da década de 70 e 80 há uma disseminação do consumo de drogas em todo o mundo e particularmente no Brasil, uma vez que a droga passa a uma condição clara de mercadoria cujo consumo pode "atender" a diferentes finalidades, que vão desde o aplacamento de angústias provenientes da vida insegura em que os mecanismos de confiança estão balançados à reprodução de valores que contemporaneamente fornecem as bases para a vida em sociedade - competição, individualismo e hedonismo (Soares 1997).

Para entender como, em contextos específicos, pode haver um consumo de drogas prejudicial, no entanto, é preciso mergulhar nas condições 
particulares ou nos contextos específicos em que esse consumo se realiza, compreendendo quem fala, de que lugar fala e o que diz (Soares 1997).

\subsection{A juventude universitária e suas marcas culturais}

O presente estudo tem como foco o grupo de universitários, especificamente na Universidade de São Paulo e no Conjunto Residencial da USP.

A população universitária brasileira é formada primordialmente por jovens. Os dados do perfil sócio-econômico dos moradores do CRUSPGraduação, São Paulo; 1999 evidenciam esse fenômeno apontando que 37\% dos moradores do CRUSP tem entre 22 e 24 anos e que $90 \%$ dos moradores estão na faixa etária que vai dos 17 aos 28 anos. Além disso, esses alunos em sua maioria têm como renda as chamadas "bolsas", que são uma ajuda de custo. Assim, o grupo estudado se caracteriza por ser jovem, de famílias compostas por trabalhadores assalariados, em ocupações semiqualificadas ou não-qualificadas, que recebem remunerações insuficientes para a reprodução da vida social, mas que conseguiram manter seus filhos na escola em busca de uma formação profissional para se inserir no mercado de trabalho.

Uma pergunta que surge dessa constatação é o que é ser jovem? Mas para responder a essa pergunta se faz necessário percorrer o caminho histórico que levou à formação da juventude enquanto categoria em destaque na sociedade ocidental moderna, sendo necessário que ela seja compreendida em sua complexidade e determinação histórica (Spósito 1992).

Um dos elementos fundamentais para essa compreensão é a adolescência, considerada por diversas correntes da história, da sociologia e da psicologia social, das quais nos valemos, uma primeira fase da juventude, fruto da organização social pós revolução industrial. Assim, embora atualmente haja uma naturalização das características da adolescência e das dificuldades 
vividas por pais e filhos nessa etapa da vida, essas formulações não se confirmam ao se realizar uma leitura histórica sobre esse fenômeno. Pois será somente a partir do século XX que a adolescência começará a despontar no cenário social, os adultos passarão a se preocupar em saber o que eles pensam e surgirão algumas pesquisas sobre essa faixa etária (Áries 1981).

Abramo (1994) ressalta que com a industrialização aparece a necessidade de preparar o jovem para o trabalho, ou seja, aparecem novas exigências impostas pela nova condição de trabalho e pelo desenvolvimento tecnológico. A escolarização deixa de ser exclusividade das camadas sociais mais abastadas. Com isso, o tempo necessário para a entrada no mundo adulto se alarga, os jovens têm uma maior convivência, unem-se enquanto grupo, passam a descobrir características comuns e assim se firmam perante a sociedade.

"A adolescência na sociedade moderna é resultado do desenvolvimento industrial que torna essa transição para a idade adulta muito mais complicada" (Eisenstadt apud Soares 1997 p.138).

Segundo Áries (1981) será após a primeira guerra mundial, quando os jovens se opõem às antigas gerações, questionando as mortes ocorridas devido à guerra e aos valores vigentes, que surgirá a consciência da juventude, inicialmente como um sentimento de ex-combatentes.

A adolescência que não era considerada até então, passa a ser uma fase em que todos querem chegar e dela não querem sair. A juventude se torna depositária das expectativas de mudanças na sociedade européia. Ao mesmo tempo em que começa a haver uma exaltação da juventude há um sentimento inverso em relação à velhice (Áries 1981). As questões relativas à juventude assumem na sociedade moderna uma proporção muito grande. Isso porque esse é o tempo de ser jovem. A velhice perdeu seu status de sabedoria e autoridade (Morin 1997). 
Embora, atualmente, a adolescência ou a juventude sejam caracterizadas como um período de transição da infância para a vida adulta e de mudança de pertença de grupo as conseqüências e a intensidade dos fenômenos que acontecem nesse período variam de acordo com a cultura e a classe social (Lapassade 1975).

Segundo Soares (1997) embora fatores econômicos, culturais e psicológicos possam convergir para determinar o comportamento dos adolescentes, a condição de classe de suas famílias é preponderante. O que leva a supor, de acordo com Novaes (2000), que não existe a juventude e sim várias juventudes que convivem num mesmo espaço social e temporal. Dessa forma, o termo juventude torna - se vazio de significado (Novaes 2000).

"Preferimos falar em adolescentes que se diferenciam pela sua história de vida de acordo com sua inserção sócio-econômica e seu desenvolvimento psicológico particular num dado contexto histórico e cultural" (Soares 1997 p.37).

Assim, o fenômeno universal se restringe à puberdade que se caracteriza por mudanças que acontecem no corpo devido a um processo de amadurecimento .

No que se refere à chamada crise da adolescência Lewin (apud Lapassade 1975) assinala que essa decorre de uma organização social que coloca o adolescente no lugar de marginal. Marginal compreendido como aquele que não tem seu próprio espaço, que está numa terra de ninguém (....) "é colocado no ponto de intersecção de dois grupos [criança e adulto]: não pode determinar exatamente o grupo a que pertence" (p. 163). É nessa fase de transição que para Morin (1997) se vive uma grande contradição que é a procura ao mesmo tempo da autenticidade e da integração à sociedade.

Lapassade (1975) cita Marx para esclarecer que a entrada na vida adulta se dá pelo trabalho e que as formas de inserção e o significado deste variam de acordo com a classe a que pertence o jovem, existindo, portanto, uma 
personalidade de classe. Estes autores referem ainda que deve ser dada a devida importância para a práxis para que se possa compreender a entrada na vida adulta.

Além disso, a escolha profissional também está vinculada e é limitada pela classe social a que pertence o jovem. Isso no que se refere tanto às condições econômicas quanto culturais. Os fatores culturais se apresentam tanto na escolha da carreira como no transcorrer do curso, pois os jovens de classe mais baixa não encontram eco nem em sua família, nem em seu grupo de amigos para o aprendizado proporcionado em seu curso. Disso pode decorrer um distanciamento devido às mudanças que se dão em decorrência do aprendizado (Lapassade 1975).

No Brasil será a partir da década de 60 que os estratos médios da sociedade terão maior acesso a Universidade (Foracchi 1972), pois até então este era um privilégio das classes mais abastadas. Em estudo realizado por Foracchi (1972) com estudantes da Universidade de São Paulo em 1963, pôdese constatar que o estudante universitário representava um encargo para a família e que a formação universitária representaria um investimento para alcançar uma ascensão social. Em muitos casos, nesse estudo, esses estudantes eram a primeira geração universitária na família.

Esse fenômeno apontado por Foracchi (1972) aconteceu mundialmente segundo Hobsbawm (1995), pois embora a corrida dos jovens para as universidades tenha ocorrido a partir da década de cinqüenta foi somente a partir da década de sessenta que os estudantes obtiveram expressão política e social. Em alguns países o número de universitários quadruplicou. A razão para tal fenômeno está no fato de que a economia moderna exigia dos profissionais um preparo específico obtido na universidade. Os pais, em vários países do mundo, faziam verdadeiros sacrifícios para manter seus filhos na universidade pois isso significava a possibilidade de ascensão social na década de $70 \mathrm{e}$ nesse período o mercado podia absorver boa parte dos formados.

Segundo Abramo (1994) às modificações no mercado de trabalho nos anos 70 e 80 acompanharam mudanças na vida dos jovens de classe média no 
Brasil. O movimento estudantil que foi protagonista das mudanças sociais entrou em crise nessa década e perdeu força, poder e deixou de ser símbolo da categoria juvenil.

No período mais crítico da ditadura brasileira a universidade era um dos únicos espaços de crítica ao regime vigente. Para se ter uma idéia eventos culturais de diversas ordens só podiam acontecer na universidade por causa da censura existente, sendo que os jovens universitários e os intelectuais eram os principais responsáveis pelas produções culturais alternativas (que se opunham a produzida ou incentivada pelo sistema) (Abramo 1994).

Será com a luta contra a ditadura e pela conquista das liberdades democráticas que o espaço universitário se firmará como um lugar de sociabilidade e construção de identidades positivas em torno da figura do estudante (Abramo 1994).

Com a abertura política o cenário todo se altera e há o aparecimento de novos espaços de atuação política e cultural. A partir de então há uma alteração na configuração do papel social da universidade e há também um esvaziamento dos movimentos estudantis, suas lideranças tiveram dificuldade em se adaptar a nova conjuntura. (Abramo 1994).

Essas mudanças levaram a universidade e o movimento estudantil a deixarem de ser um espaço de vivência social e cultural. Os jovens universitários passaram a buscar outros espaços de atuação ligados principalmente aos movimentos culturais (Abramo 1994).

Além disso, fazer um curso universitário vai deixando de ser um símbolo de ascensão social e portanto garantia de bons salários e de uma melhor capacitação profissional (Abramo 1994).

Nos últimos anos do século $\mathrm{XX}$ assistimos a um maior acesso das classes mais baixas às instituições de ensino superior, mas mesmo assim essas não perderam seu caráter elitista (Salum 2001). O acesso à universidade está restrito a $10 \%$ da população da faixa etária apropriada (Ristoff apud Salum 2001). 
No Brasil, nos últimos anos, verifica-se também um aumento das instituições particulares de ensino superior com apoio governamental sendo que a mesma regra não é seguida no que se refere às universidades públicas (Salum 2001).

\subsection{Bases para pensar a prevenção}

Ao abordar o uso de drogas e as alternativas sociais propostas para responder ao problema, encontramos o tratamento, a prevenção, a repressão ao tráfico e as leis. O tratamento é a proposta médica clássica aos problemas instalados. A prevenção se apresenta como uma alternativa para atuar antes que os problemas se instalem ou se agravem e que com o passar dos anos conquistou certa unanimidade sobre sua importância nesta área. Mas, mesmo entre os profissionais que atuam na área de prevenção, existem muitas divergências sobre o objetivo da prevenção, a forma de realizá-la, as idéias que devem ser transmitidas e a quem compete a coordenação e avaliação.

O resgate da história da prevenção ao uso de drogas nos ajuda a compreender algumas das dificuldades vividas hoje nessa área.

Inicialmente atividades preventivas consistiam em repressão e fiscalização, com o objetivo de reduzir o consumo das drogas ilícitas e controlar todo o processo de produção, incluídas a fonte, a comercialização e o consumo. Mas essas medidas se mostraram ineficientes, pois não foram capazes de cumprir seus objetivos, ao invés disso o mundo assistia a um aumento do consumo e da produção. ${ }^{3}$

Diante dessa situação, em 1970, a UNESCO convidou profissionais de diversos países para discutir o tema prevenção ao uso de drogas. Com a

${ }^{3} \mathrm{O}$ fracasso do sistema repressivo, relativo às drogas, tem sido discutido por vários autores entre eles: Barata (1994), Karan (1997) e Sá (1993). Estes autores, ligados a área do direito, demonstram a necessidade de ampliação da discussão sobre os efeitos negativos da criminalização das condutas relativas ao uso de algumas drogas psicotrópicas. 
discussão concluiutse que a prevenção deveria ter centro na educação. Esta conclusão foi um marco no que se refere às perspectivas de trabalho na área (Bucher 1989).

No entanto, num primeiro momento, a educação preventiva foi transformada em ação através da realização de campanhas veiculadas na imprensa e pela inserção do tema no currículo escolar, com o único objetivo de promover a abstinência. As informações disseminadas eram alarmistas e procuravam gerar medo sobre as conseqüências maléficas do uso de qualquer substância. Este tipo de abordagem logo caiu em descrédito, pois a disseminação do medo extinguiu a possibilidade de diálogo entre a escola e os alunos, a primeira passando a ser vista como repressiva e ameaçadora (Bucher 1989, Carlini-Cotrin 1992).

Avaliações fundamentadas em metodologias consagradas cientificamente, realizadas em vários países, constataram que a educação preventiva que dissemina informações alarmistas gera curiosidade e desejo de experimentar alguma droga. A constatação do fracasso desse modelo reforça a necessidade de desenvolver novas concepções para se abordar o tema sendo estas divergentes e contraditórias (Bucher 1992).

A concepção de prevenção que se apresenta em franca oposição à repressiva também é chamada de educação preventiva, no entanto, parte de pressupostos completamente diferentes, tendo como preocupação principal o investimento na auto-realização, na auto-estima e no desenvolvimento do senso de responsabilidade em relação à própria vida. $\mathrm{Na}$ formação ao invés de exclusivamente na informação.

"A educação para ter um alcance preventivo deve situar-se num espaço mais amplo: o uso de drogas não deve ser visto como aspecto isolado da vida social, mas tem que ser inserido num contexto geral da saúde, da convivência social e dos valores" (Bucher 1989 p 20). 
Para Bucher (1992) e Carlini-Cotrim (1992) não existe prevenção neutra, qualquer modelo adotado está permeado por uma forma de compreender o ser humano, sua vida em sociedade, as contradições presentes nas relações humanas e numa significação valorativa atribuída ao uso de drogas. Para ele, embora existam diversos modelos de prevenção, estes podem ser agrupados em duas concepções fundamentais: uma atrelada ao modelo repressivo, mais ou menos evidente e outra ao modelo educativo.

$\mathrm{Na}$ concepção repressiva dominante as drogas são percebidas como o mal que precisa ser eliminado para que a sociedade viva em paz, os usuários são vistos como frágeis seres que precisam ser "educados" para se adequarem às normas sociais (Velho 1999). O tráfico e os problemas advindos do uso e da dependência são percebidos como os maiores problemas atuais. Não se percebe como afirma Barata, (1994) que a produção não está determinada pelas necessidades nem do produtor nem do consumidor e sim pela lógica do mercado cujo principal objetivo é a obtenção de lucro.

$\mathrm{Na}$ concepção educativa, o uso de drogas é compreendido como um fenômeno da sociedade, uma resposta ao "mal estar" causado pelo modos vivendi atual. Este não é o único e nem o maior problema, pois a subnutrição a corrupção, a falta de emprego e de perspectiva de futuro aos jovens são tão importantes quanto aqueles relacionados às drogas. O que se pode concluir é que o uso de drogas e o tráfico são um problema sócio-político de grandes dimensões, tanto nacional como internacionalmente, mas que culpabilizar estas substâncias por todos os flagelos da sociedade atual colabora para que outras discussões mais amplas não se dêem. A compreensão do significado atual do uso de drogas só é possível a partir da discussão do contexto social, político e econômico (Birmam 2000, Bucher 1992, Soares 1997).

Viver numa sociedade onde não existem mais utopias políticas e o ideal de felicidade em que os homens viveriam em condições de igualdade, independentemente de suas crenças religiosas, cor de pele e origem social deixou de ser um ideal comum, substituído pela lógica do esforço individual e acúmulo de dinheiro e bens, proporcionou para muitos, a busca de amparo na 
religião e, para os incrédulos, em substâncias que proporcionam estados nirvânicos. É neste contexto histórico que se constrói o império das drogas (Birman 2000).

Mas, os problemas relacionados ao uso de drogas não ocorrem com todas as pessoas, nem mesmo com todos os jovens que as experimentam. Isto se deve ao fato de que existem especificidades individuais, psicológicas e talvez biológicas que transformam 0 uso de substâncias que alteram a consciência, as emoções e as sensações, em única alternativa de alívio ao sofrimento e de prazer (Birmam 2000).

Essa constatação da realidade tem concordância com a concepção teórica de que estes problemas ocorrem devido a complexa relação entre três fatores: o indivíduo, a droga e a sociedade. Estão implicados então: um indivíduo dotado de personalidade, crenças e valores, inserido de uma dada forma na sociedade, o produto droga, suas características e efeitos no organismo e o contexto sócio-cultural que cerca o momento em que se dá o encontro do indivíduo e da droga (Soares 1997, Bucher 1989).

Portanto, para que se possa fazer um programa de prevenção se faz necessário levar em conta todos os aspectos envolvidos, explicitando a que tipo de concepção o programa estará atrelado. Autores como Sá (1993), Carlini (1990) e Soares (1997) postulam que não existem programas preventivos universais e que não se deve adaptar programas provenientes de realidades distintas.

Recomenda-se conhecer a realidade da população com a qual se pretende trabalhar sob vários aspectos, entre eles a forma de inserção social, a cultura específica, os valores e as drogas mais usadas (Carlini e col 1990). Além disso, é importante que desde o início se esclareça qual o objetivo do trabalho, para que este possa ser avaliado e para que os participantes possam escolher se querem ou não participar.

Um dos problemas evidentes no modelo dominante de prevenção, segundo Soares (1997), é que este mascara as diferenças de inserção social, 
apresenta o dependente como único responsável por sua condição e não discute os determinantes sociais presentes na configuração desta problemática.

Para que se possa realizar um programa de prevenção comprometido com o respeito pelas pessoas individualmente e ao grupo a que pertencem deve-se ter, assim como assinala Soares (1997), como objetivo geral a vinculação destas duas dimensões: a individual relacionada à formação do cidadão crítico e a outra relacionada à organização social que deve proporcionar os meios para que esta existência se efetive.

Um outro aspecto que nos auxilia a compreender as dificuldades relativas a mudanças de atitudes sobre como abordar o tema drogas no cenário atual brasileiro, se refere a como são tratadas oficialmente essas questões pela atual Política Nacional Antidrogas (PNAD), lançada em 11 de dezembro de 2001, pelo presidente Fernando Henrique Cardoso.

Essa política apresenta os pressupostos teóricos, os objetivos gerais e as diretrizes para prevenção, tratamento, recuperação e inserção social, redução de danos sociais e de saúde, tráfico, estudos, pesquisas e avaliação sobre drogas em território nacional.

$O$ texto da PNAD em sua introdução descreve o problema do uso indevido de drogas como "(...) uma ameaça à humanidade e à estabilidade das estruturas e valores políticos, econômicos, sociais e culturais de todos os Estados e sociedades". Além disso, apresenta como pressuposto a construção de uma sociedade livre do uso de drogas ilícitas e do abuso das lícitas.

Em seu aspecto geral, o texto apresenta a idéia de que o governo e a sociedade devem travar uma luta contra as drogas, como se as substâncias fossem um mal em si, e apresenta os problemas relacionados ao uso como descolados da realidade social, econômica e política atual do país.

Há uma preocupação evidente com a redução da demanda, termo que aparece em itens que versam sobre a prevenção e sobre a repressão. Pode-se verificar neste documento alguns antagonismos, pois ao mesmo tempo em que trata quase que exclusivamente sobre as drogas ilícitas, usa como referência os dados do Centro Brasileiro de Estudos sobre Drogas (CEBRID) que assinalam 
que as drogas mais usadas por estudantes são as lícitas (álcool, tabaco, solventes e anfetaminas).

Esta política é um bom exemplo de como se reproduz a ideologia dominante. Esta entendida como:

“(..) idéias e representações [que] serão produzidas e difundidas pela classe dominante para legitimar e assegurar seu poder econômico, social e político. Por este motivo, essas idéias ou representações tenderão a esconder dos homens o modo real como suas relações sociais foram produzidas e a origem das formas sociais de exploração econômica e de dominação política. Este ocultamento da realidade social chama-se ideologia" (Chauí 2001 p23).

Nos auxiliam na compreensão da importância da análise deste material, as considerações feitas por Barata (1994) para explicar a permanência da visão criminalizadora relativa a qualquer forma de uso das drogas ilícitas. Ele nos apresenta o teorema de Thomas, muito presente na sociologia moderna, que postula que quando se sustenta uma determinada imagem da realidade, esta imagem produz efeitos reais. No que se refere às drogas a reação social criminalizadora produz por si só a realidade que a legitima.

Um outro aspecto levantado pelo autor é o fato de haver uma homogeinização das informações transmitidas pelos meios de comunicação no que se refere ao tema drogas. Parte-se da idéia de que a relação entre os meios de comunicação e os expectadores é de condicionamento recíproco. Os meios de comunicação seguem:

"Ativando e atualizando tendências que já existem no público, e oferecendo aos indivíduos isolados um elemento massivo de agregação e de consenso, afetam não apenas a imagem da realidade, mas a própria realidade".(Barata 1994 p. 25). 
A substituição das experiências diretas pela experiência do espetáculo (assistido na TV) aumenta a distância da imagem diante da realidade com relação à experiência cotidiana das pessoas. Esta estrutura comunicativa favorece a manutenção das idéias dominantes e do "status quo" da política de drogas.

Dessa forma evidencia-se a responsabilidade de diferentes setores da sociedade na estigmatização dos usuários e dependentes de droga e na criação de fenômenos que passam a ser apresentados como naturais.

Segundo Barata (1994) o problema atual das drogas está relacionado às contradições produzidas no sistema de relações sociais e de produção, pela distorção relativa ao desenvolvimento equilibrado das necessidades reais do homem e da produção de recursos para satisfazê-las nas diferentes culturas.

Para compreender o que significa na cultura brasileira contemporânea, "ser drogado", recorremos a Velho (1999), que propõe a análise do significado de ser "drogado" a partir do que chamou de categorias de acusação. $O$ autor parte da idéia de que a vida social é um processo contraditório e complexo e que a realidade é permanentemente negociada pelos atores sociais, e que os conflitos não tem caráter catastrófico, mas são fenômenos que precisam ser estudados. Segundo este autor, há uma categoria abrangente a de "doente mental" e desta deriva a de "drogado" sendo esta uma categoria totalizadora, ou seja, contamina toda a vida do individuo acusado estigmatizando-o de forma definitiva, com acusações que atacam a identidade do acusado de forma radical. O drogado é identificado como doente, um ser fraco, sem vontade e manipulado pelos traficantes. O rótulo de drogado serve para explicar qualquer problema vivido pelo indivíduo e dependendo do contexto assume uma dimensão política:

"O fato dos acusados serem moralmente nocivos segundo o discurso oficial, pois tem hábitos costumes desviantes, acaba por transforma-los em 
ameaça ao "status quo", logo em problema político" (Velho 1999 p 60).

O autor destaca que no tipo de análise que propõe deve-se discutir o grau de consciência dos envolvidos no processo acusatório, pois estamos falando de emoções e não apenas de interesses. 


\section{Objetivo e finalidade}

\subsection{Objetivo}

O presente trabalho teve como objetivo conhecer e analisar o discurso dos moradores sobre os processos de socialização no Conjunto Residencial da USP - CRUSP destacando o consumo de drogas.

A importância desse trabalho reside principalmente em dois fatos: em primeiro lugar, na ausência de trabalhos científicos sobre moradia estudantil e, em segundo lugar, na condição da moradia de se constituir como um espaço de socialização importante, uma vez que os alunos dela se valem, em muitos casos, durante todo o tempo que levam para concluir o curso (varia de quatro a cinco anos) muitos só podendo visitar a família esporadicamente (devido a problemas financeiros e distância). A moradia é composta por jovens que estão saindo de casa pela primeira vez, são em sua maioria pobres e estão vivenciando um "mundo" completamente novo para eles.

O pressuposto é de que essa combinação de fatores traz uma série de dificuldades de adaptação à nova vida que aliadas ao fato da universidade relutar em assumir a moradia como um espaço de suma importância na democratização do acesso à universidade pode produzir sintomas de um certo mal estar na atualidade (Birmam, 2000) como o consumo de drogas e a depressão.

Faz se necessário elucidar e discutir os problemas para que alternativas sejam encontradas e para que se possa aperfeiçoar os mecanismos existentes de viabilização de uma vida estudantil plena e saudável. 


\subsection{Finalidade}

Este estudo procurou reconstruir a história do CRUSP com a finalidade de valorizar a existência da moradia e lutar, assim como no passado, para que sejam implementadas melhorias.

$\mathrm{Na}$ mesma direção, o conhecimento sobre o significado de morar no CRUSP para os alunos, que remete aos aspectos positivos e negativos da moradia deve servir aos órgãos competentes como diretrizes para elaboração de políticas para a moradia e aos próprios alunos como possibilidade de conhecer os diferentes pontos de vista presentes no CRUSP.

Além disso, ao se discutir o tema do consumo de drogas com os moradores pôde-se compreender mais amplamente como os alunos percebem o uso e os usuários de drogas e suas sugestões para prevenção a um consumo que pode ser prejudicial aos estudantes. 


\section{Procedimentos metodológicos}

O presente trabalho utilizar-se-á da abordagem qualitativa de pesquisa na medida em que refere-se a um objeto que, por sua natureza, é um objeto das ciências sociais, pois trata-se de um grupo de alunos de graduação da USP, vivendo num contexto específico - o da residência estudantil pertencente a uma determinada classe social, no momento histórico contemporâneo, com uma dada vivência sobre o uso de drogas.

Trata-se de um estudo de natureza exploratória que procurará descrever alguns aspectos de realidade específica da moradia, analisando-os e levantando novas hipóteses a serem investigadas.

Minayo (1999) reafirma a potência da pesquisa de corte qualitativo para dar conta do objeto das ciências sociais, elucidando a complexidade das relações sociais que se estabelecem entre indivíduos "em determinada condição social pertencente a determinado grupo social ou classe com suas crenças, valores e significados" (Minayo, 1999, p.22).

$\mathrm{Na}$ pesquisa qualitativa existem algumas propostas operacionais para organização e análise do material coletado. Neste trabalho, o procedimento metodológico que serviu de base para a coleta e organização do material proveniente das entrevistas é denominado "Discurso do Sujeito Coletivo" (DSC).

Segundo Lefévre, a proposta é que tanto através de entrevistas, quanto de artigos de jornal, revista, ou literatura se possa captar os diversos discursos, ou seja, diversas formas de compreensão de uma temática presentes num grupo específico. Nessa compreensão, os discursos são vistos como histórica e socialmente determinados, o que condiz com as preocupações deste trabalho.

O DSC é, portanto, um conjunto de procedimentos metodológicos que visa organizar o material verbal em forma de discursos síntese que expressam as diferentes idéias presentes em um determinado grupo. Parte-se do 
pressuposto de que o pensamento individual se expressa em formato de discurso, e que por sua vez, esse discurso é compartilhado por um grupo.

Portanto, para se conhecer o que um dado grupo social pensa sobre determinado tema faz-se necessário acessar os discursos individuais, agrupando-os por semelhança ou complementaridade.

O início das entrevistas se deu após a aprovação do Comitê de Ética em Pesquisa da Escola de Enfermagem da USP (anexo 1) e da autorização da COSEAS - Coordenadoria de Assistência Social (anexo 2) que gerencia o CRUSP.

Não foi possível discutir o projeto com a representação dos alunos moradores do CRUSP (AMORCRUSP), embora tivesse sido procurada por diversas vezes.

\subsection{Coleta de dados}

A técnica de entrevista foi escolhida devido à sua aplicabilidade nos trabalhos científicos qualitativos, sendo uma das formas mais utilizadas para se obter informações que permitam aprofundar as diferentes opiniões e crenças dos entrevistados sobre um determinado assunto (Minayo 1994, Lefèvre 2000).

"A entrevista produz sempre uma interpretação daquele que relata, trabalhando na própria subjetividade a objetividade do real" (Schraiber 1994 p-65)

As entrevistas foram individuais e semi-estruturadas, realizadas após conversa com o entrevistado, na qual se apresentou o objetivo, o projeto e as autorizações para a realização da pesquisa. As entrevistas foram gravadas e se iniciaram somente após a assinatura do Termo de Consentimento Livre e 
Esclarecido (anexo 3). A maioria das entrevistas foi realizada no CRUSP, mas houve casos em que ocorreu na faculdade, em uma sala específica na Escola Politécnica liberada para esse fim e até mesmo em banco de jardim na USP.

O roteiro de perguntas foi elaborado de forma a se obter a caracterização sócio-demográfica do aluno, seu conhecimento da história do CRUSP, seu sentimento sobre a moradia, sua participação em atividades de lazer, sua opinião sobre: quem usa drogas, o uso de drogas no CRUSP, a idéia presente na USP de que o CRUSP é um ambiente livre e que propicia o uso de drogas e quais as suas sugestões sobre o que pode ser feito - prevenção (anexo 4).

$O$ enunciado de algumas perguntas $\left(n^{\circ} 3\right.$ e 6 ) sofreu alterações durante $o$ processo de realização das entrevistas, o que condiz com uma idéia presente na pesquisa qualitativa de que o roteiro freqüentemente será atualizado a partir do diálogo estabelecido entre pesquisador e os pesquisados (Schraiber, 1995).

Por entender-se, em primeiro lugar, que a pesquisa qualitativa constitui um processo de aperfeiçoamento que depende, entre outras coisas, da relação entre entrevistador e sujeito da pesquisa, e, em segundo lugar, que o objeto deste trabalho está centrado nas particularidades do CRUSP, não foram realizadas entrevistas piloto, tomando-se as mudanças que por ventura se fizessem necessárias ao roteiro, como parte do processo de aprimoramento do estudo (Demartine, 2001).

De maneira geral, o número de pessoas a serem entrevistadas na pesquisa qualitativa (amostra) só é definido a partir: da obtenção de dados que de fato correspondem ao objeto empírico e do processo de reincidência das informações que devem, por outro lado, permitir um certo grau de diversificação presente num grupo determinado (Minayo, 1994). No caso particular do discurso do sujeito coletivo, a técnica vem estipulando, a partir da experiência acumulada, o número de 20 , quando então a probabilidade de mudanças no discurso é muito pequena (Lefèvre, 2000).

Assim, foram realizadas 20 entrevistas, pedindo-se sempre aos entrevistados que indicassem pelo menos dois colegas de outros cursos, moradores do CRUSP. Essa técnica, conhecida como snowball, tem sido 
indicada, por possibilitar melhor recepção e disponibilidade do entrevistado em relação a pesquisa pois permite que o pesquisador e entrevistado sejam de alguma forma apresentados (Becker 1994, Nappo 1999).

As duas primeiras entrevistadas foram alunas da Escola de Enfermagem com quem se mantinha algum contato. As entrevistas posteriores com os alunos indicados foram marcadas por contato telefônico. Houve muitas dificuldades na marcação de horários, uma vez que, na maioria das vezes, os estudantes trabalham e estudam, ocasionando remarcações. Esse processo se repetiu até a entrevista $n^{\circ} .12$ e durou aproximadamente dois meses. Por causa disso mudou-se a estratégia de contato com os alunos. A pesquisadora foi até 0 CRUSP em dois finais de semana (um sábado e um domingo), realizando as entrevistas a partir da consulta a estudantes que estavam no corredor, nos apartamentos, indagando, e solicitando a um entrevistado que indicasse um colega que estivesse no CRUSP naquele dia. Assim foram realizadas as 8 entrevistas que faltavam.

Durante todo esse processo houve uma preocupação em entrevistar alunos que moram nos diferentes blocos da graduação (foram entrevistados 4 alunos por bloco), sendo metade de cada sexo, em cursos diferentes ( $40 \%$ dos entrevistados estão fazendo algum curso na FFLCH (Faculdade de Filosofia Letrtas e Ciências Humanas da USP) pois segundo o perfil dos moradores do CRUSP elaborado pela COSEAS essa é a proporção dessa unidade no total de moradores). Esses procedimentos se deram devido a importância de se obter um grupo heterogêneo de entrevistados. Pois, embora o número de pessoas entrevistadas se apresenta como uma questão fundamental para a pesquisa qualitativa, para a construção dos Discursos do Sujeito Coletivo (DSC), que pretende abarcar o universo de idéias, crenças, valores presentes sobre determinado assunto, numa dada comunidade o mais importante é que a amostra seja diversificada.

As entrevistas foram transcritas literalmente (encontram-se na íntegra no CD rom na contra capa desse trabalho) para que após análise do material, se obtenha os Discursos do Sujeito Coletivo. O interesse por estes discursos se 
dá, pois parte-se do pressuposto que "o pensamento coletivo pode ser visto como um conjunto de discursos sobre um dado tema" (Lefévre 2002 p. 11).

\subsection{Caracterização dos alunos do Conjunto Residencial da Universidade de São Paulo - CRUSP}

O número total de moradores oficialmente cadastrados, atualmente, é de 1.348 (graduação 970 e pós-graduação 378). O CRUSP apresenta 7 blocos, de A-G, com 6 andares e 11 apartamentos por andar cada apartamento foi dimensionado para 3 estudantes. Dos 7 blocos, 5 destinam-se a alunos de graduação e dois a alunos de pós-graduação.

A moradia é gratuita e destina-se a alunos de graduação e pósgraduação da USP, regularmente matriculados que passam por processo seletivo no início de cada ano. Esse processo é classificatório e baseado em uma avaliação do nível sócio-econômico do aluno, feita pelas assistentes sociais da Divisão de Promoção Social (DPS). No final de cada ano é feita a reavaliação dos alunos.

Nos blocos da graduação há uma cozinha por andar, uma lavanderia por bloco. Nos blocos existem áreas coletivas como: sala de vídeo e sala pró-aluno com 22 computadores disponíveis para todos os moradores. Todos os blocos possuem uma portaria que tem a função de fazer a segurança e receber as ligações telefônicas para os moradores. A manutenção dos prédios é feita pela Coordenadoria de Assistência Social da USP (COSEAS).

A atualização do perfil sócio econômico dos alunos de graduação, moradores do CRUSP é elaborada pela equipe de assistentes sociais da COSEAS. ${ }^{4}$ No documento a que tivemos acesso não constava o número bruto

\footnotetext{
4 Os dados apresentados referem -se a reavaliação de 590 alunos, em documento interno da COSEAS. Coordenadoria de Assistência Social - Perfil sócio-econômico dos moradores do CRUSP- Graduação. São Paulo; 1999.
} 
dos alunos para cada categoria apresentada.

Quadro 1 - Distribuição dos alunos de graduação selecionados para morar no CRUSP, segundo a caracterização sócio-demográfica. Perfil sócioeconômico dos moradores do CRUSP- Graduação. São Paulo; 1999

\begin{tabular}{|c|c|c|c|c|c|c|}
\hline \multicolumn{7}{|c|}{ Idade } \\
\hline $17-21$ & $22-24$ & $25-28$ & $29-35$ & \multicolumn{2}{|c|}{ Acima de 35} & Total \\
\hline $26 \%$ & $37 \%$ & $27 \%$ & $8 \%$ & \multicolumn{2}{|c|}{$2 \%$} & $100 \%$ \\
\hline \multicolumn{4}{|c|}{ Estado civil } & \multicolumn{3}{|c|}{ Filhos } \\
\hline Solteiro & Casado & Separado & Total & Sim & Não & Total \\
\hline $96 \%$ & $3 \%$ & $1 \%$ & $100 \%$ & $5 \%$ & $95 \%$ & $100 \%$ \\
\hline \multicolumn{7}{|c|}{ Fonte de renda $^{*}$} \\
\hline estágio & $\begin{array}{l}\text { bolsa de } \\
\text { estudos }\end{array}$ & família & Outras fontes & \multicolumn{2}{|c|}{ salário } & Total \\
\hline $27 \%$ & $27 \%$ & $25 \%$ & $13 \%$ & \multicolumn{2}{|c|}{$8 \%$} & $100 \%$ \\
\hline \multicolumn{7}{|c|}{ Renda ( salário mínimo) ${ }^{\star \star}$} \\
\hline \multicolumn{2}{|c|}{$\mathrm{R} \$ 151,00$} & $\begin{array}{l}\$ 151,00 \text { á } \\
R \$ 302,00\end{array}$ & $\begin{array}{c}R \$ 302,00 \text { à } \\
R \$ 453,00\end{array}$ & \multicolumn{2}{|c|}{$\mathrm{R} \$ 453,00$} & Total \\
\hline $30 \%$ & \multicolumn{2}{|r|}{$36 \%$} & $23 \%$ & \multicolumn{2}{|c|}{$11 \%$} & $100 \%$ \\
\hline
\end{tabular}

No quadro 1 verifica-se que a maioria dos alunos moradores do CRUSP encontra-se na faixa de 22 a 24 anos (37\%). Também a maioria dos moradores é solteira (96\%) e sem filhos (95\%). No que se refere a origem da renda nota-se que a maioria tem bolsa de estudo - inclui-se aqui o estágio - (54\%) e ganha entre um e dois salários mínimos (89\%). 


\section{Quadro 2 - Distribuição dos alunos de graduação selecionados para morar no CRUSP, segundo a caracterização do curso. Perfil sócio-econômico dos moradores do CRUSP- Graduação. São Paulo; 1999}

\begin{tabular}{|c|c|c|c|c|c|c|c|c|c|c|}
\hline \multicolumn{11}{|c|}{ Curso } \\
\hline $\mathrm{FFLCH}$ & $\mathrm{ECA}$ & EP & IF & IME & EE & FEA & FCF & EEFE & FAU & subtotal \\
\hline $46 \%$ & $8 \%$ & $5 \%$ & $5 \%$ & $5 \%$ & $4 \%$ & $4 \%$ & $3 \%$ & $2 \%$ & $2 \%$ & $84 \%$ \\
\hline \multicolumn{11}{|c|}{ Curso } \\
\hline FE & FM & IAG & IB & $\mathbb{I Q}$ & IGC & FSP & $\mathrm{FO}$ & IP & FMVZ & total \\
\hline $2 \%$ & $2 \%$ & $2 \%$ & $2 \%$ & $2 \%$ & $2 \%$ & $1 \%$ & $1 \%$ & $1 \%$ & $1 \%$ & $100 \%$ \\
\hline \multicolumn{11}{|c|}{ Período } \\
\hline \multicolumn{2}{|c|}{ Matutino } & \multicolumn{2}{|c|}{ Diurno } & \multicolumn{2}{|c|}{ Noturno } & \multicolumn{2}{|c|}{ Integral } & \multicolumn{2}{|c|}{ Vespertino } & Total \\
\hline \multicolumn{2}{|c|}{$11 \%$} & \multicolumn{2}{|c|}{$9 \%$} & \multicolumn{2}{|c|}{$42 \%$} & \multicolumn{2}{|c|}{$28 \%$} & \multicolumn{2}{|c|}{$10 \%$} & $100 \%$ \\
\hline
\end{tabular}

${ }^{*}$ Cursos: FFLCH - Faculdade de Filosofia, Letras e Ciências Humanas, ECA - Escola de Comunicação e Arte, EP - Escola Politécnica, IF - Instituto de Física, IME Instituto de Matemática e Estatística, EE - Escola de Enfermagem, FEA - Faculdade de Economia, Administração e Contabilidade, FCF - Faculdade de Ciências Farmacêuticas, EEFE - Escola de Educação Física e Esporte, FAU - Faculdade de Arquitetura e Urbanismo, FE - Faculdade de Educação, FM - Faculdade de Medicina, IAG - Instituto Astronômico e Geofísico, IB - Instituto de Biociências, IQ Instituto de Química, IGc - Instituto de Geociências, FSP - Faculdade de Saúde Pública, FO Faculdade de Odontologia, IP - Instituto de Psicologia, FMVZ - Faculdade de Medicina Veterinária e Zootecnia.

No quadro 2 verifica-se que a maioria dos alunos está cursando a FFLCH (46\%), em período integral (28\%) ou noturno (42\%). 
Quadro 3 - Distribuição dos alunos de graduação selecionados para morar no CRUSP, segundo a caracterização sócio-demográfica de suas famílias. Perfil sócio-econômico dos moradores do CRUSP - Graduação. São Paulo, 1999.

\begin{tabular}{|lc|lc|}
\hline \multicolumn{2}{|c|}{ Situação ocupacional do pai } & \multicolumn{1}{c|}{ Situação ocupacional da mãe } \\
\hline Aposentado & $28 \%$ & Aposentada & $8 \%$ \\
\hline Autônomo & $27 \%$ & Autônoma & $12 \%$ \\
\hline Empregado & $18 \%$ & Empregada & $21 \%$ \\
\hline Falecido & $13 \%$ & Falecida & $5 \%$ \\
\hline Não consta & $7 \%$ & Não consta & $2 \%$ \\
\hline Desempregado & $6 \%$ & Desempregada & $2 \%$ \\
\hline Trabalho informal & $1 \%$ & Trabalho Informal & $2 \%$ \\
\hline--- & ---- & Trabalho doméstico & $48 \%$ \\
\hline Total & $100 \%$ & Aposentada & $100 \%$ \\
\hline
\end{tabular}

\begin{tabular}{|ccc|}
\hline & Grau de escolaridade & \\
\hline & Pai & Mãe \\
\hline $1^{\circ}$.grau incompleto & $38 \%$ & $37 \%$ \\
\hline $1^{\circ}$.grau completo & $17 \%$ & $17 \%$ \\
\hline $2^{\circ}$.grau incompleto & $4 \%$ & $5 \%$ \\
\hline $2^{\circ}$.grau completo & $13 \%$ & $17 \%$ \\
\hline Superior incompleto & $4 \%$ & $3 \%$ \\
\hline Superior & $12 \%$ & $12 \%$ \\
\hline Analfabeto & $3 \%$ & $6 \%$ \\
\hline Não consta & $7 \%$ & $2 \%$ \\
\hline Falecido & $2 \%$ & $1 \%$ \\
\hline Total & $100 \%$ & $100 \%$ \\
\hline
\end{tabular}

No quadro 3 nota-se que a maioria dos pais trabalha como autônomo (27\%) ou está aposentado (28\%) e que as mães majoritariamente exercem o trabalho doméstico e o cuidado da casa e da família (48\%). No que se refere a escolaridade dos pais a maioria tem apenas o primeiro grau incompleto (pais $38 \%$ e mães $37 \%$ ). 


\section{Procedimentos para análise dos dados}

A análise dos dados orientou-se na confluência das indicações da proposta do Discurso do Sujeito Coletivo (DSC), principalmente, de Lefévre (2002) e da análise temática de Bardin (1977). Para tanto, foram copiadas literalmente as respostas de cada entrevistado para cada questão em um quadro denominado Instrumento de Análise do Discurso 1 (IAD 1). Foram agrupadas as respostas de todos os entrevistados a cada pergunta do roteiro. Cada resposta foi analisada de forma a encontrar as figuras metodológicas propostas por Lefévre: a primeira delas é denominada expressão-chave. Chama-se de expressões-chave as transcrições literais dos discursos das respostas dadas às perguntas.

Posteriormente destacourse através do uso de elementos gráficos as idéias centrais das expressões-chave. Entende-se por idéia central a descrição do sentido do depoimento, que é dado pelo pesquisador, que revela o que foi dito pelo sujeito de forma indireta e resumida e constitui a segunda figura metodológica do método proposto.

Passou-se a agrupar as idéias centrais de mesmo sentido através do uso de letras para facilitar o reconhecimento dos diferentes grupos, que passaram a fazer parte de um quadro denominado Instrumento de Análise do Discurso 2 (IAD 2). Ao agrupá-las formulou-se uma idéia central síntese, expressando o conjunto agrupado. Essa idéia central síntese é bastante semelhante ao que Bardiin (1977 p. 105) chama de tema ou "a unidade de significação que se liberta naturalmente de um texto analisado segundo certos critérios relativos à teoria que serve de guia à leitura".

Assim, essa forma de organizar o material possibilitou a identificação das idéias previamente discutidas do ponto de vista teórico e que se encontravam contempladas pelas perguntas do roteiro. Além disso, constatou-se uma das 
vantagens da pesquisa qualitativa que prevê que no decorrer da entrevista, os sujeitos retomem e aprofundem os pontos que consideram mais relevantes. Esses aspectos foram levados em conta, ou seja, embora a organização inicial do material tenha sido feita, por pergunta do roteiro, num segundo momento, as respostas que representavam idéias presentes em outras perguntas foram reagrupadas de acordo com o sentido.

No presente trabalho optourse por não separar das idéias-centrais a terceira figura metodológica do DSC denominada ancoragem, uma vez que as crenças e valores cristalizados que constituem a ancoragem no discurso dos estudantes foram incorporados às expressões que designam os diferentes sentidos.

O DSC, a quarta e última figura metodológica do método utilizado, é formado por operações realizadas para que o discurso apresente um sentido, com começo meio e fim. Essas são realizadas pelo pesquisador nas expressões-chave para que tenham um significado conjunto. O DSC é apresentado na primeira pessoa do singular, como se o coletivo estivesse falando.

A etapa final constituiurse na criação do discurso do sujeito coletivo (DSC) para cada idéia central. Essas foram agrupadas por temas ou categorias de análise provenientes do marco teórico do estudo. 


\section{Resultados e análise}

Os resultados serão apresentados relacionando-se as idéias centrais síntese (ou temas) aos discursos dos sujeitos coletivos (DSC) correspondentes, reunidos de acordo com três categorias amplas: o que dizem os moradores do CRUSP sobre a história do CRUSP; como é morar no CRUSP; a visão dos moradores sobre o uso de drogas. As expressões-chave que geraram as idéias centrais síntese e os DSCs encontram-se no CD Rom na contra capa .

Para apoiar a compreensão dos discursos, em primeiro lugar será apresentado, em forma de quadros, o perfil dos alunos moradores do CRUSP que constituíram os sujeitos deste trabalho, levantados por ocasião da entrevista.

\subsection{Quem são os moradores que constituíram os sujeitos da pesquisa}

Os quadros a seguir, que caracterizam o conjunto dos sujeitos da pesquisa, mostram bastante semelhança com a população de estudantes moradores no CRUSP, descrita na metodologia e que serviu de base para definir os critérios para participação na pesquisa. 
Quadro 4 - Distribuição dos participantes da pesquisa, segundo a caracterização sócio-demográfica. CRUSP, São Paulo, 2003.

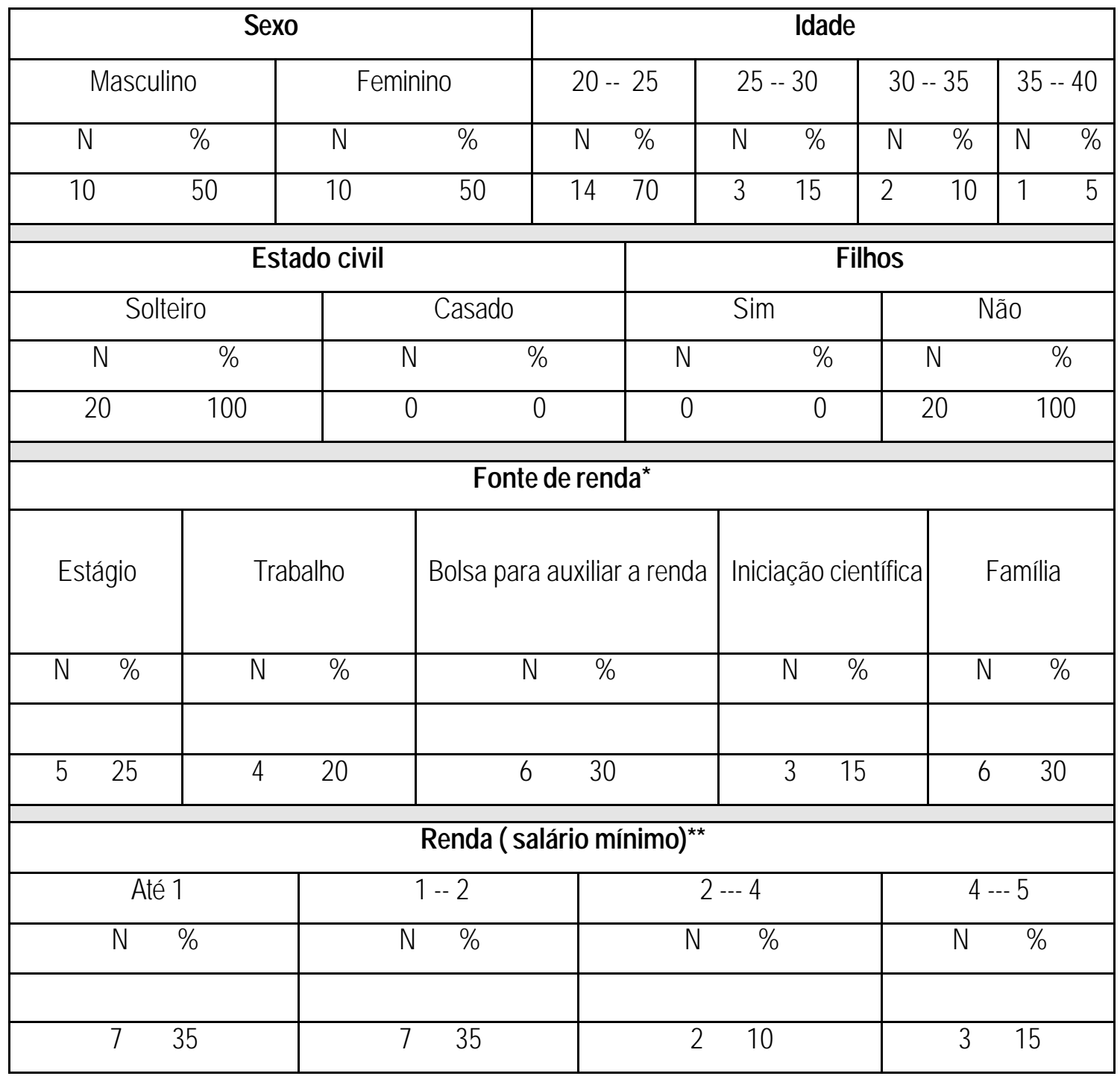

*4 entrevistados referem duas fontes de renda.

**A pergunta sobre a renda não foi feita a um dos entrevistados.

O quadro 4 demonstra que, conforme proposto inicialmente, metade dos entrevistados é do sexo masculino (10 alunos - 50\%) e metade do sexo feminino (10 alunos - 50\%). A maioria se encontra na faixa dos 20 a 25 anos de idade (14 alunos - 70\%), sendo todos solteiros e sem filhos (20 alunos $100 \%)$. Pode-se notar que a fonte de renda da maioria está na dependência do 
próprio estudante - bolsa de estudos de várias naturezas ou estágio (14 alunos - 70\%) - e está na faixa de até dois salários mínimos (14 alunos - 70\%).

Quadro 5 - Distribuição dos participantes da pesquisa, segundo o curso que freqüentam e tempo de moradia no CRUSP. CRUSP, São Paulo, 2003.

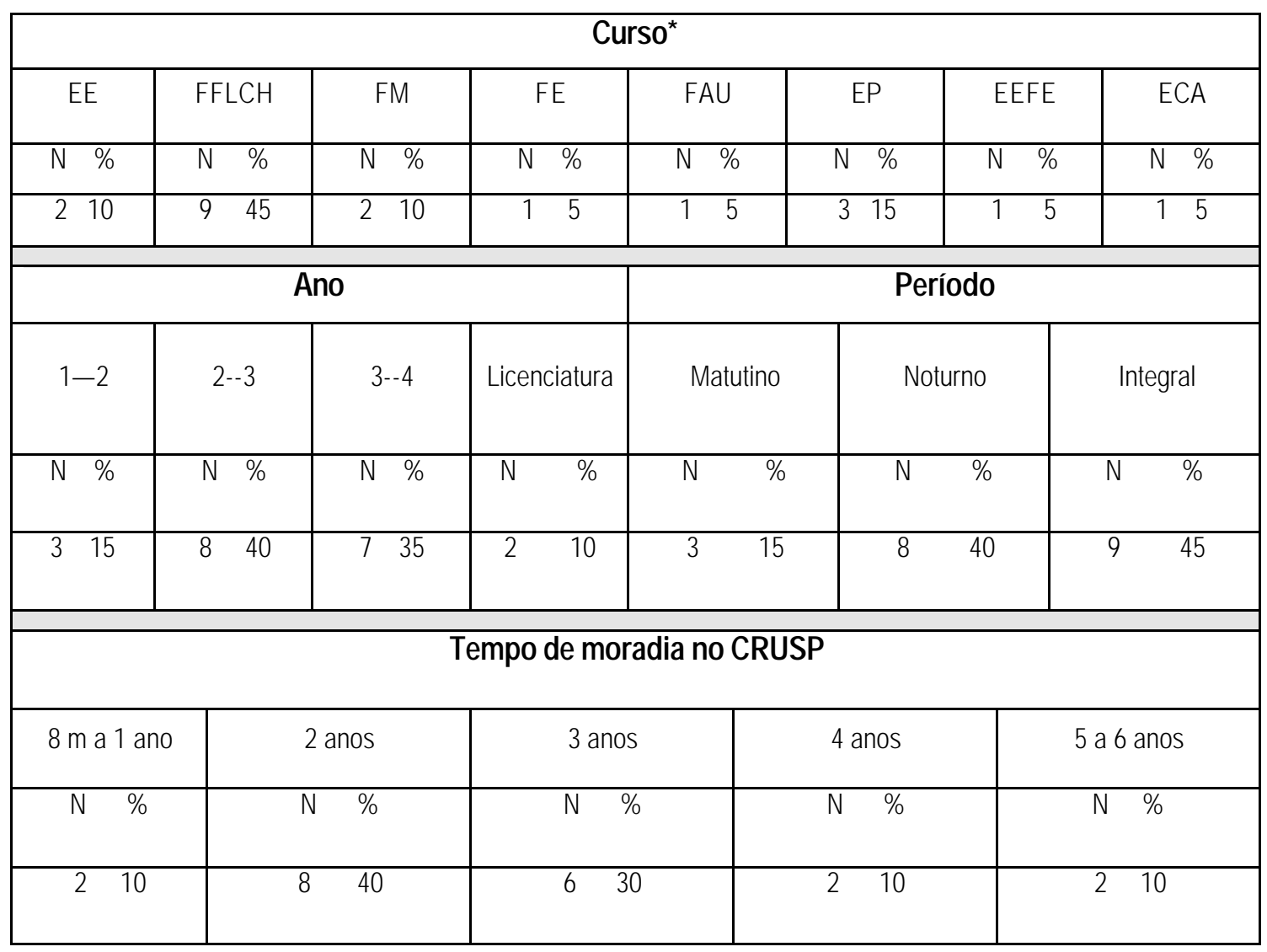

* Cursos: EE - Escola de Enfermagem, FFLCH - Faculdade de Filosofia, Letras e Ciências Humanas, FM - Faculdade de Medicina, FE - Faculdade de Educação, FAU - Faculdade de Arquitetura e Urbanismo, EP - Escola Politécnica, EEFE - Escola de Educação Física e Esporte, ECA - Escola de Comunicação e Arte.

O quadro 5 demonstra que a maioria dos entrevistados estuda na FFLCH (9 alunos - $45 \%$ ), está entre o segundo e quarto ano da faculdade (16 alunos $80 \%$ ), no período noturno ( 8 alunos $-40 \%$ ) ou integral ( 9 alunos $-45 \%$ ) e mora no CRUSP de dois a três anos (14 alunos -70\%). 


\section{Quadro 6 - Distribuição dos participantes da pesquisa, segundo a caracterização sócio-demográfica de suas famílias. CRUSP, São Paulo, 2003.}

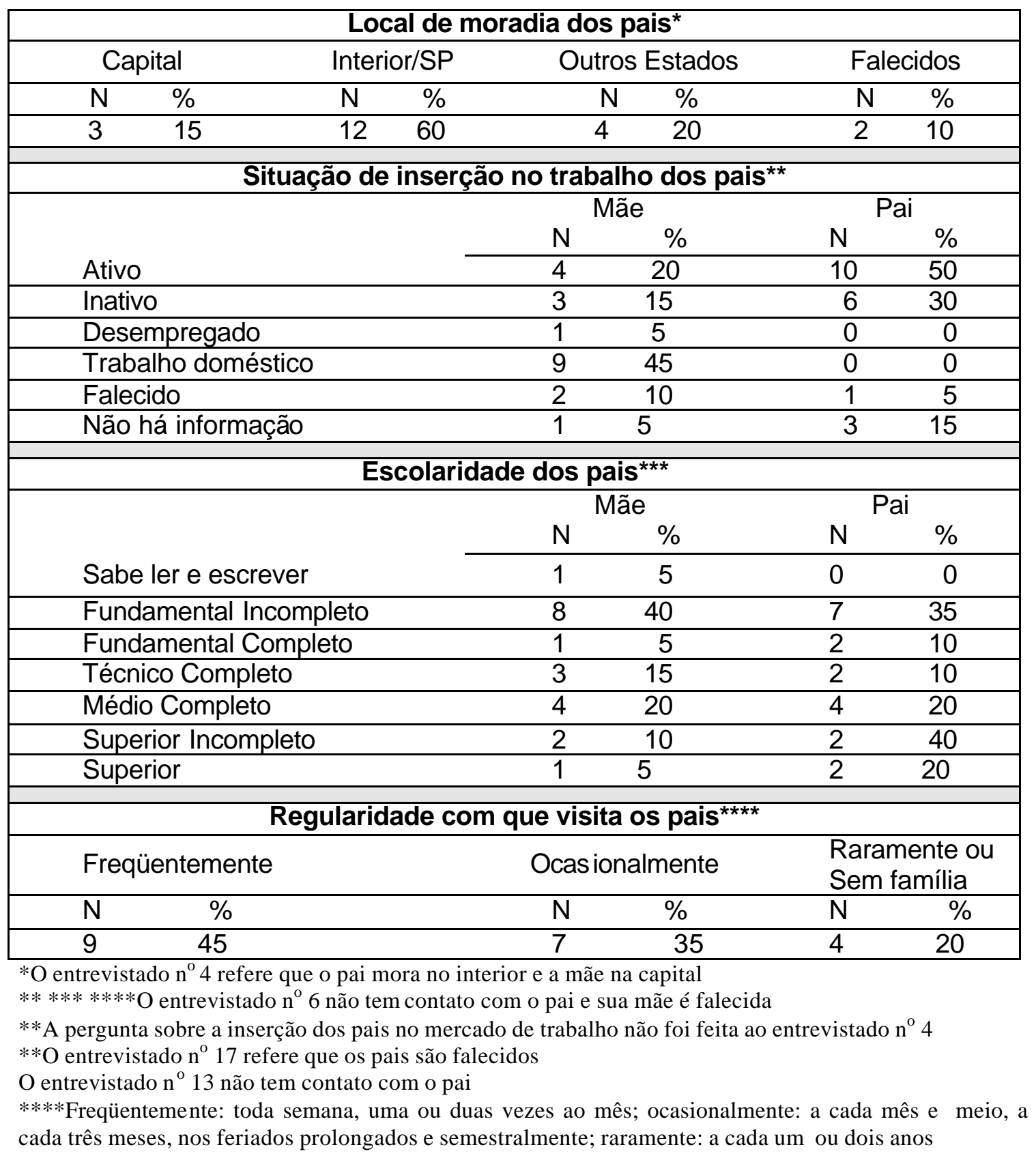

No quadro 6 verifica-se que a maioria dos pais dos alunos moradores do CRUSP mora no interior de São Paulo (12 pais - 60\%), as mães em sua maioria cuidam da casa e da família (9 mães - 45\%) e metade dos pais estão ativos economicamente (10 pais - 50\%). No que se refere a escolaridade, $35 \%$ dos 
pais não concluíram o ensino fundamental (7) e $40 \%$ das mães (8). Os filhos

visitam seus pais, em sua maioria, freqüentemente ( 9 alunos $-45 \%$ ), mas vale ressaltar a expressividade daqueles que os visitam ocasionalmente (7alunos $35 \%)$.

\subsection{O que dizem os moradores do CRUSP sobre a história do CRUSP}

Os moradores entrevistados mostram conhecer pouco a respeito da história do CRUSP, limitando-se a informações esparsas, pouco adensadas, como se pode perceber nas idéias centrais/temas e respectivos DSCs abaixo relacionados.

O discurso predominante é o de que não têm informação ou têm informação superficial no que se refere à origem do CRUSP.

\section{Não há informação ou a informação é superficial no que se refere à origem do CRUSP}

O que eu sei da história do CRUSP, não sei nada. Sinceramente não. Quando a gente veio pra cá teve uma reunião, mas eu por estudar período integral cheguei super atrasada, cheguei no final não fiquei sabendo nada do CRUSP, então não sei.

Sei que já faz muito já tempo que ele está aqui e que é só pra aluno de graduação e pós-graduação. Não sei muita coisa. Tenho uma visão superficial, de cima, não é detalhada, mais isso do que eu li nesse mural e eu escuto, eu já ouvi algumas coisas assim.

Muito pouco, da história mesmo, de como começou, mas eu ouvi falar que no começo foi um tipo de ocupação mesmo, até professores já comentaram isso. O que eu sei também é o discurso formalizado pelas entidades porque quando eu cheguei aqui eu participei dos movimentos da AMORCRUSP.

Mas se você assiste ao vídeo que o COSEAS passa quando a gente ngressa sabe um pouco disso. $\mathrm{O}$ vídeo fala muito sobre isso e tem gente que se interessa um pouco pela história do CRUSP. Eu, por exemplo, assisti aquele vídeo "Experiência cruspiana". Eu sei da fundação, de como foi 
depois que foi esvaziado no período militar, essas coisas assim, o histórico. Quando eu cheguei aqui eu tentei fazer um trabalho de campo sobre o CRUSP, a dificuldade das pessoas que vem de fora se adaptarem, então eu procurei algumas coisas.

Mas alguns recordam quase que de maneira lendária a informação de que a origem da moradia estaria ligada à possível hospedagem de atletas para jogos Panamericanos que não aconteceram devido a uma epidemia um tanto incerta também.

\section{O CRUSP foi construído para os Jogos Pan- americanos}

A gente sabe aquela velha história, que foi construído para receber os atletas que vinham aqui fazer aqueles jogos, não sei das quantas. Aqui era um alojamento e a USP ia hospedar os atletas, que eram esses blocos aqui como alojamento. Então eu sei que não foi construído pra ser moradia, era pra ser utilizado nos jogos Pan Americanos, que depois não ocorreram por causa de uma epidemia, que eu não me lembro do que. Eu acho quando tava acabando as obras teve um surto de malária, e aí se cancelou os jogos e ficou o complexo esportivo e o CRUSP. E o CEPE também foi construído meio que pra sediar os jogos que ia ser acho que no começo da década de setenta, se eu não estou enganado, e aí tiveram vários projetos e tal e ganhou esse projeto aqui.

Olha o que eu sei sobre a história do CRUSP é que originalmente parece que o projeto era pra ser a vila olímpica.

Alguns estudantes marcam a história do CRUSP sob o ponto de vista de sua estruturação enquanto moradia, assinalando a precariedade com que iniciou, algumas melhorias que foram sendo realizadas ao longo do tempo e a esperança que têm de que possa melhorar ainda mais.

\section{Houve mudança na estrutura dos prédios}

Primeiro [o CRUSP] foi construído de uma maneira bem precária e depois foi feita essa coisa de moradia, foi melhorando com o tempo, a gente sabe que teve uma época que era tudo que meio que barracão, que os prédios não foram todos acabados, tinham blocos que estavam só na parte estrutural. Nessa época, a estrutura era muito precária porque era toda de maderite, a higiene era complicada, não tinha essa divisão de três quartos era bem diferente mesmo do que é hoje em dia. 
$\mathrm{Na}$ parte de arquitetura eu sei que foi acho que do "Coron", que queria fazer um jeito de morar diferente, com as áreas coletivas, enfim essas coisas.

É foi no meio dos anos 80 e no começo dos anos 90 começou uma, uma reforma em cada bloco, começou no bloco F e veio até esse aqui que é o último bloco que foi reformado. Tanto que ele é um bloco novo, foi entregue em 2001

Eu vejo desde quando eu vim pra cá em 2000 algumas coisas melhoraram. Quando eu cheguei mesmo esse corredor hoje tem piso, era todo esburacado, era uma calçada. Isso ali eles melhoraram, eles terminaram a reforma do bloco.

Esperamos que melhore mais ainda, pelo menos o prédio tá tendo melhorias, tentando melhorar, isso quanto aos prédios.

Há de forma menos marcante, mas bastante curiosa uma certa indisposição para contar a história da constituição da moradia que vem sob a explicação de que trata-se de uma história longa ou que deve ser contada mediante algumas condições, como se a mudez significasse um protesto.

\section{Indisposição para contar a história}

A vida do CRUSP é antiga, começa nos anos sessenta, quando os prédios aqui da reitoria eram de fato moradia estudantil ainda, mas aí a história é muito longa.

Quando a reitoria devolver os nossos prédios a gente fala até dizer chega, enquanto ela não devolver a gente não vai ficar falando não.

Muitos discursos refletem conhecimento sobre a luta do movimento estudantil no CRUSP, relacionando-o a uma história conturbada, fruto de reivindicação dos alunos e até mesmo de um processo de invasão, que sofre com a presença da polícia chamada durante a ditadura militar para conter os estudantes. Os estudantes referem perseguições e mortes nesse período de conflitos e apontam o início de um estigma que marca a moradia.

O CRUSP tem uma história conturbada, com embates e lutas, de destaque no período da ditadura. É o início de um estigma.

Eu sei sobre [o CRUSP é que o] prédio onde é a reitoria era moradia, mas também sei da época do período militar, que 
teve invasão e tal, que os militares tomaram aqui e teve conflitos aqui também.

As reivindicações foram reivindicações sempre com choques entre os seguranças aqui da USP e os estudantes e essas pessoas morreram, já teve casos de mortes.

Ele [o CRUSP] foi invadido pelos estudantes depois várias vezes e foi interditado pela polícia. Várias coisas ocorreram, principalmente no regime militar muita gente foi presa e [esse espaço] ficou durante muito tempo fechado.

Depois os alunos voltaram a invadir e nessa época ele era usado pela universidade um dos blocos era o MAE, Museu de Arqueologia e Etnologia, eles invadiram e ainda estavam lá as peças do museu e foi muito complicado.

Mas, quando houve a ditadura, o golpe de 64, muitos estudantes invadiram e o CRUSP passou a ser conhecido como reduto da clandestinidade, de pessoas que contestavam a ditadura e que eram intensamente perseguidas.

Eu acho que esse foi o início da má imagem que o CRUSP tem hoje na sociedade. Então é um histórico assim bastante conturbado realmente.

\section{A moradia foi uma reivindicação dos alunos}

[O CRUSP] surgiu a partir da reivindicação dos alunos a algumas décadas, duas ou três décadas. Com o passar do tempo, os estudantes começaram a reivindicar a ocupação desses apartamentos. Assim, o CRUSP foi uma reivindicação dos alunos, como um direito. Eles começaram a usufruir do espaço.

O que eu sei é mais ou menos isso, e que dali saíram muitas pessoas que lutavam pela universidade.

\section{Para morar no CRUSP os alunos tiveram que invadi-lo}

Olha, eu sei que a moradia foi conseguida a custa de um pouco de luta, que as pessoas acabaram invadindo esses prédios, parece que foi uma luta dos alunos, uma requisição. Os prédios estavam ociosos, aos poucos foram sendo ocupados por estudantes que não tinham condições de pagar, sendo regulamentado aos poucos.

Poucos alunos relacionam a história do CRUSP à da COSEAS, que surgiu para regulamentar a moradia. 
No passado não havia controle sobre quem morava no CRUSP, a COSEAS foi criada para regulamentar isso

Aí chegou uma época que morava gente que nem era da USP, não havia o controle. Depois foi criado o COSEAS pra regulamentar isso. Que tinha pessoas que não eram da USP e que moravam aqui e que mais que eu posso falar assim era uma zona aqui, tinha morte, tinha tráfico de drogas e tudo e o COSEAS foi criado pra acabar com isso e regularizar um pouco isso e junto também foi criado a associação de moradores do CRUSP.

Também apareceu a idéia de que o CRUSP sempre foi uma moradia destinada aos alunos pobres e que moram longe da universidade.

\section{Os critérios para entrar no CRUSP sempre foram a distância da casa e situação sócio-econômica}

Eu tenho conhecimento que [o aluno] foi sempre avaliado pela situação sócio-econômica [para entrar no CRUSP], todos os moradores. E que quanto mais longe você mora, mais fácil de você conseguir, eles dão prioridade para pessoas que moram mais longe.

\subsection{Como é morar no Crusp}

Nesta categoria estão reunidas todas as idéias centrais síntese e os Discursos do Sujeito Coletivo correspondentes que se referem aos benefícios, dificuldades e formas de enfrentar as dificuldades e preconceitos vividos pelos moradores do CRUSP.

Em primeiro lugar, o que se percebe é que os moradores explicitam o fato de que morar no CRUSP viabiliza estar na universidade porque eles não têm gastos com moradia, podendo inclusive comprar alguns livros; há melhora na qualidade de vida na medida em que não se gasta tempo com trânsito, podendo se dedicar mais aos estudos e usufruir do ambiente do campus e de recursos como o CINUSP, por exemplo; por fim, alguns poucos apontam para a 
tranqüilidade do ambiente, admitindo inclusive que pode ser bom ficar aos domingos no CRUSP; e mesmo o alojamento pode ser positivo se o estudante está interessado em ter alguma cultura geral.

\section{Morar no CRUSP é bom porque não se tem gastos com a moradia e isso viabiliza estar na Universidade}

Positivo eu acho que é claro, não paga nada, não paga luz, não paga água, não paga aluguel, simplesmente mora lá. Isso é uma coisa que pra quem realmente precisa eu acho que ajuda demais. Eu não teria condição de pagar uma moradia tão perto da Universidade, muita gente que mora aqui sem essa moradia ia tornar impraticável a faculdade.

Aqui você consegue administrar muito bem o dinheiro porque além da moradia você tem uma sustentação que é a bolsa alimentação, a bolsa trabalho. Então você realmente é sustentado por um aparelho que é uma rede de relações que te sustenta aqui que dá condições pra você, mesmo que você ganhe pouco com a bolsa você tem condições de mobilidade maior. Uma coisa que muda [ao] morar no CRUSP também é o seu padrão de consumo, acho que seria muito diferente se eu morasse na minha cidade e estudasse aqui, por exemplo, eu pensaria duas vezes em chegar numa livraria e gastar trinta reais num livro e eu fui entrar [pela primeira vez] no cinema aqui no CINUSP.

Um outro ponto é que o meu curso antes do CRUSP e depois do CRUSP não tem nem comparação, também pela pesquisa, experiência de pesquisa que eu tive dois anos de bolsa na Pedagogia, isso me ajudou muito assim. Então tinha aquela fonte de renda, você tava aqui, bolsa moradia, bolsa alimentação, entendeu? Eu não tinha praticamente preocupação nenhuma foi um período maravilhoso pra mim enquanto durou a pesquisa.

Também acho que a gente mora num lugar é privilegiado assim que é bastante arborizado, bem tranqüilo, tem os pássaros, assim, pra São Paulo é um lugar legal pra se morar.

\section{Morar no CRUSP melhora a qualidade de vida dos alunos}

De positivo a facilidade, você não perde tempo no trânsito, você tem acesso a todas as coisas aqui dentro muito fácil. Não tem estress pra chegar na faculdade, está perto das bibliotecas e dos laboratórios, você consegue viver um pouco mais intensamente a vida acadêmica claro, isso se você se 
dispuser a tal. Você acaba ficando mais tempo aqui [na Universidade] e aproveitando seu tempo aqui. Então tipo você às vezes pode assistir uma matéria a tarde que você não poderia se você tivesse que ficar se locomovendo.

A faculdade fica aqui do lado, tem várias atividades aqui dentro, você conhece bastante gente de lugar diferente, você vivencia a universidade de outra forma porque você não vai pra faculdade você está dentro da faculdade.

É um lugar tranqüilo, eu nunca vi acontecer nada de mais assim, tem uma discussão ou outra.

Morar e estudar no mesmo lugar é uma vantagem, o verde é outra é uma área muito gostosa aqui.

Quem mora no CRUSP, trabalha na USP e estuda na USP respira o campus $24 \mathrm{~h}$ por dia. Então isso eu acho uma vantagem bacana, você acaba tendo uma qualidade de vida boa nesse sentido, principalmente pra quem estuda a noite, que geralmente trabalha então é mais corrido.

\section{É bom morar no CRUSP}

Eu acho o lugar agradável, eu me sinto em casa como se eu estivesse na minha própria casa, aonde eu moro ali o bloco é muito tranqüilo. No geral eu acho bem legal, acho que é difícil ter a oportunidade de estar em lugares assim, ter uma universidade que ofereça moradia, eu acho até legal.

\section{É bom ficar no CRUSP no domingo}

A gente fica [no CRUSP] numa boa, um domingo é gostoso passar aqui pra descansar, legal pegar a bicicleta sair, passear, comprar alguma coisa no mercado e voltar, tranqüilo.

\section{É positivo morar no alojamento para quem está descobrindo a cultura}

Quando eu cheguei eu fiquei seis, sete meses num alojamento que chegou a ter 50 pessoas morando no quarto. Era muito legal porque de repente a mina chegou pra mim a gente conversando sobre literatura chegou falou assim é o seguinte vou fazer uma lista pra você de filme você vai lá você assiste porque ninguém pode passar sem assistir esses filmes.

Dentre os aspectos positivos identificados pelos alunos tem-se também: para alguns a infra-estrutura oferecida é suficiente para quem quer estudar

(mas só para quem deseja estudar, porque morar no CRUSP não se constitui 
em possibilidade de ascensão como tornar-se professor da USP por exemplo);

para outros há ênfase na possibilidade de aprender a conviver com a diversidade e aprender com pessoas de outras áreas e até mesmo o cuidado dispensado pelos funcionários do CRUSP (faxineiras e porteiros) aos alunos da moradia é observado por alguns estudantes.

\section{O CRUSP oferece a infra-estrutura necessária para quem quer estudar}

Bom, pra mim eu acho que pra estudar, pra quem tem o propósito de estudar, como é o meu caso, eu acho um espaço extremamente agradável, porque você tem a sua privacidade, você tem o seu quarto, uma escrivaninha a cama o guardaroupa tudo que você precisa pra estar aqui estudando mesmo. Você pode estudar tranqüilamente é silencioso é bem arejado, claro, acho bem legal, pelo menos no bloco onde eu estou dá pra estudar sem ser incomodado com o som alto.

Pra mim que só moro e fico aqui de dia de semana pra estudar eu acho que são quatro anos a gente passa numa boa. Então se você vem de muito fora de uma outra realidade que não é a universidade é bastante positivo porque você observa e aprende, agora se isso aqui for seu objeto de consumo, se você de fato quiser virar professor aí é lamentável.

\section{Morar no CRUSP ensina a conviver com a diversidade}

Ali no meu andar todas as pessoas conversam se dão bem, respeitam, o silêncio, eu não posso reclamar de nada pelo menos no meu bloco, a convivência ali onde eu moro é muito boa. Então acho que isso que tem isso de positivo, assim a gente troca, ali nos meus vizinhos, eles são de outros cursos, a gente está sempre junto conversando acho isso legal. Assim como tem pessoas de outros países ali no meu andar, acho que isso tem de positivo, as diferenças, mesmo, você vê gente com culturas completamente diferentes da sua e que de repente você nunca tinha visto uma determinada coisa, mas a partir do momento que você vê, você começa a aceitar melhor o outro e as suas diferenças.

O CRUSP é uma espécie de redemoinho cultural é muito bom para quem vem das classes mais baixas. Tipo onde gente de tudo que é lugar, com diferentes experiências chega com a vontade de querer trocar na verdade com a necessidade de ter um diálogo e tal e isso foi muito bom pra mim porque até então, por exemplo, eu fui conhecer a primeira pessoa que 
fazia sociais aqui na faculdade. Então na verdade você sente essa necessidade de trocar e tal aí quando você chega você fala nossa! Que mundo é bem legal! Acho que pra mim foi positivo não só pelo lado econômico, mas pelo lado de experiência mesmo.

\section{Os porteiros e faxineiras "cuidam" dos alunos}

E sei lá, eu acho que existe uma atenção muito boa por parte dos porteiros, eles anotam os recados, os telefones, alguns sabem até o seu nome, se metem na sua vida, sua mãe ligou duas vezes e você não estava. Isso eu acho até legal porque, a gente ta aqui sozinho. Tipo, ninguém vê a hora que você chega ora que você sai, acontece alguma coisa com você ninguém dá falta. Então eu acho legal essa preocupação. Eu gosto dos porteiros aqui do meu bloco, acho els muito atenciosos, a moça que limpa o corredor também.

Alguns alunos referem que participam de atividades extra-curriculares no Centro de Práticas Esportivas da USP ou na própria faculdade, mas quase não participam de atividades oferecidas particularmente aos moradores do CRUSP, realizando-se a sociabilidade principalmente nas festas com os amigos. Há quem encontre dificuldades para levar adiante os projetos nessa área liderados pela COSEAS.

\section{Participa de atividades extra-curriculares na faculdade e no CEPEUSP}

O que eu participo mesmo é [de atividades] mais ligadas à faculdade [ou] alguma coisa no CEPEUSP. [As atividades] ficaram bastante restritas à faculdade depois de um certo tempo. Você acaba encaixando suas atividades acadêmicas com as atividades de lazer com esse [mesmo] grupo, aí é mais fácil concatenar

\section{Participa de festas com amigos}

Geralmente a gente faz algumas festas [ou] vai na festa de alguém. Quando surge a gente ah! meu vamos dar uma desencanada, vamos fazer uma festa na casa de fulano, na casa de cicrano.

É uma coisa que vai mais de acordo com todo mundo, tipo, tem sempre aquela mesma galerinha, que sabe mais ou menos o quê vai fazer, então é uma coisa que prende também, 
uma coisa que eu percebo aqui é aquela questão dos grupos, você circula em algumas festas tal, mas tem uns grupos que tem mais a ver com você, sua afinidade, seu estilo de vida, seu tipo de vida.

[No meu caso eu só vou] nas minhas festas[ou dos] meus amigos do bloco $\mathrm{F}$, ali [naquele] apartamento. [Se] eu organizar a entrada é restrita, não é pública, de jeito nenhum. Eu abomino esse caráter público das coisas, então as coisas que eu faço são privadas, privativas. Não, é que o pessoal é cheio de querer entrar na festa, acha que tem direito.

\section{Participa de atividades extra-curriculares como coordenador}

Eu sou coordenador de um coletivo militante aqui na universidade que é o coletivo movimento popular. O coletivo movimento popular é um coletivo afro brasileiro, que defende a inserção dos negros na universidade, mas de uma forma bastante criteriosa, então a gente defende as cotas, as ações afirmativas na USP, mas sempre acompanhada da assistência estudantil, não porque a gente quer disputar poder não, porque se nós formos disputar poder com a reitoria ou com a universidade, a gente tem que lembrar que isso aqui é um espaço do Estado e disputar poder com o Estado é reconhecer que o Estado é alguém mais forte e eu acho que os negros não precisam disso.

Eu tenho essa bolsa do CRUSP que é da COSEAS que chama qualidade de vida no CRUSP e a minha função é organizar eventos esportivos, eventos assim de lazer pra moradores do CRUSP. Eu encontro uma certa dificuldade pra colocar isso em prática porque é preciso sempre de alguma verba pra comprar alguma coisa e tal e eles estão em contenção de gasto, então acaba demorando pra conseguir organizar alguma coisa.

\section{Participa de atividades extra-curriculares oferecidas para os moradores}

Eu entrei agora no coral do CRUSP, eu jogo bola aqui em baixo com o pessoal que mora no CRUSP, fora isso assisto vídeo [no] CRUSP, fui só uma vez também, quer dizer duas vezes nesses anos todos e só.

Do lado das dificuldades os alunos apresentam motivos para não participarem de atividades extra-curriculares: falta de tempo devido às exigências acadêmicas ou à necessidade de trabalhar (se trabalhar fora do 
campus terá menos oportunidade de aproveitar o que a universidade oferece), desorganização no planejamento e divulgação das atividades e mesmo a própria desorganização.

\section{Não participa de atividades extra-curriculares por falta de tempo devido às atividades acadêmicas}

Eu não participo de nada, eu não tenho muito tempo por causa da faculdade. $\mathrm{O}$ meu tempo é bem corrido, então às vezes eu não consigo nem dar conta das coisas que eu tenho que fazer mesmo de faculdade. Não participo primeiro que o seguinte, é engraçado parece que quanto mais tempo você tem mais coisa você tem pra fazer. Antes eu estava mais interada das atividades da Associação de moradores, agora eu já não estou tendo muito tempo.

Eu não sei, na verdade a gente participava bastante nos primeiros anos aí depois você vai acumulando uma série de coisas e compromissos e tal.

\section{Não participa de atividades extra-curriculares no CRUSP, pois tem que trabalhar}

Quando eu entrei, ingressei no CRUSP eu pensei seriamente em me envolver com o pessoal da AMORCRUSP até constituir chapa pra disputar eleições, mas o fato de eu depender, ser a única pessoa que me mantém, única pessoa responsável por me manter [me impediu]. A preocupação principal que passou a tomar conta de todo o meu tempo foi à necessidade de conseguir um emprego, um estágio pra possibilitar a minha estada aqui no CRUSP [pois] o curso é gratuito mais na realidade tem um custo com xerox e tudo mais. E isso dificulta sobremaneira esse envolvimento mais político e com os próprios moradores também, mas eu no início tinha esse desejo muito forte. Com o passar do tempo a necessidade de se manter me obrigou a priorizar outras coisas. Atualmente eu não tenho nenhuma atividade ligada diretamente aos moradores.

[Além disso], as reuniões da AMORCRUSP são todas a noite, às 8 então logo que eu comecei a trabalhar eu não pude mais ir. Como eu preciso trabalhar então eu não crio vínculo com essas atividades porque eu não vou ter tempo de estar participando.

Como durante o meu curso eu tive de trabalhar o dia todo e estudar a noite e muitas das atividades oferecidas no CRUSP são durante o dia ou mesmo após o período de aulas noturno, então algumas atividades dez e meia, onze horas 
como o coral que começou a ensaiar no ano passado eu acho, eu me sentia sobrecarregado e não tinha aquele pique pra participar.

Existe também um outro programa que chama vídeo CRUSP onde são oferecidas sessões de filmes atuais até todos os fins de semana, isso eu nunca participei ou por falta de interesse ou por não estar no campus no fim de semana, não estar no CRUSP no fim de semana

Quem trabalha em período integral fora do campus não pode aproveitar o que o campus oferece

Tem pessoas que trabalham o dia inteiro fora do campus, então não conseguem aproveitar plenamente o que a universidade oferece

\section{Não participa de atividades extra-curriculares, por desorganização no planejamento e divulgação das atividades}

Eu já tentei fazer alguma coisa, alguma atividade física, pensei em fazer natação m CEPE, mas nunca condiziam os horários, aí sozinha também eu não vou.

[Além disso], eu não tive oportunidade, não tem ninguém que eu conheça que tenha me chamado, também eu não me interessei. Eu sempre tinha vontade de ir assim, mas nunca fui, eu queria ir num negócio que tem aqui de atendimento psicológico, coral eu queria ver como que é, as assembléias do AMORCRUSP também teria que ir, eu nunca vou assim eu vou adiando, adiando.

[Tem o fato de que] eu já tentei participar de outras coisas que acabaram não saindo do papel. Uma vez tentaram, já há algum tempo tentaram alguma coisa de conscientização de reciclagem do lixo, coleta seletiva, mas ficou muito no papel e acabou não indo pra frente.

[As atividades] não são muito bem divulgadas, você só vai ficar sabendo pelos murais se você não ler, você não fica sabendo

Agora em festa eu nunca fui, eu não gosto. Mas também aqui não tem muita festa pelo menos de dia de semana não tem não pode ter de final de semana também eu não vejo muito assim, eu não fico sabendo também de muita festa 


\section{Não consegue se organizar para fazer uma atividade física}

Eu sei que assim todo começo de ano, início de semestre eu falo não agora eu faço tal coisa, agora eu vou fazer, por exemplo CEPE, fazer algum esporte. [Eu] sempre me inscrevo, mas nunca dá, então já estou no fim [do curso] e até hoje não consegui fazer nada, que horror !.

Alguns alunos, independente de participar ou não, listam as atividades oferecidas especificamente aos moradores do CRUSP, mostrando estar informados sobre elas.

\section{Conhece as atividades extra-curriculares oferecidas aos moradores do CRUSP}

[Aqui no CRUSP] tem grupo de teatro, coral, dança, tem os filmes que passam no bloco $\mathrm{B}$, que eu só fui umas vezes.

O quê que tem de lazer oferecido pelo COSEAS é o filme no fim de semana, eu não assisto, a pró-aluno eu não gosto de usar, que é muito cheia a noite, tem [também] o ateliê do Moisés Voador ali, que é um lugar de confraternização de grupos o qual eu não me enquadro neles. Eu não participo de evento nenhum aqui no CRUSP.[Não participo das] atividades programadas, organizadas pela COSEAS pros estudantes.

[Mas] volta e meia eles avisam [sobre] novas atividades, como por exemplo, atividades culturais como capoeira, que eu já vi, cheguei até a assistir. Estão constituindo agora o cursinho do CRUSP, eu acho uma iniciativa interessante, curso de inglês também pra comunidade mais barato, tem também esse tipo de atividade, com certeza devem ter outras mas eu não tenho envolvimento muito forte não, conheço alguns responsáveis pelo AMORCRUSP, mas não tenho envolvimento forte, não, um vínculo forte não

No que se refere às expectativas sobre a convivência no CRUSP, podese encontrar tanto aqueles que se surpreenderam positivamente como aqueles que tinham uma expectativa inicial alta e que se decepcionaram. A superação das expectativas fica por conta de encontrar pessoas que, ao contrário do estigma veiculado, são "normais", conversam, arrumam a casa, fazem comida, vivem a vida.... A decepção com a convivência fica por conta do individualismo dos estudantes, que não têm espírito coletivo, mesmo sendo na sua maioria da área de humanas. 


\title{
Morar no CRUSP surpreende, supera as expectativas do estigma atribuído aos moradores
}

Eu fiquei surpresa, assim positivamente, eu não reclamo de morar aqui, eu acho que eu não tenho do que reclamar. Olha, eu de verdade nunca tive problemas. Antes de entrar aqui a gente tem medo, porque quando a gente comenta que está concorrendo a vaga tal as pessoas já olham com uma cara feia, tipo você vai ter coragem de ir morar lá? [Isso me] incomodou no começo porque eu tinha essa idéia do CRUSP, mas depois que eu comecei a morar aqui que eu vi que não era nada daquilo não me incomodou mais. É muito mito, tem muita lenda em torno de bagunça, dizem que rolam altas orgias, não orgia, mas que é tudo muito bagunçado, mas depois que eu vim pra cá, eu vim meio assim, sem saber mesmo o quê que eu ia encontrar, mas eu acabei dando não sei se foi sorte, mas nunca tive nenhum problema de verdade.

Quando eu entrei aqui as pessoas que moravam também eram organizadas, eu entrei era tudo arrumadinho, bonitinho, as pessoas conversavam. No final de semana a gente fazia almoço junto, a noite pedia pizza, a casa era arrumadinha, a gente tinha compromisso de cada um limpar uma semana e tudo.

\section{Há uma decepção a partir da convivência no CRUSP}

Eu me decepcionei de morar aqui, antes eu tinha uma certa segurança porque a grande maioria dos alunos que moram aqui faz ciências humanas. Então eu pensei assim são pessoas razoáveis, pessoas que lutam pelo espírito coletivo, pessoas que sabem lidar em grupo e quando eu cheguei aqui e não era nada disso, me decepcionei muito vindo morar aqui. Depois eu fui me decepcionando assim com as coisas, com convivência, com uma forma um pouco egoísta de ver as coisas e tal.

\begin{abstract}
Ainda do lado das dificuldades os alunos apontam, de maneira expressiva e ao contrário de alguns poucos que não veêm problemas na moradia, que para que se possa morar no CRUSP é preciso minimizar problemas, como a solidão, para tanto é preciso sair do CRUSP nos finais de semana. Caso não saiam podem acabar isolando-se também do convívio social mais amplo. Isso se deve, entre outros fatores, ao distanciado campus da USP, onde se localiza o CRUSP. Como conseqüência, os alunos correm o risco de
\end{abstract}


passar a viver num mundo à parte o que pode gerar uma desconexão com a realidade. Há também a possibilidade do aluno se envolver em outras atividades e deixar o curso em segundo plano. $O$ isolamento do campus e a falta de infra-estrutura geram também problemas relacionados à alimentação e ao acesso a outros bens de consumo nos finais de semana.

Claramente, os alunos apontam que os padrões de sociabilidade dos jovens são alterados em função do isolamento a que ficam submetidos nos finais de semana, uma vez que, como foi visto, poucos conseguem ir para casa, sendo a solidão então apontada como conseqüência desse isolamento. Nesse contexto sintomas depressivos podem aparecer, agravados pela falta de apoio para trocar idéias seja com familiares, seja com amigos.

\section{É preciso sair do CRUSP nos finais de semana caso contrário pode-se ficar isolado do mundo, solitário}

O lado ruim que eu vejo é um pouco do isolamento, porque na verdade assim isso aqui é uma parte totalmente separada da cidade parece que o mundo é ali depois do rio Pinheiros, aqui é um outro lugar.

Tem isso, no final de semana você está cansado, aí você fica aqui. Tipo, eu estudo aqui, moro aqui e trabalho aqui, se eu não me animar no final de semana a sair, você fica isolado do mundo porque aqui é um mundinho a parte. Acho que isso prejudica um pouco e prejudica um pouco também o isolamento porque as pessoas aqui elas não se comunicam muito.

Nos finais de semana o tempo é muito ocioso no CRUSP, as pessoas tem pouca atividade pra fazer lá dentro, então assim os problemas se intensificam. Você está sozinho longe da família, se de repente você não tem um amigo ali, tem sempre um dia que você tá mal, que você está chateado e você não tem ninguém pra se apoiar, então eu acho que a ociosidade no CRUSP de finais de semana principalmente é um ponto crucial.

Outra desvantagem é a distância dos outros lugares, o afastamento de tudo e tem também o fato de que no final de semana a gente fica meio que ilhado aqui porque os ônibus não podem entrar, por um lado eu entendo por questões de segurança, mas não sei até que ponto efetivamente isso assegura uma segurança maior.

Você tem que estudar ou ir pra sua casa no final de semana. Se você sair com frequiência dá pra conciliar, mas 
ficar o tempo todo aqui nesse clima, o tempo passa e como já bateu em mim, dá uma certa angústia Tem que sair pra poder passear, se você não sair não é muito legal, não dá pra ficar aqui o final de semana inteiro, assim, dá pra ficar, mas você sempre vai querer passar do portão prapoder dizer, puxa eu saí.

Outra coisa que facilita um pouco é esse negócio de estar sempre próximo da família, mas já é uma coisa mais difícil quando você não tem a família aqui, aí bate aquele esquema, aqueles problemas, solidão.

Tem também o pessoal que se aliena usando muita droga aqui na faculdade, estuda a semana inteira no final de semana vai beber e se drogar aqui, você fica aqui alienado, porque aqui a gente fica isolado.

Há assim um lamento de que a situação de ficar o tempo todo no CRUSP aliena da realidade social de outros espaços, o tempo sendo todo tomado para estudar e cuidar das tarefas cotidianas.

\section{Morar no CRUSP gera desconexão com a realidade}

Eu acho que é muito estranho a gente acaba ficando isolado, você acaba começando a viver num mundo a prrte porque são regras diferentes, são costumes diferentes e a gente brinca que a gente está na bolha, na ilha, num jardim zoológico mesmo, porque é tudo tão organizado e você sai pensando que a sociedade é isso mesmo. É um lugar onde você pode ficar mais a vontade é um lugar vigiado, é uma espécie de um condomínio fechado aqui. Tem menos vantagens do que aqueles condomínios fechados no sentido clássico, mas essa coisa, esse desprendimento da realidade social, é o fato de você de repente quando você sai demora um certo tempo pra perceber que desemprego existe e que a pessoa não tem dinheiro pra comprar tal coisa.

Mas também devido a correria dos estudos, trabalho e tudo mais eu que não vou pra casa então eu tenho que cuidar da minha roupa, não tenho a facilidade de levar pra casa e lavar e da comida. Então o fim de semana seu acaba sendo muito corrido, muitas vezes você acaba ficando muito aqui dentro, eu trabalho aqui dentro, estudo aqui e moro aqui, então você meio que perde a ligação direta com o mundo lá fora, sabe?

Nesse processo, os alunos podem se perder.... 


\section{Um dos problemas do CRUSP é que alguns alunos deixam a faculdade em segundo plano}

Um dos problemas principais que eu vejo é que a gente está morando aqui por causa da faculdade, só que muita gente perde essa ligação e acaba deixando a faculdade pra segundo plano. Segundo, terceiro, quarto plano então acaba ficando muito aqui e esquece das obrigações de ir pra faculdade e tal, eu acho isso muito difícil. As pessoas tinham que pensar de uma forma diferente, primeiro a faculdade eu estou morando aqui em conseqüência da faculdade e acaba sendo o oposto, a faculdade que está no seu quintal praticamente. E muito complicado, essa relação é muito complicada.

Com muita ênfase apontam como agravante do isolamento problemas de infra-estrutura como a impossibilidade de acessar alimentação, uma vez que o restaurante central é fechado, o transporte é insuficiente e distante, a farmácia é fechada entre outros problemas.

\section{Dificuldade de acessar alimentação e outras necessidades de consumo no final de semana}

É isolado de tudo, no final de semana aqui principalmente é complicadíssimo você permanecer aqui no CRUSP, que é tudo fechado pra você fazer compras. Tem uma série de impedimentos que dificulta a vida normal, a você viver satisfatoriamente aqui.

Você tem que resolver problemas do tipo o quê comer e por incrível que pareça, o restaurante central é fechado, quer dizer que só tem moradores, pro pessoal da USP, de segunda a sábado, no sábado até o almoço. Isso dă a entender que o pessoal morador do CRUSP não janta no sábado e nem almoçam e jantam no domingo, porque tá tudo fechado então tem que sair.

Agora até que melhorou um pouco que eles abriram a conveniência ali, uma padaria, um mercadinho tem várias coisas, então ajuda, mas antes não tinha nada absolutamente nada. Mas só tem essa conveniência e assim é um preço médio não é nem barato nem caro, eles não tem uma concorrência de outros lugares e só tem lanche não tem refeição.

Em relação a farmácia às vezes você fica doente precisa de remédio também a daqui fica fechada aí é um saco.

Além disso, não tem mais ônibus, então você tem que andar até a portaria um pra pegar um ônibus pra comprar alguma coisa. 
Os próprios alunos apontam alternativas para enfrentar o problema da solidão e do isolamento no CRUSP: transformação do apartamento em um espaço de convivência e organização de atividades de lazer diversificadas que possam se constituir numa oportunidade de socialização. Além disso, referem ser de suma importância sair do campus nos finais de semana e compreender a transitoriedade da condição de morador, não depositando na moradia o peso de uma situação estável quando se faz projetos de vida.

\section{É necessário construir uma convivência no apartamento se a meta não for viver isoladamente}

Tipo, aqui nesse apartamento a condição de quando eu entrei e quando a $\mathrm{M}$ entrou depois que eu, foi que a gente não quer saber de quarto com porta fechada, pessoas que ficam o dia inteiro em quarto, porque é um espaço onde você tem que conviver, não é? Senão ficam três apartamentos separados, porque cada um fica no seu quarto, isso é importante.

A gente tenta pelo menos transformar o nosso apartamento como se fosse a casa da gente, então o que a gente gosta de ter, como a gente gosta de organizar a casa da gente, a gente procura fazer no nosso apartamento. Então a gente se sente super bem, porque é como a casa da gente, se a gente não gostar da onde a gente vive você vai pra casa e vai fazer o que, entendeu? Só tem lá pra ficar. Então acho que é procurar ver o lado bom mesmo.

\section{É preciso ter atividades de lazer diversificadas}

Para o pessoal que fica aqui direto, eu não sei, eu acho que é ruim porque tem que fazer disso a sua casa, tem que dividir esse espaço com sala com, pra receber alguém, pra ter um pouco de lazer porque lazer aqui é difícil tem o CEPE, mas é só esporte. Eu acho que devia ter mais lazer, mais festas às vezes, o cinema também é legal, às vezes passa coisa que o pessoal não gosta muito, mas também são poucos horários, então de lazer fica meio solitário também.

As atividades podem ser uma oportunidade de socialização

Eu acho interessante [a realização de atividades pois] é uma opção de lazer e uma oportunidade de pessoas estarem em contato. 


\section{É preciso sair do CRUSP no final de semana}

Eu não gosto de ficar aqui no final de semana, ás vezes eu vou no CEPE no sábado, tudo, ou vou andar de bicicleta se for o caso, mas eu prefiro sair, porque eu já fico aqui a semana inteira, eu acho importante sair.

Não é legal ficar aqui [no CRUSP] o tempo todo. Você passou a semana inteira num lugar só, então você quer sair, mas isso daí acontecia até [quando eu morava] em casa. Acho que não muda muito nesse sentido. Eu acho que pode ser entediante dependendo com quem você mora, não é o CRUSP. O ruim de ficar aqui é que não é legal ficar parado, se você mora aqui você não quer ficar, se você morar na sua casa, você está a semana inteira na sua casa você quer sair um dia pra poder passear é a mesma coisa praticamente.

\section{O CRUSP deve ser visto como espaço provisório de moradia}

Eu tenho com quem morar, tipo, o $\mathrm{G}$ é meu namorado e mora aqui só que [ele] não era meu namorado virou um ano depois que eu morava aqui. Aí eu acho que a gente tem que aprender a separar as coisas porque realmente você tem que ver que isso aqui é um espaço provisório, que é pra você estudar, ter a sua vida durante quatro, cinco anos que for o teu curso aqui e não de repente começar a construir uma vida aqui. Eu sei que tem gente que mora sete, oito anos [e tem] filho. [Eu] acho que é prejudicial até pra essas pessoas, mesmo, porque você não consegue se estabelecer na vida direito você se encosta mesmo.

Há outras dificuldades de sociabilidade: o ambiente não propicia uma aproximação entre os moradores e o barulho feito por alguns moradores que não respeitam o silêncio à noite incomoda outros moradores; pode parecer à

primeira vista, segundo alguns alunos, um ambiente alegre, mas é perturbador. Os alunos referem ainda que muitos dos seus colegas não têm noção sobre viver em coletividade, não valorizam a moradia e isso se reflete por exemplo, na sujeira deixada nos corredores depois de uma festa. Um outro aspecto levantado sobre a sociabilidade é a precariedade do alojamento, onde se vive com muitas pessoas no mesmo quarto sem nenhuma privacidade.

Assim, as formas de sociabilidade da metrópole urbana contemporânea se refletem no comportamento fechado dos moradores que preferem a 


\section{segurança do apartamento à convivência com os vizinhos, estabelecendo muitas vezes contatos superficiais e rápidos diferentes, por exemplo, das amizades do interior.}

\section{As formas de sociabilidade no Crusp correspondem às da cidade grande}

O que eu acho estranho é que as pessoas se isolam um pouco nos apartamentos. Logo quando eu cheguei aqui eu achava muito esquisito, passavam as pessoas pelo corredor assim que eu já conhecia a algum tempo e elas não se cumprimentam, não sei talvez também seja um costume muito do interior, mas mesmo assim eu vejo que a maioria das pessoas vieram de fora e de regiões pequenas, mas acho que elas criam uma proteção assim se fecham.

Não existe aquela coisa de, também é porque eu sou do interior, aqui em São Paulo isso não existe em lugar nenhum, sei lá de vizinho, de combinar coisas ou se encontrar, os meninos jogarem bola. Eu acho que os meninos até jogam bola aí no final de semana, mas as meninas não, a gente fica em casa assistindo televisão, vai sair pra andar de bicicleta, vai ler, vai na praça do relógio, mas tem isso de ruim que eu acho que é você ficar muito remetido.

As amizades não são as mesmas, naturalmente, não são as mesmas que você tem no seu bairro, na sua família, as amizades são muito superficiais, eu sempre percebo um certo distanciamento, uma certa frieza nos relacionamentos e somando isso mais o isolamento do CRUSP, eu acho que fica uma ambiente muito desagradável pra se viver.

Tem uma coisa que eu acho um pouco pior, são os traços de individualidade que as pessoas carregam dentro do CRUSP porque apesar de parecer uma super comunidade, não é bem assim entendeu? Você tem pessoas que são mais fechadas, por mais que você tenha vários colegas, você diga oi tudo bom nesses corredores, almoce, jante quando cada um fecha a sua porta é ali e acabou. É claro que isso não é uma característica generalizada, mas grande parte dos moradores tem essa postura então é por isso que outros moradores reclamam, acontecem brigas nos apartamentos, as pessoas se fecham realmente, o motivo eu não sei explicar pra você o quê que é realmente então isso é uma desvantagem muito grande que eu vejo.

Alguns moradores responsabilizam outros por problemas de convivência, explicando que o fato do CRUSP ser uma moradia passageira pode dar aos moradores a noção de que não devem cuidar do espaço. 


\section{Os moradores não têm respeito para com o espaço coletivo}

Se existe um problema é por parte dos moradores mesmo, da falta de consciência mesmo deles e de realmente achar que aqui é um lugar passageiro, que eles podem fazer o que quiser com o prédio, com a cozinha, com o apartamento eu acho que é isso.

Eu acho que as pessoas deveriam ter no mínimo senso que se a cozinha, por exemplo, é comunitária, você vai limpar o quê você sujou, você vai catar a cebola que você descascou, você pegar a casca e jogar fora e não acontece. Tem dia que você vai na cozinha, de final de semana você não tem coragem de cozinhar porque ta sujo. E dia de semana não, ta limpinho porque a moça que trabalha no prédio limpa todo o dia, ela limpa o corredor, ela recolhe o lixo, mas de final de semana não tem funcionário então, a gente deveria fazer a nossa parte o que não acontece.

Outra dificuldade na convivência com as pessoas é o não respeitar horário esse tipo de coisa.

São alguns poucos moradores que não cuidam do espaço como deveriam e que é o quê também dá essa má fama ao CRUSP de ser um lugar ruim.

O barulho incomoda não somente porque alguns aumentam o volume da voz ou fazem festas, mas porque as paredes não têm isolamento acústico.

\section{O barulho incomoda os moradores}

De desagradável é o barulho, me desagrada muito. Durante a noite muita gente fica gritando de um bloco pro outro isso atrapalha essa noite mesmo de madrugada, umas duas horas gritaram muito.

As paredes são de gesso, então a gente escuta tudo que as outras pessoas falam, essas gritarias que eles fazem de madrugada que não deixa ninguém dormir. Não adianta você reclamar porque nunca fazem nada, isso é que é o ruim, pra mim o pior é o barulho.

Lá [no [CRUSP] é uma coisa meio que egoísta, eu não tenho horário eu faço o que eu quero. É aquela coisa como eu não tenho aula eu não me preocupo com quem está do lado e vai acontecendo, chama neguinho vai fazendo [uma] comemoraçãozinha lá, uma festinha cá 


\section{O CRUSP parece alegre, mas é um ambiente perturbador}

Vira e mexe tem baderna lá, é gente gritando, no meio da madrugada sai correndo, tem gente que sai correndo pelado no meio da madrugada e [ninguém] vai fazer nada. Então, tem gritaria, tem um lá que a gente acha engraçado porque no meio da noite ele abre a janela e grita: "Calhorda!" e fica gritando. Aí o povo vai abrindo a janela e: "Seu Filho da Puta", e vai assim, aparece o prédio inteiro. Acorda e vai gritando e a gente lá no meio, mas se for ver bem [pra quem é] de fora é um ambiente meio que alegre, mas não é assim é meio que perturbador, eu não gosto muito. Eu sou meio careta para essas coisas

\section{É negativo o fato dos moradores não valorizarem a moradia}

Alguns moradores, eu acho, não tem consciência do que é poder ter uma moradia assim a disposição, não valorizam tanto.

\section{A sujeira incomoda}

Eu acho que o corredor é muito sujo, aquele lá em baixo, aquele corredorzão, também eu não sei porque é que foram colocar esse piso branco, porque reformaram e colocaram esse piso branco, mas é tudo questão de estética que eu acho que incomoda.Você morar num lugar sujo que você vê a coisa suja incomoda e o lixo que os moradores jogam pela janela, jogam no corredor, tem festa no outro dia você vê cheio de copinho e papel no chão.

\section{A moradia no alojamento é muito precária}

Eu vivi no alojamento, morei no alojamento dois três meses até sair o resultado e era um quarto com vinte pessoas, então você não podia acender a luz depois das 11 , você não tinha espaço pra você estudar tinha que ir para uma sala de estudos no prédio mais também difícil, a primeira cozinha ficava no primeiro andar, ficava longe. Então, isso perde totalmente a liberdade, não tem onde por as coisas. As minhas coisas viviam dentro da mala porque meu guarda-roupa não cabia tinha que dividir.

Num outro alojamento tem acho que são 10 pessoas no quarto. E mesmo, no quinto andar tem um alojamento pequeno pra 12 pessoas, são três quartos e ficam quatro pessoas em cada quarto então tem espaço um pouco maior pra guardar as coisas e são só quatro pessoas então é mais fácil de lidar do que com 
10, 12 pessoas. Eu não gostei muito de lá pela falta de privacidade que tinha.

Segundo os alunos, no CRUSP existem regras, mas que não precisam ser cumpridas, eles se sentem livres da autoridade paterna e sem nada para ser colocado no lugar. Esse excesso de liberdade acompanhado da falta de autoridade não é visto só como algo positivo, apontando-se que a conseqüência é o não aprendizado de respeito ao espaço público.

\section{Viver no mundo do CRUSP é viver sem regras institucionais estabelecidas}

Eu acho que aqui no CRUSP eles dão bastante liberdade em todos os termos, não só em termos de droga. É bem livre mesmo, porque não tem quem controle, é um lugar livre, [onde] as pessoas fazem o quê elas querem. Existe uma coisa no CRUSP que é todos poderem ser o quê quiserem. Então essa sensação de liberdade talvez incite a experimentar coisas novas. Pessoas novas que nunca usaram devem sentir vontade de saber como que é e acabam embarcando nesse tipo de postura, de consumir drogas. É como se você tivesse num mundo à parte [essa é] a impressão que a gente tem, por isso que tem tanta gente que não consegue sair daqui

Mas é claro que assusta quando você chega aqui. Nossa tudo é permitido. Aqui de certa forma você não tem nenhuma autoridade, você tem iguais a você e quando a autoridade vem você não precisa ouvir se você não quiser. Tipo se você está dando uma festa, os caras vêm e falam pra você abaixar a música se você não quiser você não abaixa e eles não podem fazer nada com você porque você é universitário, você está dentro da Universidade de São Paulo, afinal ninguém deve te reprimir aqui dentro. É um clima propício [para] essa liberdade que está muito firme na cabeça de todos que entram aqui. Quando você entra aqui é isso que você sente, você fala putz que legal eu saí da casa do meu pai ual!!

Essa [é a idéia] dos alunos que aqui chegaram junto comigo era uma coisa meio de liberdade diante da autoridade paterna e de desprendimento, um lugar de autonomia e pra mim eu estou na minha aprendendo a trabalhar. Essa liberdade eu sempre fui obrigado a ter. E de repente eu vi o pessoal fazendo um tipo de coisa que eu falava pra mim não faz sentido. Não é isso que vai me fazer mais livre.

[É] um problema [porque] não tem ordem estabelecida aqui dentro, às vezes. [Há] um excesso de liberdade e as pessoas acabam ultrapassando alguns limites assim, por exemplo, as pessoas entram [e] elas não têm consciência de que o espaço que elas estão usando é público e que um dia elas 
vão embora e tem que deixar o espaço legal pra outras pessoas virem morar.

\section{Não há ordem estabelecida no CRUSP}

A questão negativa é o foco de porcaria que tem nesse lugar. Tem muito usuário de drogas e muita bagunça, não tem uma ordem estabelecida aqui no CRUSP, as pessoas acham que elas têm direito de fazer qualquer coisa, elas têm dificuldade em definir esse caráter público do CRUSP, então qualquer argumento é ah! isso aqui é público. Eles não têm bem claro o que é público e o que é privado, qual a noção definida de público. Então eu acho muito problemático morar aqui, eu não gosto não, eu acho ruim.

\section{Alguns alunos não identificam nenhuma especificidade no CRUSP, referem que é como morar em qualquer prédio, outros acreditam que a variação entre positivo e negativo se refere ao apartamento e outros aos blocos.}

\section{Morar no CRUSP é como morar em qualquer prédio}

Aqui tem as inconveniências de morar em um prédio, que eu acho que todo prédio tem, alguns menos outros mais vai depender da vizinhança que você encontra. Acho que em qualquer prédio você pode ter uma vizinhança legal ou alguns vizinhos que fazem mais barulho

\section{O positivo ou negativo de morar no CRUSP varia de apartamento para apartamento}

[O positivo ou negativo de morar no CRUSP] varia muito de apartamento pra apartamento depende com quantas pessoas você mora. Eu comecei morando[em um apartamento desse bloco] que até que era legal o pessoal, mas que tinha apartamento do lado assim que eu não moraria, se eu tivesse lá eu fazia alguma coisa pra sair porque não dava. 


\section{Quanto mais antigos os blocos mais problemáticos}

Eu acho que o meu bloco é o mais sossegado, eu acho que o $\mathrm{F}$ é o pior, porque ali é o pessoal mais antigo, você vê assim o nível do pessoal, você dá uma olhadinha você já vê que não é muito aquele pessoal mais sossegado. [Pela] aparência, você percebe que o pessoal já vai mais pra esse lado, sabe? Eu acho que esse aqui é um dos [blocos] mais quietos. Principalmente por serem alunos mais novos na faculdade, o bloco é novo, os moradores faz pouco tempo que tão aqui. Então eu não sei se é o geral dos blocos do CRUSP, mas esse bloco eu acho que é bem sossegado. Eu acho que cada bloco tem suas peculiaridades, o bloco A, por exemplo, é só de mães, não sei como é o uso lá, o que acontece, eu não posso generalizar.

Os alunos se queixam de não ter a quem recorrer quando tem algum problema na moradia. Segundo eles a COSEAS, órgão da universidade responsável pelo gerenciamento do CRUSP, demora em resolver problemas de diversas ordens na moradia como a falta de energia ou água, inclusive omitindo-se em relação ao tráfico de drogas, como se ele fosse se resolver por si mesmo. A guarda universitária também, quando chamada, não soluciona os problemas de acordo com a expectativa dos alunos, chegando ao extremo de recorrer à polícia. Dessa forma, sentem que a administração do CRUSP não faz nada por eles.

\section{A COSEAS demora em resolver problemas de diversas ordens}

A minha queixa maior é em relação a organização mesmo, não ao CRUSP em si, nem tanto aos moradores, mas aos órgãos que organizam e que fiscalizam o CRUSP. Esses eu acho que deixam a desejar. Por exemplo, agora já faz tempo que não acontece, mas às vezes acaba a energia elétrica porque caiu um disjuntor, daí assim leva 5 horas pra alguém ir lá e levantar o disjuntor é um botão que alguém tem mexer, mas não tem uma mobilização da organização pra ir lá e em 5 minutos resolver o problema. Também se você precisar de alguma coisa e você for até o COSEAS, de algum conserto, alguma coisa, demora demais, você tem que conviver com o problema por um tempo até eles fazerem ou você mesmo resolve ou acaba desistindo. 
Antes faltava água às vezes mas a muito tempo não acontece já parece que realmente eles deram uma melhorada nisso, mas a gente percebe ainda que tem um descuido com essas coisas e desse lance da fiscalização.

É um apartamento ou outro por andar às vezes um ou outro por bloco assim que tem algumas pessoas que o COSEAS também não toma providência, que usam drogas, depredam o lugar e não respeitam o silêncio esse tipo de coisa.

\section{A instituição se omite para resolver problemas na moradia principalmente os relaciona dos com as drogas}

Olha, eu acho que [o CRUSP é um ambiente] livre, não só relacionado a drogas, mas quando acontece alguma discussão aqui entre moradores, algum problema assim, a maioria das vezes eles chamam a guarda universitária, mas a guarda universitária não tem uma atuação. Eles chegam conversam pedem pras pessoas se entenderem no diálogo em alguns casos chega-se ao extremo de precisar chamar a PM, daí faz Boletim de Ocorrência, vai pra delegacia, mas é difícil isso acontecer.

[Quando] a guarda universitária passa o cara, no CRUSP não na USP toda, [está] fumando[ou] fazendo qualquer coisa [o guarda] não pode fazer nada [ele] não faz nada. [Portanto], é livre o uso, de fato é livre não é uma imagem, não é uma ilusão, de fato é livre o uso, as pessoas usam, todos sabem, as assistentes sociais sabem quem usa, quem não usa de onde sai, só que não acontece nada, [também] não sei se devia acontecer [alguma coisa].

Eu acho que é verdade como eu já te disse é muito fácil a guarda vir aqui e pressionar a gente porque a gente está fazendo barulho numa festa quarta-feira, tudo bem a gente está fazendo uma festa numa quarta-feira, aniversário do nosso amigo, a gente está forçando a barra, mas é muito fácil chegar aqui e reprimir a gente, [porque eles] sabem com [quem] eles estão mexendo, entendeu? Mas com o traficante com aquele cara lá mesmo pesadão, todo mundo sabe que rola ninguém vai mexer [com ele].

E outra é claro, não estou falando que a gente está inocente nessa história, tem o traficante aqui porque a gente compra, mas é uma coisa pesada, a gente sente que certas coisas complicadas acontecem aqui principalmente [por causa] desses traficantes que a gente sabe que tem aqui, parece que é uma coisa que fica assim meio de canto é um assunto que ninguém fala então deixa quieto como se fosse se resolver.

[Quanto] as assistentes sociais [eu acho que] aqui tem um problema, elas acham que se elas repreenderem de alguma maneira vão estar exatamente prendendo, diminuindo a 
liberdade de expressão das pessoas. Elas sabem que existe o uso de drogas], e eu acho que se elas sabem, elas sabem quem é e onde fica a gente sabe que o bloco F é o maior ponto, que tem traficante lá dentro, porque não tentar falar, conversar, tentar fazer alguma coisa lá.

O CRUSP parece livre por essas coisas, pelo lado da administração a gente tem a impressão que [eles] não fazem nada e pela gente [mesmo] que permite que isso aconteça.

Os alunos apontam uma série de irregularidades no ingresso no CRUSP, no controle sobre a entrada, a permanência e a saída na moradia e na ocupação irregular das vagas. Essa falta de controle gera entre os alunos sentimentos de hostilidade para com moradores que vêm de outros países, trazendo suas famílias. Assim, há um discurso pesado de crítica à forma como as vagas são distribuídas, apontando-se desde arbitrariedades na definição do número de pessoas por apartamento até uma certa lentidão na tomada de decisões, prejudicando alunos que estão na fila de espera.

\section{Há problemas na forma como são distribuídas as vagas}

Eu acho que a primeira coisa que tem de negativo é a forma como eles criam o número de vagas por apartamento. São três vagas, então sempre cria uma relação assimétrica de poder, sempre são dois e um, dois e um, um e dois, quando o apartamento tem harmonia as pessoas vivem bem, mas se tiver qualquer desavença é sempre dois e um. Nunca eles colocariam quatro ou dois pra morar porque tenho a impressão que isso é uma jogada, isso atrapalha um pouco, nesse sentido, cria uma relação de poder mesmo, de anti-democracia. Aqui a regra do CRUSP é que duas pessoas podem tirar uma, entendeu?

Além disso, sempre tem umas irregularidades, como eu sou de fora, eu precisava da vaga e a gente sabe que tem muita gente lá dentro que está lá, mas que não foi por inscrição que simplesmente entrou e ficou. [Tem também] aquele negócio, do pessoal [que não] mora no CRUSP [mas] que fica lá, é hóspede irregular que a gente fala, muita gente que vai e fica dois, três dias na casa de um, na casa de outro, tem a casa própria dele, mas como é łem festivo o ambiente lá, aí o pessoal vai e fica mesmo tem coisa lá que a gente [nem] sabe.

[Comigo aconteceu] mais ou menos assim eu ingressei de transferência por isso que eu entrei o ano passado na USP, mas já eu estou no terceiro ano porque eu peguei alguns créditos, fazia a Federal do Pará. Aí eu vim morar aqui então 
eu não tinha muito pra onde ir e logo no começo eu consegui uma vaga de hóspede só que num quarto sozinho pra mim num outro bloco. Aí eu ia ficar provisoriamente, porque o COSEAS tinha uma data, estavam em reforma os alojamentos e tinha uma data pra alojar os alunos e eu vim um pouco antes dessa data.

Então, como disse, não tinha onde ficar e por sorte eu consegui ingressar num outro bloco com dois rapazes um era da Poli e outro fazia física. E aí foi uma moradia excelente. Muito boa, a gente se dava muito bem, a gente fazia esquema de limpar o apartamento, de comprar água estava tudo sempre limpinho, arrumadinho e eu estava muito bem só que eu tava como hóspede. Aí a assistente social me falou: "você está concorrendo a vaga você pode ou não conseguir' e aí por azar quando veio a primeira lista, que é essa que sai em maio eu não fui contemplado com a vaga.

Só que aí o meu nome não saiu eu fiquei bem pertinho inclusive abriram 147 vagas e a minha classificação foi 150 , eu era o terceiro da segunda lista e depois eu soube que pessoas desistiram já na primeira lista, mas o COSEAS não teve aquela dinâmica de vamos colocar mais gente, eu poderia ter ficado no lugar onde eu estava.

Foi muito engraçado porque as pessoas estavam saindo do alojamento pra ir para as vagas e eu estava fazendo o inverso, estava saindo de uma vaga muito boa e estava indo pro alojamento, e lá foi meio complicado.

\section{Ocupação irregular gera falta de vagas oficiais e sentimento de hostilidade}

Tem muita gente que precisa morar no CRUSP e não pode porque não consegue a vaga por causa dessas pessoas que ocupam irregularmente e fazem mal uso do espaço.

É principalmente o pessoal de fora africanos, angolanos, estrangeiros que vêem e conseguem não sei como, a primeira vaga tudo bem é deles, tem direito, mas depois vem com a família inteira e ficam morando no CRUSP. E uma coisa, eles tiram as nossas vagas, assim como o pessoal que simplesmente invade também tira. Acontece para todo mundo ver e ninguém faz nada.

Para reforçar o estigma já apontado pelos entrevistados em outro momento, os alunos referem que a sociedade tem uma visão muito distorcida sobre o CRUSP e sobre os moradores e que eles sofrem preconceito quando dizem que moram no CRUSP, mesmo dentro da universidade. $\mathrm{Na}$ opinião deles, a existência de uma série de problemas no CRUSP não justifica a visão 
social que se tem da moradia. Para agravar, a mídia tem tido um papel importante na divulgação apenas de fatos negativos que acontecem no CRUSP e mesmo na criação de fatos.

Assim o CRUSP é visto como um espaço bagunçado e perigoso, "um espaço cumprido, cheio de beliches, como num campo nazista". Trata-se de um julgamento moral socialmente disseminado que imputa ao projeto de vida de alguns estudantes, que questionam o modo de vida dominante, uma função de "desvio", inclusive valendo-se da idéia de que os moradores apoiam atividades "desviantes" como é considerado o uso de drogas por exemplo. Assim, os estudantes moradores são rotulados como miseráveis e vagabundos, há um "preconceito de classe".

\section{A visão social do CRUSP desqualifica a moradia: espaço bagunçado e perigoso}

Todo mundo já tem uma idéia de república, qualquer tipo de república já falam que é uma bagunça, que é uma baderna, que não sei que. Mas as pessoas falam muito do que elas não conhecem porque eu quando vim morar aqui pintavam pra mim um lugar totalmente horrível, que eu fiquei com medo de vir morar. Mas a partir do momento que eu vim pra cá vi como era e desfiz totalmente essa visão. [Hoje] eu não acho que seja uma assim coisa aberta todo mundo que entra usa droga, não vejo nada disso. Ainda têm esse mito quando eu falo que moro no CRUSP as pessoas falam: nossa mas deve ser uma zona lá [ou então] já perguntam se é um bacanal, se todo mundo usa droga, se é tudo sujo. Falam do que não sabem, não vejo que aqui seja diferente de outros lugares. Muita gente nunca veio aqui as pessoas acham que é um espaço cumprido, cheio de beliches como num campo nazista.

E sei lá acho que essa idéia do CRUSP como um [lugar] desorganizado é por ser a maioria do pessoal da FFLCH e por a gente ter uma concepção de mundo diferente daquela que é funcional e orgânica. O pessoal [também] acha que a gente faz questão de não se enquadrar num mesmo estilo de vida que é o padrão pra eles, sendo que não é verdade. A gente questiona na busca de um aperfeiçoamento social mesmo, pra quebrar preconceitos porque a sociedade tende que ser hipócrita. Por isso que o uso de drogas é disseminado por aí fora, porque não vêem isso sem preconceito, antes de saber o que se passa, qual a razão, é como se diz, a análise é mais moral do que objetiva aí é essa a questão. Talvez [porque] pessoal da FFLCH em 
geral encare isso de uma forma mais objetiva então eles acham que a gente apoia o uso de drogas e usa também quando não tem nada a ver assim.

$\mathrm{Eu}$ acho que [existe] uma idéia errada até hoje sobre o CRUSP muito errada e que tem muita gente que mora aqui e que não sabe lidar com isso também, que não se sente bem em falar que mora aqui. [Além disso], já saiu várias vezes na televisão pesquisas mostrando que na USP a incidência de usuário de drogas é muito grande. Então morar numa república, onde tem estudante [eu] acho que [gera essa idéia].

[Mas por outro lado] apesar de haver contestações, de dizerem não o CRUSP é um lugar super tranqüilo, onde as coisas correm normalmente, não é verdade isso, não é realmente. Existem blocos conturbados, existem apartamentos muito conturbados, então o que eu acho que ocorre é uma generalização. Por existirem grupos que se tornam conhecidos por utilizarem ou por pessoas ouvirem histórias das pessoas que usam e que são do CRUSP ou que moram no CRUSP e que é uma bagunça então se tem uma idéia de que todo o CRUSP, todos os moradores são pessoas usuárias de droga, vivem em baderna, vivem na esbornia. [Isso] é também uma atitude super extremista eu acho que no fim das contas acaba sendo dividido, realmente existem esses usuários, mas o CRUSP não é só um lugar onde se usa droga, existem pessoas que ralam demais, trabalham o dia inteiro, se esforçam pra manter o curso ali em dia, ajudam suas famílias, quer dizer pessoas sérias também, não dá pra você falar assim: o CRUSP só tem vagabundo isso não é uma idéia correta.

\section{A visão social do CRUSP desqualifica o morador: miserável e vagabundo}

Eu acho que muita gente na não conhece na verdade o CRUSP. Então acho que as pessoas precisam conhecer um pouco mais o CRUSP antes de falar, conhecer as pessoas do CRUSP, não digo que não tenha problemas lá eu não sei como é que é nos outros, mas da minha experiência eu não posso reclamar de nada.. Então eu acho que as pessoas imaginam, mas elas não conhecem realmente e a gente vê que mesmo na nossa sala, nos outros anos o pessoal que mora lá, existe até um certo preconceito em relação ao CRUSP.

Tem gente que mora lá e não precisa realmente, então tem isso também, mas o quê as pessoas pensam é que, ah! aquelas pessoas que moram lá são miseráveis. Então tipo rotulam, só usa droga, fica o dia inteiro, passa a madrugada inteira fumando, não faz nada na vida. Está lá porque o pai pode pagar, mas fica lá porque está abusando do governo, deve ter gente que faz isso, a gente sabe que tem, se apóia no governo, mas assim é esse tipo de rótulo em relação à droga $\mathrm{e}$ 
em relação as condições financeiras, mesmo você sente isso. E tem pessoas que as vezes a gente convida, porque tem estágio, alguma coisa, é mais fácil, ali no $\mathrm{HU}$, as vezes posa em casa numa boa, mas tem gente que evita ao máximo. Está precisando, mora muito longe, chega cansado, você convida e você vê que a pessoa tem o pé atrás por causa do local, então não conhece mesmo.

Eu acho assim que tem um estigma muito grande com o CRUSP, assim com os moradores do CRUSP, a partir do momento que você fala que mora no CRUSP as pessoas já te olham de uma forma diferente.

$\mathrm{Na}$ verdade eu acho que aí há uma coisa meio de preconceito de classe, mais ou menos isso. Na verdade eu acho que há uma população que entra na USP e que é classe média, média pra alta, que usa droga só que não está acostumada com pobre a grande diferença é essa.

$\mathrm{Na}$ verdade pelo que eu vejo nas festas da biologia, da medicina, da engenharia acho que não difere quanto ao uso de drogas não difere muito daqui não. Na medicina muito pelo contrário lá é uma coisa exagerada, lá dá medo, dá medo, mas eu acho que, na verdade, é mais um preconceito de classe mesmo, porque querendo ou não a maioria da FFLCH daqui é a maioria pobre. Acho que é mais isso mesmo. O negócio está mais aí do que o uso de droga pela USP eu acho que, pelo que eu vi nas festas, na ECA não difere muito do CRUSP não.

A mídia reforça o preconceito, num mecanismo de: divulgação de acontecimentos que desqualificam os moradores; de omissão da informação que qualificaria positivamente os moradores e na generalização leviana de acontecimentos que são específicos e particulares.

\section{Os acontecimentos negativos viram notícia, os positivos não}

[É sempre assim] quando acontece alguma coisa muito fora do comum, em qualquer lugar vira notícia, mas as coisas que acontecem do bem nunca vêem. Em muitos casos você tende a ver somente o lado negativo das coisas quer dizer é muito mais fácil [as] coisas negativas virarem notícia do que coisas positivas aliás a mídia faz um trabalho fabuloso nesse sentido de notícias negativas, assuntos que são de cunho negativo eles se tornam pauta obrigatória e as publicações já atingem um grande número de pessoas, isso contribui realmente para que o CRUSP tenha essa imagem [negativa].

Eu me lembro que até que saiu umas reportagens em jornal dizendo de pessoas que usavam maconha e rasgavam a bíblia e faziam cigarros de maconha usando a bíblia quer dizer 
isso chocava as pessoas lendo o jornal, eu retomo a idéia que eu falei antes você não pode generalizar.

As idéias sobre o consumo de drogas na moradia são controversas e parecem acompanhar o conjunto de idéias preconcebidas sobre a moradia. Muitos alunos referem que o consumo de maconha no CRUSP é freqüente e até mesmo perceptível pelo cheiro, no entanto, no que se refere aos índices de consumo as opiniões são bastante contrastantes pois há quem diga que o consumo é alto, quem diga que é baixo embora traga problemas e há quem apenas refira a existência de rumores sobre o consumo de drogas pesadas.

\section{O uso da maconha é comum e perceptível pelo cheiro}

Maconha é absolutamente comum, não é preciso você andar a noite pra ver, durante o dia, em qualquer lugar é no corredor é nos apartamentos acontece muito. Eu não sei se você teve oportunidade de ver no CRUSP aqueles corredores imensos a gente vai passando no meio, nossa, aquele cheiro de mato é coisa básica, vai passando assim, se for de um lado ao outro é capaz de a gente ficar meio lesada quando chegar no último, o pessoal fuma lá direto, é complicado.

A gente sente o cheiro, o cheiro quando a pessoa fuma vem pela área de ventilação do prédio, pelas janelas, hoje mesmo por exemplo, eu senti não tem como disfarçar muito. $\mathrm{O}$ cheiro da maconha é muito forte e um dos pontos negativos também é esse, de vez em quando aparece o cheiro no banheiro que vem pelo cano central compartilhado, vem o cheiro pelo corredor, incomoda um pouco.

Fora isso lá em baixo às vezes ficam uns grupinhos sentados conversando ali perto do DCE ou aqui perto da conveniência mesmo você vê, você passa perto você sente o cheiro, sabe que eles estão fumando, mas estão na deles estão ali.

Maconha é em tudo, por exemplo, quarta-feira teve o eclipse da lua, foi todo mundo do CRUSP pra lá ver a lua e tal eu cheguei assim e eu me assustei, não ta rolando nenhuma maconhinha? Mas aí foi cinco minutos e eu já senti o cheiro da fumacinha e tal. Aí estava um pessoal usando lá, até alguns amigos, conhecidos aqui eles estavam usando assim aí eu cumprimentei. oi e tal, não foi nada. 


\section{O CRUSP é um local onde há alto índice de uso}

É aqui no CRUSP cara é complicado porque a gente sabe que corre solto, tem traficante morando aqui. $\mathrm{O}$ negócio corre assim, a gente está sentado às vezes vendo televisão sente a maconha, o cheiro da maconha, a gente sabe que o pessoal consome e consome coisa pesada aqui, consome muito é um mercado interessante, tanto do pessoal daqui de dentro como tem gente de fora que vem comprar. Então é assim meu, a gente sabe que muita gente usa, mas é uma coisa que está aí e é meio complicado.

E eu considero alto o uso de drogas aqui, eu acho que é bastante pelas pessoas que estão aqui, muita gente não é daqui e tal, mas eu acho que é um problema. $\mathrm{O}$ uso de drogas no CRUSP é bastante não digo visível, mas eu sei que existe e muito, o consumo é, na minha opinião, alto e bem freqüente

\section{Há pouco uso}

[O uso é] pouquíssimo eu só conheço esse apartamento acho que só esse apartamento no CRUSP inteiro assim. [Conheço em três blocos, mas um deles] é tenebroso assim. Esse bloco é um prédio mais velho, tem um pessoal mais antigo, então tem umas histórias lá, só que é mais bebida [sobre] drogas eu não sei.

Tanto é que se for fazer uma pesquisa entre os Cruspianos, os moradores do CRUSP a maioria são não usuários é que geralmente o pessoal inverte. Só porque têm alguns, [porque] foi achado maconha, o CRUSP é infestado de maconheiros. Acho que não é por aí.

\section{Há pouco uso, mas causa problemas}

A maioria você sabe que não usa, só que os que usam aqui, dentre os que usam tem um grupo que gosta de se expressar muito com grito, se você ficar uma noite aqui e você pegar um dia de sorte você vai ouvir a gritaria, os caras gritando. Tinha um apartamento histórico que eu morei um ano, o cara estava há 10 anos, agora ele saiu, nossa ele usava muita droga, então ele quebrava tudo, as luzes do apartamento e quando eu vim pra cá ele gritava, ficava gritando pro CRUSP todo ouvir. 


\section{Há rumores sobre o uso de drogas pesadas no CRUSP}

Acontecem casos de uso de drogas pesadas tem gente que fala que tem drogas mais pesadas [como] crack, mas eu nunca vi ninguém fumando crack por ali

\section{Não tenho conhecimento se há drogas mais pesadas no CRUSP}

Quanto à droga mais pesada, que chamam de mais pesada eu num tenho conhecimento [se há no CRUSP].

Notadamente muitos alunos referem que o consumo de drogas não se relaciona ao fato de morar no CRUSP, que não há um oferecimento. Novamente o preconceito é apontado como mecanismo de apartação dos moradores, uma vez que os moradores são pessoas que têm que trabalhar e estudar para sobreviver e se esforçam muito para isso, desdobrando-se em tarefas para manter bons padrões de estudo.

\section{O uso de drogas não se relaciona ao fato de morar no CRUSP}

Eu acho que quem vem muito de longe, de fora, [mas] que pode ser influenciável pode ser que ele venha a consumir porque está aqui, mas se tivesse em outro lugar morando com outros estudantes chegaria ao consumo da mesma maneira. A única coisa é que as pessoas se permitem um pouco mais aqui porque eles estão longe de casa e tudo mais, mas acho que nada que as pessoas não fariam.

Acho que não é o ambiente que vai fazer a pessoa pode ser que a pessoa [pense] Ah! estou entediado não sei que lá mais. Que diferença faz entre aqui e a república é que aqui é um espaço muito igual e a pessoa talvez se canse com isso, tudo muito certinho, tudo muito isolado, o que cria um tédio na pessoa, mas acho que isso não influencia tanto quanto morar em outra república dentro de São Paulo pra poder estudar na USP. Não tem muita diferença, não talvez só essa coisa da pessoa estar chegando e conhecer o lugar, conhecer o espaço e se iniciar por exemplo nas drogas, mas não é o CRUSP que inicia a pessoa, a pessoa que em qualquer lugar faria isso.

Acho que [o CRUSP] não propicia [o uso de drogas], acho que a pessoa, ela vem de um lugar com seus valores é ela que vai se deixar ser conduzida ou não. É lógico que a pessoa 
chega um pouco perdida e a gente tem que levar isso em consideração, ninguém chega aqui espertão, ligado. É bixo, está chegando agora, chega meio assustado, o sentido de bixo é esse na verdade, é o sentido da pessoa que chega meio assustada, às vezes precisa de uma força, depende de quem apoia pode ser que ela comece a se prejudicar, mas depende dos valores dela se ela vai ser influenciada pela ajuda dos outros.

Eu vim lá do interior pra estudar aqui não é porque eu recebi uma casa pra eu morar de graça que eu vá me drogar e ficar aqui o dia inteiro me drogando. Eu acho que não é o caso, mas eu não acho não que o lugar facilite ou inspire esse tipo de coisa eu acho que não. Eu acho que não tem muito a ver porque acho que as pessoas que estão aqui estão porque precisam financeiramente e a gente não precisa só de morar e comer a gente precisa de viver e pagar xerox, então o pessoal trabalha e estuda [e no] final de semana o pessoal sai vai beber.

Eu não vejo muita diferença entre o CRUSP [e] os outros condomínios, não vejo muita diferença. Tem moradores que tem problemas tanto aqui como fora em outros condomínios às vezes até mais, até maiores, eu não saberia destacar um fator que confirme essa afirmação de que o CRUSP propicia o vício, eu acho que não.

É o que eu falei, eu acho que [em] qualquer lugar a pessoa é livre, hoje em dia [em] qualquer lugar.

Eu acho que depende muito mais das suas amizades fora do CRUSP mesmo. Por exemplo, eu nunca usei, nunca pretendo usar e moro aqui. Pode ser que ele encontre os amigos aqui pra continuar, mas não que seja aqui a origem do problema.

$\mathrm{O}$ fato de eu estar morando aqui com pessoas que fazem uso, pessoas que até vendem, traficam sei lá, isso não vai propiciar que eu use porque é uma coisa que eu não curto e não vou fazer porque os outros fazem então é de cada um mesmo, mas a liberdade ela existe, [mas aqui] você não vê o pessoal oferecendo. Não é que nem no Rio de Janeiro onde o pessoal passa vendendo na rua assim com fuzil na mão, eu nunca vi ninguém armado aqui nem portando droga visivelmente eu nunca vi e nunca me ofereceram, nem soube de alguém pra quem foi oferecido droga uma vez, nunca ouvi falar. Ninguém fica chamando o outro a ser usuário, então usa quem quer, também ninguém fica usando em qualquer lugar.

$\mathrm{Eu}$ acho que se você for pegar os estudantes da USP e colocá-los em outro conjunto residencial o índice vai ser o mesmo. É que aqui juntou todo mundo é como se estivessem todas as repúblicas de estudantes num espaço só e aí você pudesse observá-las de uma só vez, aí seria fácil de você fazer uma estatística, tipo ali todo mundo usa droga é o que acontece. Eu vou em festa de "república" e não tem uma festa em que eu vá e que não tem alguém fumando maconha e aqui 
[o que] acontece é que as repúblicas estão juntas, então fica mais fácil, mais evidente de você observar isso.

Ainda no que se refere especificamente ao consumo de drogas no CRUSP, pode-se notar que alguns alunos, desde o ingresso na moradia, trazem na bagagem preocupações com o consumo. Dessa forma, a atitude deles é a de procurar um espaço livre das drogas. Já no campo das explicações encontradas para a existência de algum consumo no CRUSP propriamente dito há um leque que vai desde o fato de haver um livre acesso de não-moradores ao CRUSP (as pessoas vão lá para usar), uma vez que a polícia não poder entrar no campus, até um acesso às drogas considerado muito fácil.

\section{Selecionou apartamentos sem usuários de drogas}

Como eu fiquei pra segunda lista só tinha os lugares bomba pra entrar. Então teve um apartamento que eu bati que o cara abriu e estava tendo uma rodada de fumo, era uma boca de fumo o lugar e aí o rapaz falou que na vaga já tinham hóspedes e que o hóspede não ia sair do quarto se eu quisesse eu podia ficar na sala, sendo que a vaga era minha por direito era minha, aí eu falei tudo bem fica aí na boa que eu vou procurar outra vaga.

[Em] outra [vaga] eu vi fumaça saindo da janela então eu nem bati, aí o lugar menos pior que eu encontrei foi esse aqui. Aí eu ingressei aqui, eu vi que era um lugar que a galera não curtia droga me perguntaram se eu usava drogas e tudo então eu já achei um lugar a principio legal.

Então eu moro com uma pessoa que graças a Deus é super careta, que é uma preocupação quando a gente vai ingressar no CRUSP [dividir o apartamento com] algum maloqueiro, alguma pessoa bem "triste". Eu [já me] mudei duas vezes. [No primeiro apartamento em que morei] eles não faziam uso de álcool e drogas, mas eram pessoas muito difíceis, [tão] difíceis que eu resolvi [me] mudar.

\section{Pessoas de fora não são impedidas de vir usar droga no CRUSP}

Então eu acho que de certa forma isso [o uso de drogas ser livre no CRUSP] até é verdade porque vem muita gente aqui pra usar drogas. Muita gente vem de outros andares pra cá pra fumar, vem gente de fora da USP pra fumar aqui dentro. [Tem também] a pessoa que tem medo de fumar lá em baixo, 
de cheirar lá em baixo de alguém ver e tal, ela vem pra cozinha cheirar porque sabe que ninguém vai impedir a entrada dela no CRUSP, nos prédios e tal. Ninguém vai chegar lá na cozinha e vai expulsar, sai daqui porque você ta usando drogas, isso não acontece.

Isso é uma coisa que, eu já naturalizei mas alguém que não mora aqui, que não fica aqui, porque eu fico aqui vinte e quatro horas por dia, alguém tomaria um choque, mas eu não, é liberado eu me sinto na Holanda aqui só não vende na banca.

[No entanto], eu acho isso um pouco ruim porque fica parecendo que são os moradores, que todo mundo que mora aqui é assim. Muita gente até, eu acredito, que vem ainda aqui fuma maconha na cozinha, cheira essas coisas, porque acha que todo mundo realmente usa e que é normal.

\section{O uso de drogas acontece porque a polícia não entra no campus}

Uma coisa eu sei, acontece muito [o uso de droga no CRUSP] porque a polícia não entra. Não adianta [o] segurança lá não vai ser bobo de falar aqui não pode, não tem como. O quê pode acontecer é tipo a polícia militar não entra na USP, então o pessoal tem mais facilidade pra fumar [porque] a polícia não vai aparecer.

Eu já conheci um povo, que eu sempre passo, a gente vê um povo da educação física [fumando]. Por ser livre facilita muito[para] os que usam.

\section{O acesso às drogas é muito fácil}

Eu acho que é uma questão bem complicada e é muito fácil o acesso, a qualquer hora e qualquer dia, mas propicia mais pra quem tem interesse também, porque tem muita gente aqui que não usa.

\section{Ainda sobre o consumo de drogas na moradia nota-se que há um conjunto de idéias de senso-comum como a pressão dos colegas para a experimentação ou a associação entre diversão e uso de drogas.}

\section{Os alunos que usam drogas pressionam os outros para experimentar}

[Tem] um povo mesmo, não sei se eles acham que é preciso estarem assim, que a gente tem que experimentar aquela onda hippie de todo mundo fazer isso [usar droga] também. 


\section{As pessoas só se divertem se fumam e bebem e isso incomoda}

Eu vejo pessoas que só conseguem se divertir porque fumaram, porque beberam e isso me incomoda bastante.

Há ainda visões contraditórias como a que o uso de drogas se dá nos apartamentos e em festas ao passo que a vida no CRUSP é conservadora e sem festas.

\section{O uso de drogas ocorre em festas e nos apartamentos}

Eu sei que existem festas nos fins de semana, nunca fui em uma festa, mas a minha visão é que deve ocorrer consumo de drogas em algumas das festas ou mesmo não sendo festa em alguns dos apartamentos também.

$\mathrm{Eu}$ acho [muito] complicado porque cada um quando está dentro do apartamento, entre aspas seu você é responsável por aquilo que você está fazendo, você não está em público, numa via pública, no corredor, no elevador tal você está dentro do seu apartamento dentro do seu quarto, tem como alguém chegar e bater na porta e falar olha, por exemplo, eu senti o cheiro e avisar o porteiro ou a guarda ou sei lá, fulano está fumando maconha aqui, [eles] vão rir. Provavelmente, [vão] falar deixa ele fumar.

Eu acho muito complicado porque é contraditório você vai estar mexendo tanto com o social mas é o individual é o subjetivo, é o direito da pessoa e ao mesmo tempo o dever então de verdade assim eu não sei.

\section{O estilo de vida no CRUSP não permite extravagâncias}

Em geral aqui as pessoas tem um estilo de vida assim bastante conservador, não existe muita extravagância. Se existissem essas extravagâncias, festas etc, talvez aconteceria uso de droga, mas onde não tem festa não rola, o pessoal fica na bebida no máximo.

Alguns alunos referem que não gostam nem do CRUSP nem de quem mora lá, um outro denuncia que a vida na universidade é complicada e que as oportunidades são menores para os alunos pobres, que constituem o universo 
dos moradores do CRUSP e há ainda aqueles que não se sentem seguros no CRUSP e na região em torno.

\section{Eu não gosto de morar no CRUSP e nem das pessoas que moram lá}

Eu não gosto de morar no CRUSP, eu não gosto das pessoas que moram no CRUSP, tirando o meu circulo de amizades assim os amigos são poucos, conhecidos bastante sim. O CRUSP é um lugar que não me agrada.

\section{A vida na universidade é muito complicada \\ É bastante complicada a vida na universidade.}

\section{Quem é pobre não poderá ser professor}

Você não pode ser professor porque você é pobre e se quiser tem que fazer a tal da iniciação científica.

\section{Não há segurança no CRUSP e nem na região em torno}

A nossa segurança é muito precária lá, não dentro do CRUSP só, mas fora, ali na região é uma tristeza, dá o maior medo de sair pra fazer alguma coisa. Agora é que tem uma padaria perto, que antes era tudo longe, não tinha, se a gente não conseguia jantar lá no CRUSP, o quê que vai comer, não tem onde comprar tem que sair.

Droga rola solto, o pessoal a gente vê que às vezes rouba as coisas, não tem como a gente falar, a gente sabe que tem um cidadão lá que é mais possível que tenha pego, mas não tem como provar, a gente não pode entrar e falar olha isso aqui é meu.

Então a gente fica meio inseguro lá, pelo menos o meu quarto está trancado. Eu só vou pra lá pra dormir, porque ficar lá eu não fico porque eu tenho receio. Eu saio de lá vou para faculdade fico, faço o que eu tenho que fazer, vou pra lá e durmo é isso que acontece

Aparece também um discurso que questiona a assistência dada às alunas que têm filhos durante o curso, como se significasse um estímulo à maternidade. 


\section{Auxílio às mães dado pela COSEAS pode estimular a gravidez}

Quando eu vou no COSEAS eu falo direto com a assistente social ou deixo alguma coisa por escrito, a respeito da maternidade. Eu acho muito legal você ter assistência para as mães, tipo você tem um filho vem estudar aqui, você tem uma casa, porque você tem um quarto pra criança separado, tem um quarto de casal, tem lavanderia tem tudo aí. Então acho mais do que justo o direito à creche, mas o quê acontece é que isso muitas vezes estimula, tem mães aqui que tem dois filhos, que teve filho aqui, engravidou aqui e ficou com o filho aqui. Eu acho que não é o caso. Eu acho que a gente tem que aprender a separar as coisas, a gente sabe o quê é anticoncepcional, o quê é camisinha e eu acho que o Estado não tem o dever de arcar com isso, assim, aconteceu um acidente tudo bem, mas eu acho que esse amparo demasiado acaba estimulando.

Então eu até falei com a assistente social, porque eles queriam parece mais duas maternidades, mais uma, não sei, e eu acho legal você investir na campanha de prevenção, porque [a gravidez] atrapalha a tua vida acadêmica eu acho isso. Aí então eu fui até falar com a minha assistente social sobre isso.

\subsection{A visão dos moradores sobre o consumo de drogas}

Nos discursos dos alunos sobre o consumo de drogas nota-se a presença das duas principais concepções que contemporaneamente têm alimentado a arena da prevenção ao consumo de drogas: guerra às drogas e redução de danos.

Conforme discutido no capítulo teórico, cada um desses campos é retroalimentado por um conjunto de teorias que vão desde a explicação para o consumo de drogas até um conjunto de estratégias para a prevenção. A análise foi então realizada, num primeiro momento, no sentido de compreender quais as teorias apresentadas pelos alunos para explicar o consumo de drogas.

$\mathrm{Na}$ concepção de guerra às drogas situourse a teoria explicativa que culpabiliza o indivíduo por sua condição e mudança. 
No que se refere às teorias explicativas que enfocam o indivíduo tem-se a proposição de que as pessoas usam drogas porque são frágeis para enfrentar um cotidiano de problemas, numa espécie de fuga e também uma explicação a partir de um conjunto desqualificador dos usuários de drogas, vistos como criaturas menos humanas.

\section{As pessoas usam drogas porque são frágeis para enfrentar um cotidiano problemático}

Bom, eu não faço uso porque acho que isso pra mim muitas vezes é uma fuga, tem pessoas que usam pra relaxar e tudo, mas eu acho que isso a gente usa porque está com problema, quer esquecer, está com a vida difícil, ah então vou usar pra dar uma relaxada, esquecer um pouco das coisas, pra mim muitas vezes isso é usado com uma fuga.

Na minha opinião a pessoa está passando por uma fase difícil da vida porque ninguém usa drogas assim, porque está totalmente estável emocionalmente. Eu acho que tem alguma coisa que está errada pra pessoa começar a fazer isso, pra querer uma reação tão violenta, assim no corpo e na mente, eu acho que desequilibra totalmente.

Eu já escutei cada papo, assim, tem gente que fala, os estudantes mesmo falam que a gente vive sobre intensa pressão então eles recorrem a isso [uso de drogas] e como tem muita gente que usa, muita gente vê, essas pessoas que vêem se sentem meio assim também vão procurar.

Além disso, o fato de ter entrado na USP não é a solução de todos os problemas, esses continuam, não alivia em nada na verdade, surgem novos em virtude de você ter entrado na USP. Isso eu acho também que de certa forma pode trazer um desânimo e pra canalizar esse desânimo, continuar tocando a vida, essa pessoa procura se refugiar num baseado.

\section{Os usuários de drogas são pessoas desqualificadas (criaturas menos humanas)}

As pessoas que usam drogas aqui no CRUSP são meio estranhas, são assim meio de barra pesada eu acho. Então fica mais difícil, tem outras pessoas que eu achava super legais e que começaram a usar drogas, aí pararam de estudar direito, usa maconha não estuda tanto, eram super inteligentes e aí fica só fazendo bagunça.

[Agora no geral, tem a questão] da fraqueza que vem, quero experimentar vai lá e experimenta e não consegue sair, nem sempre é culpa da pessoa tem alguns que a gente sabe que 
são retardados mesmo, que vai lá porque é legal e acha que é o topo da parada, mas tem gente que vai por pura inocência. Acho que depende muito, mas quem não tem muita personalidade lá [no CRUSP] acaba fugindo pro lado das drogas mesmo. Se todo mundo que morasse lá fosse contra as drogas, não fizesse o uso, e um que aparecesse lá a gente chutasse essa pessoa, eu acho que não ia ter essa coisa

Eu não quero ser assim, mas eu tenho um desprezo muito grande por usuário de drogas. Eu tenho desprezo porque eu não respeito as pessoas que usam drogas, até amigos meus, muitos eu parei de falar quando eu descobri que fumavam. É difícil conversar com a pessoa que usa droga, eu prefiro conversar com uma parede, porque a parede não fica retardada. Eu tenho uma opinião bem negativa sobre pessoas entende a linguagem da porrada, eu não sei se eles estão dispostos a conversar, eles não gostam de conversar, eles não gostam de dialogar.

[Bom, tem também] esse problema dessas pessoas que já usam o quê que acontece pra quem trafica vai preso [porque] é crime, [para] quem usa você pode oferecer ajuda, [mas] a pessoa tem que aceitar se ela não aceita tem um impasse qual é a solução desse impasse? eu acredito na força, eu acho que não há outra solução possível infelizmente.

No entanto, eu já tentei ajudar várias pessoas, mas foi tudo em vão, todas as pessoas que eu tentei ajudar querem me comprovar que isso não tem efeito nenhum na vida delas. Por exemplo, tem uma menina da minha sala que é usuária de maconha, cocaína e sei lá mais o quê. Eu já tentei convencer ela de várias maneiras, mas ela tenta me convencer totalmente ao contrário, então eu não consigo nem formular uma idéia sobre essas pessoas, eu acho que essas pessoas são tão imaturas ainda pra saberem as coisas direito, não quererem ver.

[Tem gente que fala] ah, a pessoa está passando por dificuldades e por isso procurou droga eu acho essa explicação totalmente banal. Eu passei por tantas dificuldades e nunca procurei. Porque que as pessoas vão [usar]? Porque querem mesmo, porque gostam.

Os estudantes universitários são percebidos como um grupo que usa

drogas por escolha, uma vez que têm informação, e que acredita estar imune aos problemas relacionados ao consumo de drogas.

\section{O universitário usa drogas por escolha}

As pessoas têm instrução, tem informação sobre isso [drogas], você pra entrar aqui na USP eu acredito que tenha lido jornais e revistas sobre isso. Então eu acho que é uma escolha. Por estar em uma faculdade tão boa como essa, eu 
acredito que a pessoa é madura o suficiente para saber o quê é bom e ruim, é realmente uma opção muito pessoal. Eles sabem muito bem o que está acontecendo o que eles podem fazer, o que eles não medem são as consequiências, então acho que não é questão de conscientização, porque eu acho que isso eles tem, acho que é um pouco de falta de vergonha na cara, todo mundo ter medo de ficar usando.

Se você está a fim de levar o seu curso com seriedade você vai levar, mas tem épocas que você descamba. Eu estou falando isso não é que eu sou assim ah! meu maior CDF essa daí, não cara, você apronta, tem época que você apronta pra caramba , mas tem época que você tem que dá uma segurada.

[Eu acho que] as pessoas são livres pra decidirem que tipo de drogas usam, eu tomo sorvete. As pessoas usam o que elas precisam, o que elas se satisfazem, o quê satisfaz a elas.

[Pra mim], a pessoa só precisa de ajuda realmente se ela buscar. [O uso de drogas] não me causa nenhum espanto, nenhum assombro, não me dá vontade de ajudar a pessoa esse tipo de coisa. Mas não acho que esse é o mesmo caso de um adolescente por exemplo, ou de um senhor alcoólatra, de um pai de família que se mete com bebida e tal.

\section{Os universitários não acham que poderão ter problemas advindos do uso de drogas}

No meio universitário mesmo, aqui, eu acho que são poucos os [usuários] que procuram ajuda, acho que são poucos. Isso porque eles acham que é de barato, que é porque curte, curte tudo. As pessoas geralmente não acham que isso seja um problema, que fumar maconha não traz prejuízo nenhum e tudo mais e no fim prejudica, eu vejo algumas pessoas se prejudicando muito com isso. Eu realmente acho que eles talvez não se toquem do quão grave isso é, porque o crack por exemplo é uma droga que se você fumar em duas vezes você fica dependente daquilo e você vai quere fumar uma terceira. É igual a questão da aids não vai acontecer comigo [ficar dependente]. Tem gente ainda que pensa assim.

\section{O usuário desperta sentimento de dó}

Então, às vezes eu fico com um pouco de pena de quem usa muito, de quem usa, começa de repente a fumar maconha e vai pra outros tipos de drogas, que acabam prejudicando muito a vida, incluindo a vida acadêmica. A pessoa tem muita capacidade e de repente vai por água abaixo, às vezes eu sinto um pouco de pena. 
Os alunos ainda contam que ver alguém usando cocaína é uma experiência marcante e que o uso pode estar relacionado a faixa etária e a uma fase de curiosidade.

\section{A primeira vivência com alguém utilizando cocaína no CRUSP foi aterrorizante}

Eu fui conhecer aqui uma vez numa festa de "república" aqui, eu nunca tinha visto ninguém cheirar cocaína e vi. Eu fiquei horrorizada, eu acho que é feio de ver a reação da pessoa, parece que a pessoa vai explodir, a pessoa fica com aquele olho. Eu não gosto.

\section{A questão da idade é determinante para o uso}

Eu converso muito com os amigos e eu acho que é pela idade mesmo [em] qualquer ambiente que você vê, nessa faixa de idade assim está tendo droga, mesmo fora da universidade. $\mathrm{Eu}$ lembro quando eu fazia cursinho sempre tem aquela turma, o pessoal da maconha.

\section{Existe uma fase de curiosidade}

E eu nunca usei porque na fase de curiosidade eu não tinha acesso e hoje não sei, não me chama a atenção, não me seduz

Há um discurso que ressalta a idéia de que não é natural a pessoa precisar de drogas para se divertir e há a idéia que as pessoas precisam ter mais consciência sobre suas vidas e que os culpados pelo uso de drogas não são nem o governo e nem as instituições.

\section{Não considera normal o uso de drogas para se obter diversão}

Eu não acho que seja legal você precisar de drogas, álcool qualquer coisa pra você se divertir, isso pra mim não é normal, pra você ficar alegre você precisa disso, não sei não aceito bem isso, acho esquisito. Pra mim é estranho já que não é natural, eu acho estranho você precisar de alguma coisa. 


\section{As pessoas precisam ter mais consciência sobre suas vidas}

Eu acho que as campanhas elas tem sido realmente bem pensadas, mas talvez falte alguma forma [para] chamar mais a atenção dos moradores do CRUSP pra isso. Até porque [o] uso de drogas não é uma coisa só no CRUSP, praticamente em todo o lugar [vem] se tornando comum, ficando cada vez mais próximo das pessoas todos os dias. Então são necessárias, não digo ações educativas, mas eu acho que falta às próprias pessoas uma consciência maior sobre suas vidas, sobre [suas] responsabilidades

\section{Os culpados pelo uso de drogas não são o governo e as instituições}

Eu acho que a gente vive num país que é subdesenvolvido sim, mas em países desenvolvidos o problema é o mesmo você tem um consumo de drogas altíssimo, uma população bastante culta, bastante educada. Então é por isso que eu digo não é só uma questão do governo é muito fácil você falar é do governo falar mal ou jogar a culpa na universidade é uma questão realmente de ser, que atinge cada pessoa, cada usuário, cada não usuário.

Nesse contexto, ainda é possível notar que o poder que a droga em si apresenta, é especialmente enfatizado no caso do álcool que contraditoriamente se apresenta como a "droga das drogas" ou como "nãodroga".

\section{As drogas alteram o comportamento}

Eu bebo cerveja, mas, eu acho o alcoolismo, você ser dependente de álcool uma coisa muito triste e meu pai era alcoólatra, então eu acho que é uma das drogas mais pesadas que existe, até de você observar mesmo no comportamento da pessoa.

Eu sou contra qualquer tipo de droga, [quer dizer], eu não sou contra a maconha e acho cocaína, crack qualquer tipo de droga lamentável, entendeu? Eu não gosto de conviver com pessoas que usam porque, realmente eu acredito que esse tipo de droga altera o comportamento, e sei lá. 


\section{O álcool não é uma droga}

Eu uso álcool sim, mas eu não acho que é uma droga.

Entre as estratégias para a prevenção, situadas no campo da guerra às drogas alguns alunos posicionaram-se incisivamente contra qualquer uso de drogas enquanto apresentaram um conjunto de sugestões sobre como lidar com os problemas relacionados ao consumo. O teor dessas sugestões é variado: necessidade de um policiamento ostensivo e uma maior coerção por parte da universidade; prevenção voltada para os dependentes de droga; e necessidade de identificar os usuários/dependentes (está presente a idéia de que eles incomodam).

\section{É contra o uso de drogas}

Eu bom, claro eu sou contra. Eu acho o uso da maconha muito ruim e eu acho que a gente por ser estudante e por estar numa universidade boa, ter um futuro, provavelmente será um bom profissional, usar drogas? eu acho uma coisa ruim assim, eu acho que usam a inteligência para uma coisa, mas em outras distorce totalmente, eu não aprovo o uso de maconha, de nenhum tipo de droga, nem cigarro na mão eu gosto, bebida alcoólica nada, mas infelizmente quase ninguém pensa assim.

Eu sou contra o uso e eu confesso que eu não me sinto bem em saber que pessoas usam e não me sentiria bem de saber que um amigo meu utiliza, eu acho que eu procuraria conversar com ele e tirar essa idéia da cabeça dele porque é algo muito complicado realmente. Eu acho assim extremamente negativo no sentido da saúde da pessoa é um caminho realmente complicado pra saúde dessas pessoas depois. É como dizem as expressões embarcar numa viagem meio que sem volta, algumas até conseguem ter uma recuperação, tentam voltar, se voltar pra vida, mas é uma questão complicada.

\section{O policiamento ostensivo deve criar ambiente de coerção}

Primeiro [deve ser feito] o que é feito na sociedade inteira, porque a USP por mais que queiram não está fora, ela não é uma entidade autônoma da sociedade, ela está dentro da sociedade. Pra diminuir [os problemas] só colocando o 
policiamento lá dentro [do CRUSP], só tirando o pessoal, fazendo uma inspeção rígida mesmo.

Um policiamento ostensivo no combate a tráfico de drogas tem que ter aqui dentro. Não contra o uso, o uso eu acho que aí é um problema mais sério, mas tem que ter um combate oficial de coerção violenta da polícia militar que é violência querendo ou não de uma forma ou de outra.

Então eu acho que no começo uma ação forte, de policiamento, [se] eu não posso fumar maconha na rua, não pode aqui dentro também. Então, eu acho que devia ter uma coerção maior de alguma entidade [como] da guarda universitária, não quer que entre a polícia aqui não entra, mas tem que cercear essas pessoas, como é ilegal o uso e o tráfico, acho que tem [que ter] uma resposta legal. O encarceramento, é uma resposta legal pra esse tipo de prática. Não sei se eles aceitariam uma ajuda de cunho humanista, eu acho que não. Eu conheci muita gente que é da pesada mesmo, eles não querem ajuda. Bom é isso. É só em uma ação que eu acredito

\section{Deve haver atividades direcionadas aos dependentes}

É, uma pessoa que quer sair desse modo de vida, se afastar um pouco das drogas [deve] ter uma atividade pra fazer. Eu já ouvi muitos falarem também que tem muito ataque de depressão assim quem está fora de casa, morando aqui. Talvez uma atividade direcionada pra essas pessoas evite um pouco as drogas, [algo que elas] pudessem procurar assim, é uma sugestão

Embora centrando a problemática do consumo de drogas na figura do dependente, num campo menos categórico, há aqueles alunos que recomendam estratégias mais próximas de uma abordagem de redução de danos, uma vez que reconhecem a especificidade de cada caso propondo que se pesquise a realidade do CRUSP. Consideram que a família ou os amigos devem mobilizar-se para ajudar; nesta categoria encontram-se também aqueles que denunciam e inexistência de política de tratamento para os dependentes e o casuísmo das práticas de prevenção tão característico da omissão do Estado com o problema das drogas. 


\section{É preciso identificar quem precisa de ajuda}

Eu acho que pesquisa é uma coisa legal porque talvez com pesquisa você possa identificar quem realmente precisa de ajuda e quem quer essa ajuda e identificar principalmente a quem essas pessoas estão incomodando. Eu acho que quando começa a passar do limite dela é porque aí ela está precisando mesmo de ajuda, pesquisa é uma coisa legal assim.

Talvez chamar os moradores, quando tem a reavaliação lá no COSEAS e a assistente social conversar com o morador se ele conhece alguém ou se no apartamento dele tem algum problema, esse tipo de coisa. Eu acho que uma abordagem assim é mais suave e indireta, do que você chegar diretamente na pessoa que usa, isso assusta e acaba parecendo coação assim, vem cá que nós vamos cuidar de você, eu não acho legal.

\section{A ajuda deve vir de alguém próximo}

Então eu acho que a melhor saída vai ser a da família [ou os] amigos, tipo você mora com mais duas pessoas no mínimo. Por isso eu acho legal ter uma convivência realmente com essas pessoas porque de repente ela pode perceber alguma coisa que você não tá percebendo, te dá um toque. Você vê seu amigo precisando vai [e] fala porque nós estamos longe da família e de repente você é um menino de 17 anos, vem pra cá pro CRUSP e começa a fumar maconha, depois está cheirando cocaína e está viciado naquilo. Tua mãe não sabe porque não te vê, teu pai não sabe porque não te vê, você não reconhece seu problema e de repente você põe sua vida a perder por causa de uma falta de consciência.

Aí acho que a ajuda teria que vir de alguém mais próximo, acho que é muito difícil uma campanha atingir esse tipo de pessoa que está muito certa do que quer, do que é e do que está fazendo. Eu acho isso.

\section{Não há política de tratamento para os dependentes: as práticas são casuísticas}

[O que acontece é que] você procura a COSEAS fala da pessoa e ela fala não a gente já ofereceu ajuda. Então elas por debaixo dos panos elas tem alguns atos de ajuda, sabe que a pessoa tem problema então oferece ajuda profissional mesmo assim, leva pra clínica, esse tipo de coisa, só que tem que ter a adesão, não é forçado esse tipo de tratamento

Eu sei de vários casos de pessoas que tem problemas com drogas que foram pra [uma] clínica de recuperação, a fundação da USP acho até que bancou isso tudo e que voltam 
pra cá muito bem, [mas] passa um certo período caem de novo. Eu não sei, eu não consigo pensar numa solução, eu vejo que as pessoas que querem ajuda de repente têm acesso a essa ajuda, mas que acabam caindo de novo. Eu não sei se elas perdem esse apoio de repente, se elas depois disso não tem mais um acompanhamento e acabam voltando até por isso, eu não conheço direito, não conheço tudo o que acontece.

Já no campo da redução de danos, elencourse os discursos pautados por teorias explicativas para o consumo de drogas menos reducionistas que aquelas que culpabilizam o usuário ou somente estão atentas aos efeitos das drogas. Assim, para os moradores do CRUSP, o consumo de drogas na moradia está relacionado aos processos de socialização, num mecanismo de perda de alguns laços de um lado e de esforços para reconstruí-los de outro.

Os estudantes falam então das perdas que sofrem quando chegam na moradia, pois se de um lado parecem ganhar uma certa autonomia e liberdade diante da perda da tutela próxima dos pais, sentem-se sem vínculo, sem saber como prosseguir. No processo de reconstrução da sociabilidade, consumir alguma droga - maconha notadamente - é apenas um detalhe. $O$ rateio para comprar comida, bebida, para sentir o conforto da proximidade e do carinho humanos constituem os mecanismos pelos quais a sociabilidade vai passando.

\section{O uso de drogas na moradia está relacionado aos processos de socialização (perda/reconstrução)}

Quando você vem pro CRUSP o que há na verdade é, ao mesmo tempo que [tem] essa coisa de uma espécie de libertação, da autonomia diante da autoridade dos pais há também um desvinculo da sua relação social, por exemplo, da relação com os pais, os amigos, com os familiares em geral, com a vizinhança coisa que faz sentido pro individuo deixa de existir onde você tem que reconstruir tudo aquilo.

$\mathrm{Na}$ verdade geralmente acontece um momento onde você reconstrói aquilo e não sabe se vai sua necessidade de afetividade de vínculo mesmo você não consegue construir uma sociabilidade aí você, sem achar, você vai pro uso da droga como uma forma tanto de suprir sua carência afetiva, como uma forma de você encontrar aquela sociabilidade.

Tanto é interessante você ver a forma como, como se dá a compra da droga, eu acho fenomenal. Tipo, na verdade é uma reunião, se ajunta dinheiro, vamos lá, parece uma festa 
assim sabe? Tanto é que no alojamento a gente fazia rateio pra comprar bebida, comida e aí os caras ficavam juntando dinheiro e $30 \%$ ia pra droga e os 70 outros ia pra [outras coisas] E na verdade era uma reunião, e todos iam lá pras pedras e tocavam violão e tomavam vinho e fumavam maconha a noite toda e tal, nós que não usávamos íamos lá e ficávamos lá porque na verdade era aquele o tipo [de] vínculo que o pessoal estava necessitando

Fumar maconha é meio que uma socialização e tem até uma história que eles não faziam churrasco se não tivesse maconha, não tem festa sem a ervinha. É até interessante porque chega um ponto que se você não tiver uma personalidade um pouco forte você perde um pouco da sociabilidade. Parece que a sociabilidade passa necessariamente pelo uso de drogas, o que é uma coisa interessante, não tem nem errado nem certo é no mínimo interessante como a sociabilidade se dá, tem que passar necessariamente pela droga.

[No que se refere] a universidade em si ela é muito, muito vazia em questões de relacionamentos questões de relacionamentos intersubjetivos, aqui no CRUSP [é assim]. A pessoa que usa drogas tende a aprofundar isso aqui, mesmo porque você é obrigado a estudar e se desligar às vezes parece que você fica meio esquecido aqui. $\mathrm{Eu}$ acho muito compartimentados os apartamentos é como se fosse uma cela pra cada um, uma cela individual aí quem já vem pra cá com o vício das drogas tem isso como incentivo pra continuar usando ou usar mais, agora quem não usa, não sei se tende a usar por causa disso.

Para outro grupo, na mesma direção, o consumo de drogas é a busca de alguma resposta...

\section{O uso de drogas é a busca de uma resposta}

Do LSD a maconha ao comprimido todo mundo está procurando resposta, eu procuro a minha resposta, insisto, no sorvete. Eu tomo sorvete.

Assim, o efeito do produto é minimizado.

\section{As pessoas não mudam seu comportamento}

\section{porque usam drogas}

$\mathrm{Eu}$ acho que as pessoas que consomem as drogas têm o comportamento de sempre, não mudam porque consomem droga ou não. 
Buscando ainda uma compreensão mais abrangente, o contexto também determinará a condenação ou não do usuário.

\section{O usuário é bandido ou herói dependendo do contexto}

No começo era muito complicado pra mim porque eu vim de uma cidade muito pequena que as pessoas que usam drogas são marginalizadas mesmo, que é bandido é quem não presta. Eu antes de eu vir pra cá eu fui pra outra universidade e lá era a mesma coisa, embora fosse uma cidade muito maior que a minha. A minha cidade só tem 6.500 habitantes e lá [nessa outra cidade] era a mesma coisa, a gente tinha alguns colegas que fumavam maconha, mas era escondido porque é feio, é errado e tudo mais.

Quando eu cheguei aqui foi complicado porque foi uma inversão de valores por completo, porque os marginalizados eram quem não usava, quem nunca tinha usado.

Há também um conjunto de explicações de natureza multifatorial de senso-comum que não constrói uma explicação hierárquica sobre o consumo de drogas, mas reúne de maneira desordenada tanto a idade, como a condição de aproveitar a liberdade que se desfruta na moradia, como o fato de encontrarse desgostoso com a alguma coisa, a necessidade de ser aceita num grupo, que envolve aspectos psicológicos e políticos e assim por diante.

\section{O uso de drogas é multifatorial}

Existem diversos motivos que podem levar uma pessoa a usar droga, a vontade de experimentar, principalmente quando você é muito novo aqui no CRUSP as pessoas entram numa média de idade entre 18 a 22 anos, e essa é uma idade em que você quer viver coisas novas assim eu acho que faz parte do espírito humano essa sensação de aproveitar. É a influência, a condição de vida que talvez leve. Porque a pessoa no começo [aqui no CRUSP] realmente não sabe muito o quê fazer, é tudo de repente. Ë tudo de uma vez, é tudo novo, o lugar é a comida da mãe que vai deixar de comer e que faz muita falta emocionalmente, é o lugar que você vai dormir, pessoas novas que você vai conviver de uma hora para outra, você vai criar uma pseudo-família [com quem vai conviver] durante um tempo. Na faculdade as relações que você vai ter com pessoas que são legais e com pessoas que não são legais, tudo isso é 
muita coisa pra pessoa assimilar. Então acontece da pessoa ficar meio perdida e de repente buscar isso [usar droga].

[Pode ser também] uma pessoa desgostosa com a vida, pode estar usando por deboche, nos anos setenta tinha muito disso, ou porque é legal e a galera usa. Tem pessoas que chegam e caem nisso por inocência até, por essa coisa de estar sozinho, longe da família, saindo de casa muito jovem acabam começando a se prejudicar, eu acho isso bem complicado.

Eu tendo a crer que a pessoa usa em muitos casos pra ser aceita no grupo meu colega fuma porque eu não vou fumar? Uma outra coisa também é que em alguns cursos há uma carga de exigência muito grande então as pessoas acabam ficando estressadas, então elas querem ter algum tipo de válvula de escape e algumas acabam se voltando pro o uso de drogas.

[Esse] é na verdade é um problema enorme porque você envolve aspectos psicológicos, você envolve aspectos políticos, então a questão é bem mais ampla do que a gente pensa. Se a gente for pegar a educação do indivíduo, as condições sociais e econômicas nas quais ele vive é o problema que atinge proporções muito maiores do que a gente imagina.

\section{Nessa abordagem multifatorial, desta vez tentando sair do senso- comum, adota-se uma linguagem ainda muito frágil para explicar o consumo de drogas, mas que denota preocupação em buscar elementos das disciplinas científicas.}

\section{Discurso cientificista}

É uma questão [sobre a qual] eu não consegui ainda definir uma opinião minha. Falam [que] é uma doença, não é qualquer um que vai se viciar, mas ao mesmo tempo [eu] acho que se você pensar isso como doença, a gente tem que ter o cuidado pra não reduzir a pessoa à doença. Existem vários outros fatores que vão influenciar e interferir em ela usar ou não. Tem os acho que os [fatores] orgânicos os fisiológicos sim, mas também acho que tem questões de personalidade, como foi criado, desde pequeno, não sei, se é mais influenciável ou não, acho que são várias coisas.

[Tem também o fato de] estar em busca de alguma coisa, tem algum tipo de pendência ou emocional ou enfim física ou química mesmo não sei e aí busca na droga e fica ligada, fica física química ou psíquica também. 


\section{O uso faz mal a saúde}

[Eu acho que as pessoas] deveriam parar de usar porque faz mal a saúde

É possível caracterizar uma série de sugestões dos alunos sobre como proceder frente ao consumo de drogas dentro da concepção de redução de danos: as atividades preventivas devem ser regulares, diversificadas e com linguagem adequada ao público; deve ser oferecido mais do que informação sobre o tema e se faz necessário conhecer a realidade dos usuários, procurando se aproximar deles. Além disso, há referência à idéia de que não se deve abordar somente os aspectos negativos relacionados ao consumo de drogas e sugere-se ainda a utilização de estratégias interativas na realização de atividades de prevenção.

Assim, a descontinuidade das atividades junta-se ao casuísmo já denunciado pelos estudantes em outro momento. A proposta é de uma linguagem comum ao jovem que possa atingi-lo, como a utilização de filmes e outras atividades culturais.

\section{A prevenção deve ter atividades regulares e diversificadas de acordo com o público a que se destina}

Atividades [devem ser] contínuas, não isoladas, por exemplo, em dezembro, na metade do ano, em março, uma atividade, aí a próxima daqui a três anos, essa descontinuidade no meu entender tem pouca eficácia, eu acredito em projeto, em ações contínuas, duradouras, porque eu acho [que] essa questão é uma questão que não vai se esgotar em um projeto apenas, uso de drogas, não vai desaparecer daí a necessidade de ter uma ações regulares [e] diversificadas. Diversificadas no sentido de falar a mesma língua da pessoa que você quer trabalhar, com teatro, comédias eu acho que ajuda você ironizar, por exemplo, umas certas atitudes eu acho interessante tirar toda todo aquele peso que a sociedade de certa forma passa pro usuário de drogas. Eu acho que é legal, atividades então o teatro, filmes, reuniões palestras frequientes, eu acho que isso ajuda, materiais, linguagem acessível para os moradores, matérias do tipo HQ [história em quadrinhos] podem ajudar, formato de HQ. Acho que ajuda, uma 
linguagem mais próxima, murais, acho que ajuda, mas freqüente, tudo isso coligado não isolados, pode fazer isso todo o mês, usar o mural, o teatro, usar o CINUSP. Filmes com o tema, teatro, palestras sobre o tema, pode usar até o próprio Anfiteatro Camargo Guarnieri e discutir o tema, panfletos.

É verdade, então eu acho que [os moradores] participariam, isso a longo prazo, eu acho que pra já, num primeiro momento não,[mas] com continuidade, com ações regulares[sim]. Eu acho que dessa forma ajudaria bastante a tratar da questão drogas no CRUSP, [não] só no CRUSP, mas nas escolas [também]. Eu acho que ajudaria bastante essas atividades diversificadas, com várias linguagens. Eu acho que isso ajudaria muito a atingir o usuário de drogas, sinceridade eu acho que pensando em alternativas eu acho que contribuiria bastante. Não fazer sempre da mesma forma sempre com a palestra

Daí a necessidade de criar ações com linguajares, com leituras diferentes, com abordagens diferenciadas pra atingir o usuário de drogas, eu acho que dessa forma envolveria sim

\section{A idéia de depositar informações não agrada aos estudantes. Partindo-se de informações verdadeiras sobre drogas, deve-se cuidar do espaço para interpretação dessas informações.}

\section{Para fazer prevenção é preciso mais que informação}

Eu acho que já tem grupos pra esse tipo de discussão, eu não sei como são feitas essas discussões lá dentro, [mas sei que] não adianta você chegar e jogar um monte de informações pra uma pessoa porque isso não adianta de nada, a pessoa está gostando [e] você falar também que droga é ruim, até que ponto é ruim? A pessoa está experimentando, está gostando, está legal como é que você fala que isso é ruim, você que nunca provou, você que não sabe o quê é, chega aqui e fala assim.

O caso aqui não é falta de informação, a menos que eu esteja enganada supondo que as pessoas são mais inteligentes do que elas realmente são, mas eu acredito que aqui o caso não é falta de informação. Eu acho até legal o esforço do COSEAS em distribuir panfletos dizendo que é prejudicial, que mata não sei quantos neurônios, que acontece isso, aquilo outro, mas eu acho que não é o caso, acho que não é falta de informação. Quem estuda aqui já sabe as consequiências do uso de drogas então você ficar batendo na mesma tecla e eles rejeitando a mesma tecla o tempo todo, então é um confronto que não vai levar a um lugar. A maneira como as pessoas interpretam, 
recebem e interpretam essas informações isso é um desafio maior E eu acho que aí que reside a grande questão hoje não só pra COSEAS, mas pros governos, pras autoridades de saúde trabalharem isso junto a população.

A prevenção deve primar-se então por conhecer a realidade do consumo de drogas, seguir uma filosofia práxica, ou seja, cuja reflexão seja feita a partir da experiência com drogas.

\section{Para fazer prevenção é preciso conhecer a realidade dos usuários e procurar se aproximar deles}

$\mathrm{Eu}$ acho assim, tudo que for trabalhado, mesmo com o pessoal lá, em qualquer lugar assim de drogas, você tem que partir do pressuposto do quê que a pessoa acha sobre a droga, o conceito que ela tem e você trabalhar em cima do que ela tem como conceito pra ela. Não chegar lá [e] quem chega lá geralmente não usa e aí e fala besteira e a pessoa acaba desencorajada a continuar no grupo. Eu acho legal um grupo que pega a experiência do outro e trabalha em cima da experiência do outro e não ver só um lado das drogas, está fumando não sei quanto por dia tá cheirando não sei quanto por dia, porque que essa pessoa está fazendo isso, tem muitas outras coisas por traz tem que ser um grupo de amigos mesmo, de contar experiências.

Infelizmente a maneira que é abordada o tema que são dadas as palestras do tema droga e a postura passada, e isso a comunicação verbal tem muito a dizer a respeito não permite uma aproximação entre o usuário e o especialista do tema drogas.

Com abordagens diferenciadas, com acessibilidade, a pessoa que tiver que tratar o tema tem que se mostrar acessível, não adianta você falar, se mostrar todo aberto sobre o tema, compreensível [e] tudo mais se a sua postura não demonstra isso. Eu acho que geralmente quando se trata desse tema drogas, geralmente eu acho que o usuário acaba vendo isso a comunicação não verbal que é passado quando é tratado do tema. 
Você fazendo uma palestra abordando o tema drogas sempre da mesma forma a pedagogia oculta que é passada é essa você está errado, toma cuidado, você vai se ferrar. Em vez de aproximar mais o usuário pra participação dele. Quando você não vê uma acessibilidade, uma pessoa que você pode consultar, conversar a respeito, acho que fica difícil você ter a aproximação, o envolvimento do usuário. Se não for feito dessa forma eu acho que fica difícil ter resultados.

Assim,

\section{Falar só sobre os aspectos negativos não resolve}

Simplesmente falar dos males, dos malefícios da droga, acho que não resolve.

\section{Sugere-se então que os programas sejam dinâmicos que possam} assumir algum significado emocional para as pessoas.

\section{A prevenção precisa de estratégias interativas}

É muito complicado porque você está usando o negócio [droga] e acha muito bom agora de repente você não sabe quando tem um limite, o limite que a coisa começa a te dominar e aí que é complicado e é aí que você precisa, sei lá [de] alguma coisa pra te abrir o olho, mas eu não sei ainda o quê. Eu posso ter alguma noção em relação ao alcoolismo, alguma noção muito vaga. Eu acho que o caminho é meio parecido, mas vai um pouco meio de dentro primeiro, precisa fazer alguma coisa pra pegar de dentro. Uma coisa o visual eu não sei se rola, como eu já vi alguns cartazinhos, alguma coisa sobre consumo de álcool, legal você olha o desenhinho, legal não é comigo.

Eu peguei até um texto legal uma vez dizendo assim o que significava quando você começava a ser dependente ou não, algumas coisas indicando, algumas perguntas se você respondia um certo número aquilo significava que você era dependente, ou não isso eu acho que é uma coisa mais ou menos valida, que sinceramente cara você olha o papel você começa a ver, você começa a se questionar. Isso aí eu acho que é alguma coisa que tem alguma coisa de concreto sendo feito pra mexer com esse interior. Mas eu acho que aquilo é um pouco de coisa válida. Você jogar tipo, questionar algumas coisas, algumas coisas básicas em relação pra pessoa tentar se avaliar e a partir daí buscar alguma coisa, isso daí eu acho que é uma coisa pode surtir algum efeito. 
Coerentemente ao conjunto de explicações mais amplas que os estudantes elaboraram e às estratégias por ele propostas para a prevenção, são elaborados também discursos sobre a necessidade de superar o preconceito relacionado ao usuário bem como uma atitude mais tolerante que envolve a não punição dos usuários.

\section{É preciso superar o preconceito relacionado ao usuário}

.Eu acho que isso ajudaria bastante a tratar do tema e tirar esse peso e tudo isso com o intuito de tirar esse peso, de que o usuário é um marginal, um desequilibrado, eu acho com isso até possibilitaria com que essas pessoas sentissem confiança em procurar mais informações

\section{Não se deve punir os usuários}

Então [a minha sugestão é] fazer alguma coisa mais no sentido da prevenção eu acho [melhor] do que punição. Você não vai expulsar ninguém nem condenar porque usa drogas isso é ridículo, [pois] punição eu acho que não vai ter resultado nenhum [porque] essas pessoas sempre ficam procurando motivos pra se revoltar, acho que pode causar mais danos ainda pro CRUSP, não da pra controlar essas pessoas.

Claro, se for um caso extremo como já aconteceu que eu acompanhei de longe, que os moradores foram expulsos, acho que foram encaminhados para tratamento clínico, mas assim foi bem extremo, agora fora isso acho que não é tanto na punição é mais na prevenção mesmo, dar um acolhimento pra essas pessoas, não sei, [talvez um] serviço de psicologia, não sei acho que é mais prevenção assim que eu penso do que atuação.

Nesse contexto, uma sugestão interessante é a realização de um debate social amplo sobre o tema, denunciando os lucros do narcotráfico e buscando saídas.

\section{Deve haver um debate social amplo sobre drogas}

Eu acho precisa existir um debate maior a respeito das individualidades, de como as pessoas percebem o uso de drogas realmente, como isso afeta a vida delas, o consumo seja em 
suas famílias seja a própria pessoa é aí que o trabalho deve ser começado para que o uso se reduza, para que o narcotráfico se enfraqueça, que na verdade se tornou um negócio altamente lucrativo hoje em dia. Infelizmente [é] trágico demais e mais eu acredito que exista uma saída sim, eu acho que nem tudo é a morte, nem tudo é o caixão. É assim que eu vejo essa questão.

Os alunos apresentam sugestões e comentários específicos sobre a prevenção ao consumo de drogas no CRUSP. Eles sugerem que sejam desenvolvidas atividades com os alunos ingressantes (os bixos do CRUSP), uma análise inicial e/ou acompanhamento psicológico, uma pesquisa para que se conheça melhor os moradores e ressaltam ainda a importância da promoção da integração entre os alunos como forma de enfrentamento da solidão e desenvolvimento de sociabilidade.

\section{A prevenção deve se iniciar com a recepção aos calouros, criando clima de sociabilidade}

[Eu] acho que[as atividades] podem ser feitas pra quem chega, bixo mesmo, não pra quem já ta aqui a um ano. Mas pra quem chega como bixo é uma orientação, mas não assim não tome drogas, droga é um monstro, é mostrar o quanto pode ser prejudicial no início de um curso da pessoa, ela se envolver com drogas e não saber o que está fazendo, nesse sentido acho que é legal ter uma orientação porque muita gente começa de uma maneira e não sabe o que fazer e perde ano, perde semestre, nesse sentido. Mas não [falar] a droga é um monstro, mas mostrar o quanto a pessoa pode se prejudicar, não criando assim um inimigo, um grande inimigo, porque é o grande inimigo que desperta a curiosidade, nesse sentido. Não pode ser visto como um grande inimigo, mas como uma coisa que pode prejudicar quem não tem muito discernimento, está chegando agora, então chega primeiro, se ambienta e o resto é conseqüência do que você pretende

[Portanto] eu acho que uma das coisas era criar, atividades que acolhessem os calouros e criar um ambiente de convívio mais intenso. O pessoal chega aqui na USP com muita vontade de querer saber sobre várias coisas, sobre questões, atividades culturais, se abrir um concurso de literatura a maioria vai entrar. Tipo, de forma que o discurso antidrogas não apareça de forma moralista como fazem os pais dos outros alunos, o COSEAS não pode trazer, por exemplo, falando do CRUSP, o COSEAS não pode trazer pro CRUSP um discurso paternalista contra droga. Eu acho que é muito 
mais além, porque na verdade você não ta falando com pessoas que [tem] o mínimo de instrução.

Atividades [podem ser] culturais e principalmente com calouros. Tipo de tentar criar um ambiente, um estilo de sociabilidade que não necessite, que não precise necessariamente passar pela droga. [Para que] você não necessite fazer [ou] elaborar uma rede social que passe pela droga.

\section{A USP precisa conhecer o morador do CRUSP}

Então tem que saber qual é o estilo, sei lá, o perfil psicológico dessas pessoas que entram aqui, porque a gente faz análise sócio-econômica e acadêmica anualmente, mas psicológica não então muita gente que entra aqui entra com problemas e às vezes se aprofunda nas drogas porque aqui você não encontra muita saída pra problemas assim pessoais.

[Poderia ser] feita [essa análise], não [como] uma condição pra que a pessoa ingressasse no CRUSP, mas como um índice pra se ter uma idéia de quais são as necessidades dos moradores aqui, quem são essas pessoas, quais são as possíveis carências [que] elas podem ter e que o CRUSP não supre e a universidade não supre.

A gente que trabalha, no mercado de trabalho [sabe que] o sindicato está gastando todo o dinheiro que tem pra falar o quê é que está acontecendo no mercado de trabalho, o quê que é isso aí, que empresa é aquela, [em] quê que o cara está investindo. Então é a mesma coisa aqui enquanto não souber quem chega, quem sai, como que chega, como que fica, como se dá daqui a três anos, quantos usam, quantos não usam eu acho que é um pouco caótico ainda. Acho que a instituição que seria responsável por um tipo de política está bem longe na verdade de fazer, de ter condições de fazer algo efetivo.

Isso, na verdade, fica em aberto se você tiver aqui uma instituição que trabalhe com os alunos do CRUSP e que tente entender o que se passa quando você vem pro CRUSP tanto como você mesmo identificou não há nenhuma pesquisa sobre os alunos do CRUSP não dá pra fazer política sem pesquisa.

\section{Deveria ter um acompanhamento psicológico para os alunos}

Eu achava que já tinha, já tem um acompanhamento

psicológico? Um acompanhamento, continuar esse acompanhamento, que eu acho que tem, não sei. 


\section{Desenvolver programas que promovam a integração entre os moradores e diminuam a solidão}

Pensando que a causa ou um dos motivos seria as pessoas se sentirem sozinhas, se sentirem fora de um ambiente familiar, não sei talvez se tivesse mais programas de integração social entre os moradores, mais atividades, tornar um lugar mais familiar, mais um ambiente de família mesmo, de casa as pessoas se sentirem assim menos sozinhas talvez isso, talvez eu não sei, uma idéia só.

Há também uma sugestão para que a universidade disponibilize o acesso a tratamento e suporte para alunos dependentes que desejam ajuda. Além disso, sugerem também a oportunidade de que os alunos possam fazer um estágio que possibilite ampliar a visão relacionada aos problemas advindos do uso de drogas e falam da necessidade de monitoramento da entrada de pessoas nos prédios do CRUSP.

\section{Deveria haver tratamento para os alunos dependentes de drogas no $\mathrm{HU}$}

[Deve-se] disponibilizar um programa de tratamento, sei lá pelo $\mathrm{HU}$, eu ouvi falar dum programa porque a moça daqui ela trabalha no CEPE e tem um horário lá que é de funcionários do $\mathrm{HU}$ que tiveram proble mas, com drogas, que o HU disponibiliza isso, sei lá podia ter uma coisa assim ter uma linha [telefônica] pra pessoa poder procurar, a quem interessar.

\section{Um estágio na USP muda a visão sobre os usuários de drogas}

[O uso de drogas] não me incomoda não. Bom, é complicado tocar nesse tema se incomoda ou não, já me incomodou, antes me incomodava bastante porque eu tinha uma visão muito preconceituosa do tema. Eu via o usuário de drogas como um marginal, eu não conseguia desassociar um usuário de não ser um marginal, um usuário de um traficante, eu tinha dificuldade de fazer essa dissociação. Depois de um estágio intenso e do contato com a perspectiva de redução de danos, que é a perspectiva européia, não a guerra contra as drogas, e a proposta que esse novo olhar propõe, que é entender o usuário, não discriminá-lo [mudei minha visão]. 
Procurar conscientizá-lo do uso, claro com o objetivo de leválo a ponto de não querer usar mais, eu até cheguei a comentar, me deixou mais a vontade em manter contato com usuários de drogas. Porque assim não tem a preocupação de discriminá-lo, mas sim é mais fácil, quando você passa a procurar entender o porquê dele estar usando, dele ter esse vício, se de fato é vício, nem todos os casos são, fica mais fácil o relacionamento a aproximação. Você não vê o outro como inimigo, nem ele te vê como inimigo. A aproximação fica mais fácil, acho que possibilita muitas coisas, maiores trocas. A partir desse estágio, [que] me ajudou bastante nesse sentido, passou a ser indiferente uma pessoa que usa com uma que não usa, tanto também como uma pessoa que fuma cigarro como uma que fuma maconha, pra mim essa diferença passou a ser insignificante, uma pessoa que usa, uma pessoa que não usa e pronto. Pra mim não tem nenhuma diferença não, hoje não me incomoda mais.

\section{Faz-se necessário monitorar a entrada de pessoas no CRUSP}

Eu acho que tinha que ser feito uma fiscalização maior nas entradas, na portaria, até porque junto com essas pessoas que vem só pra dar um peguinha e sair vem gente que rouba bicicleta, vem gente mexer na nossa comida que está na cozinha. Diminuiu bastante, melhorou bastante, dizem que antigamente a cinco, seis anos atrás era muito pior, agora está bem melhor, [mas] ainda existe um pouco.

Quando eu estava no primeiro andar eu le mbro de gente que morava aqui sem ter vínculo nenhum com a universidade e essas pessoas diziam que traziam drogas pra cá, vinham da favela no geral. Podiam controlar mais isso com segurança, um pouquinho mais de rigidez na entrada desses moradores ou quem vem de vez em quando eu acho que os porteiros sabem quem não tem vínculo nenhum e está sempre vindo, podia controlar um pouco isso. Até que não vai evitar de trazerem droga, mas alguma violência que possa ocorrer, alguma coisa que possa acontecer de mal aqui pode ser culpa deles.

Uma boa parte dos alunos refere conhecer o trabalho preventivo desenvolvido pela COSEAS no CRUSP, no entanto há críticas sobre a forma ingênua como esse trabalho é desenvolvido e sua falta de credibilidade junto aos alunos. A sugestão é que se invista em divulgar a realidade da moradia a partir do ponto de vista daqueles que necessitam da moradia para concretizar seus estudos. 


\section{Conhecem o programa de prevenção desenvolvido pela COSEAS}

Aqui no CRUSP, por exemplo, tem muita campanha, o COSEAS todo mês lança campanha "Boca do CRUSP" de prevenção as drogas. [O] na Boca do CRUSP sempre está soltando uns panfletos, tem camisinha [e] também um monte de coisa. Eu acho uma boa iniciativa pelo menos pra orientar as pessoas e dar a elas o poder de escolher, ela sabe das conseqüências então ela opta se ela quer ou não.

É [também] louvável a atitude deles de procurarem alternativas a isso, mesmo oferecendo esses programas, esses culturais e sociais que dêem uma integração e diminuam essa sensação de individualidade que as pessoas têm.

\section{O trabalho de prevenção da COSEAS não atinge os moradores}

Essas atitudes da COSEAS que são tentativas de minimizar o uso, de incentivo das pessoas terem outras atividades, mas ao mesmo tempo isso é complicado por conta da visão de mundo dos moradores que tem atitudes de ressalva em relação a administração. Muito embora eles sejam totalmente beneficiados pela universidade ou por não concordarem com o método de administração ou porque eles querem ter mais benefícios, não convém agora dizer porque que eles são contra ou o quê. Então as campanhas perdem um pouco da força na medida em que as pessoas realmente não levam a sério.

[Mas mesmo assim] eu acho que não tem muito o quê fazer, além do que o COSEAS tem feito porque eles fazem campanhas, assim todo o ano eles fazem e tem até o dia de prevenção que eles vem põe a mesinha aqui em baixo, as assistentes sociais recebem o pessoal, conversam, tal. Eu acho que o problema está que não vai atingir o público que o pessoal que realmente precisa porque se eles não reconhecerem que tem o problema não vão procurar ajuda.

[Só que eu] vejo [que o] trabalho da COSEAS não funciona [decido] a forma como é feito não adianta é muito, como eu posso dizer, acho às vezes que o tratamento que eles dão é até infantil. Eles vão chamar a atenção exatamente de quem não usa, eles fazem os painéis com o Chico Bento desenhado se bem que eu não sei se foi do grupo da COSEAS que fez o painel uma vez num dos blocos só. Mas eles usam umas coisinhas que é exatamente aquilo que quem usa droga mais critica. Eles [os usuários] dão risada ah!ah! então não vejo que seja de uma forma boa não. 
Essas campanhas não têm sido eficientes na medida em que o consumo continua o mesmo, quer dizer você continua tendo as mesmas pessoas utilizando e além do mais grande parte dos moradores do CRUSP mantém uma atitude de descrédito em relação a COSEAS, então isso prejudica muito o trabalho deles de combate nesse sentido.

\section{Deve-se divulgar uma visão de mundo de quem tem interesse no aperfeiçoamento na moradia}

Eu penso que deveria ter uma mobilização do pessoal que organiza,: do COSEAS, da reitoria, da prefeitura, não sei que órgão que deveria fazer isso, mas deveria ter tipo uma publicidade mesmo, uma propaganda do que é o CRUSP, como funciona. [Deveria] existir uma espécie de trabalho da COSEAS meio que tentando monitorar essas coisas talvez assim um trabalho de comunicação realizado junto aos veículos, não digo censura é claro que isso não pode acontecer, mas assim é preciso também que se valorize os aspectos positivos aqui dentro da universidade. O CRUSP pode sim ser considerado [e] ter uma boa imagem.

Ainda nesse vertente e reproduzindo as críticas feitas ao proibicionismo e à guerra às drogas por diferentes setores de nossa formação social, os alunos não acreditam em campanhas preventivas do uso indevido de droga e consideram que os especialistas desconhecem a realidade dos usuários, fazendo generalizações infundadas.

\section{As campanhas de prevenção de drogas não funcionam}

O que eu acho que poderia ser feito, meu eu não sei se uma campanha resolveria, entendeu, porque até hoje eu nunca vi uma campanha que funcionasse. Então eu acho assim, deveria ter alguma coisa, mas eu não sei o quê, alguma coisa diferente do que existe ms campanhas contra drogas pra se toca eles [os usuários].

A assistentes costumam fazer uma reunião, tentar trazer as pessoas para que as pessoas falem, até fizeram uma vez a reunião em grupo assim. Eu acho que é uma coisa chata, mas ao mesmo tempo eu acho que é uma coisa que pode funcionar. Fazer com que as pessoas venham e comecem a falar as coisas porque eu não sei se você colocar alguns cartazes ou fazer alguns vídeos algumas coisas e achar que você ta fazendo uma campanha isso vai sensibilizar as pessoas. Eu acho, tinha que ter alguma coisa pra mexer um pouco não [com] o lado visual, 
assim, mexer com o interior das pessoas, porque droga mexe com o interior.

Eu acho que quem é dependente de droga precisaria primeiro ter consciência disso, do mal que se tem, do mal que faz pra ele mesmo e segundo precisa de alguma coisa pra falar, pra tentar expor. Eu acho que funcionaria um tipo de terapia em grupo, alguma coisa nesse sentido, eu sei que é muito difícil.

\section{Os especialistas desconhecem a realidade do usuário}

Por mais que não queira, você acaba indo com um certo preconceito dependendo de quem vai dar a palestra. [O palestrante tem] um olhar diferente, um olhar de quem nunca viu, mesmo que nunca tenha fumado de que nunca viu, de que nunca conviveu com uma pessoa que use drogas e que é normal como a gente. Todo mundo taxa e acha que é louco, não é assim uma grande parte não é assim. Todo mundo pega só a exceção eu acho que esse é um grande problema em relação as drogas.

Muita gente vai pras drogas em relação a tudo que eu falei pra você no CRUSP, que acontece todo mundo pega o que é notícia, assim o que é [manchete] e é isso em todo o lugar.

Outro ponto levantado por alunos é que a melhor alternativa ao proibicionismo seria a liberalização do consumo de drogas, pois assim os limites estariam mais claros. Nessa perspectiva é importante a diferenciação feita entre usuário e traficante. Há também uma sugestão de que para trabalhar com o dependente faz-se necessário compreender sua motivação para o consumo de drogas.

\section{Contra o uso, mas a favor da liberalização das drogas}

Talvez eu fosse até a favor de alguma liberalização das drogas mesmo sendo contra, não gostando, mas eu acho que as coisas ficariam mais claras. Só que assim aqui é proibido, o pessoal hoje no Brasil esqueceu, mas hoje ainda é proibido no Brasil usar droga, usar não, porque é meio complicada a expressão do usuário e do traficante. 


\section{Não condena o usuário, mas condena o traficante}

Não sei assim, eu acho que é um direito que a pessoa tem [usar drogas]. Eu sou contra quem vende drogas, quem usa não, apesar dele estar perdido na vida do traficante. Eu não uso, mas não condeno quem usa acho aceitável, sei lá não sou contra, mas sou contra quem discrimina, quem condena o usuário, o traficante não.

É pra mim tem sim o traficante que é perverso. Agora como eliminar o traficante protegendo o usuário, é uma solução que eu não sei como, difícil, mas sei lá, acho que não cabe punir o usuário como se ele fosse traficante, então eu acho isso.

\section{Para abordar o usuário deve-se entender o motivo do uso}

Eu acho que o que pode ser feito é realmente procurar trabalhar com a pessoa porque que ela está fazendo aquilo, será que é só pra relaxar mesmo? Até onde está o problema que a pessoa passa pra ela usar?

Do lado mais tolerante então há uma parte considerável dos alunos que reconhece o consumo de drogas no CRUSP, sem que isso thes cause problemas. Os problemas com o consumo são relativizados na admissão de que há diferentes tipos de usuários e que nem todos têm problemas com o uso de drogas, necessitando de tratamento, por exemplo, e que a porcentagem de quem precisa de algum tipo de ajuda devido a problemas decorrentes do consumo de drogas é pequena.

Há uso de drogas no CRUSP, mas isso não causa problemas

O pessoal é gente boa, eles não quebram nada, só fumam maconha, acho que só, e nos outros prédios também em geral aqui no CRUSP é assim. As pessoas usam sim, principalmente maconha, mas não criam problema nenhum, cada um na sua, nunca deu problema nenhum em relação a isso, cada um usa individualmente lá no seu apartamento nunca deu problema nenhum, pelo menos ali onde eu moro.[O] tráfico, esse tipo de coisa nunca teve e o pessoal usa numa boa, não incomoda 
ninguém.Não sei assim, dizem que existe até traficante, mas eu não conheço se tiver é discreto não incomoda a vizinhança.

No meu andar tem gente que usa e usa bastante, quase todos os dias assim, mas não incomoda ninguém em nada Vamos dizer assim conheço pessoas que dizem que usam drogas, mas eu nunca vi, eu nunca experimentei nada, eu não posso dizer.

Muita gente fala porque às vezes vê alguém usando alguma coisa, mas as pessoas que usam que eu conheço são pessoas excelentes. São pessoas ótimas que nunca atrapalharam a vida de ninguém. [Eu] acho que muitas pessoas falam porque tem, [mas] tem em todos os lugares. Só que ali o pessoal não faz questão de esconder tanto. Usam e não escondem e muita gente não entende isso e acha que é só ali e não é só ali, está em todo o lugar. O uso de drogas está em todo o lugar.

Eu nunca vi caso de gente drogada no corredor, de briga, pancadaria alguma coisa assim, eu nunca vi. Você vê o pessoal fumando na escada de incêndio, acho que quanto aos apartamentos cada um tem a sua regra, tipo, alguns apartamentos não permitem que fume dentro tem que ir fora, eu não acho que é diferente, por exemplo, de [outras universidades]. Entre os estudantes de humanas de [outras universidades], ou estudantes assim, eu não vejo muita diferença até mesmo na minha cidade. Tem festa o pessoal bebe, chega tem vezes que você a vê gente bêbada, mas não acho que seria pernicioso.

Eu vejo que tem pessoas que já vem pra cá e já tem histórico de uso de drogas e que sabem digamos, administrar bem isso, isso não prejudica. Eu percebo a grande maioria das pessoas que fazem uso de droga, a grande maioria já são adultos e usam droga, maconha principalmente, como quem fuma cigarro, como quem toma uma cervejinha de vez em quando. A pessoa sabe que ela não é drogada, ela não é uma viciada que está precisando de auxílio, a pessoa vai lá de vez em quando e dá um peguinha numa boa, não incomoda ninguém e nem sei também o que isso traz pra vida dela porque não parece afetar a vida social,nem estudantil, nem nada.

\section{Existem vários tipos de usuário: os que se prejudicam e os que não}

No começo da faculdade eu tinha amigos que fumavam maconha direto, fumavam mesmo, uma coisa legal, estar lá brincando, mas é aquele negócio e um tipo de vida que dá certo porque você vem de um estilo de vida muito diferente do meu, eu venho da periferia. [Essas são pessoas] que já tem uma formação muito boa e que conseguem levar o curso na boa mesmo usando a droga como essa menina que eu conheço 
conseguiu. Gente que vem de onde eu venho acaba não fazendo nada é uma questão de escolha que tem a ver com o seu tipo de vida. Eu não vou falar pra você que eu acho horrível quem usa droga, o pessoal usa droga e curte, usa droga e leva a vida e vai continuar levando, eu não julgo [acho que isso] tem muito a ver com eles, de onde eles vêm. [Tudo isso] pode ser complicado ou não dependendo também do apoio que você tem.

Eu tenho vários amigos que usam, como eu falei, que administram isso muito bem em compensação tem outras pessoas que não, mas eu acho que é muito complicado. Eu nunca usei e não tenho como apontar mais afirmativamente ah esse usou porque é maloqueiro, esse usou porque é vagabundo, esse usou porque, às vezes você tem uma pessoa que leva uma vida dita correta, tranqüila, vem a aprovar se torna usuário, então é uma questão complicada.

[Eu percebo que] depende do quanto a pessoa consome a droga no sentido do quanto ela se deixa consumir e o quanto ela consome, tem gente que se deixa consumir e tem gente que consome. Ë só essa noção de ser consumido pela droga ou consumir a sua revelia de uma maneira um pouco mais real.

\section{A porcentagem de quem precisa de ajuda é pequena}

Eu penso assim que existe muito barulho em torno das drogas, de quem usa drogas, mas na verdade quem precisa de ajuda mesmo é uma parcela pequena e que a maioria das vezes essa parcela não tem condições de buscar ajuda porque ela não quer ajuda também e são pessoas difíceis de você aproximar, eu acho muito complicado isso.

Os alunos referem ainda que as informações sobre drogas obtidas na família protegem do uso, que morar no CRUSP não trouxe muitas novidades em relação a convivência com quem usa drogas e que o período de formatura, a aproximação da saída do CRUSP geram uma série de reflexões sobre a vida.

\section{Informações sobre drogas na família protege as pessoas do consumo}

Na educação que eu recebi, a minha mãe sempre falou muito abertamente sobre as drogas com a gente 


\section{Morar no crusp não mudou sua visão sobre o usuário de drogas}

Quando eu fazia cursinho, eu já tinha amigos que usavam [drogas] e eu nem morava no CRUSP.

\section{A formatura provoca mudanças}

Quando você está perto de formatura, perto de sair daqui é que você fica pensando, o que você vai fazer e chega a hora de você acordar um pouquinho parar de sonhar tanto.

Por fim, há alguns alunos que parecem estar abertos para ampliar a compreensão do jogo complexo que está envolvido no consumo de drogas, mas têm dificuldade em formar uma opinião, assumindo uma certa dualidade no eixo aceitação-condenação.

\section{Não se posiciona frente ao usuário}

Eu procuro não ter um, uma idéia pré formada pensando quem usa droga não presta mesmo é vagabundo não sei o quê, porque muitas vezes a gente não conhece a história da pessoa e não sabe o quê que aconteceu. [Mas], às vezes é difícil às vezes dá raiva. Principalmente quando elas tem alguma atitude, por exemplo, [de] atrapalhar o sono quando você quer dormir, mas eu procuro sei lá ter uma visão mais aberta assim, não achar ah coitadinho. Mas que é um problema é eu encaro como um problema. Eu acho um problema sério, eu acho um problema sério, mas não vou falar assim putz cara condeno, não condeno, detesto, não detesto, mas é uma coisa séria. 


\section{Discussão e considerações finais}

O conhecimento sobre a história do CRUSP pelos moradores em linhas gerais pode ser considerado vago e superficial e os alunos mostram-se algumas vezes inseguros em relação a veracidade do que relatam.

O tema mais presente é o fato do CRUSP ter sido construído inicialmente para os jogos Pan-americanos, assim como realmente aconteceu, mas os detalhes dessa história, sua localização no seio dos acontecimentos mais gerais no país e suas implicações políticas não aparecem.

Pode-se dizer então que a história do CRUSP conforme contada pelos alunos é caracterizada pela fragmentação. Há, segundo eles, pouco acesso às informações, ou seja, essas são transmitidas no momento em que entram na moradia e a perda dessa oportunidade significará, no melhor dos casos, acesso casual a informações nos corredores e murais.

De fato, assim como referem alguns alunos, a história do CRUSP é marcada por reivindicações e lutas dos estudantes. No entanto, há um desconhecimento do papel da universidade nesse processo. Além disso, não há referências explícitas aos aspectos positivos dessa história. Dentre os aspectos positivos destacam-se o fato do CRUSP ter sido na década de sessenta um lugar de vida política e cultural ativa, dos alunos terem conseguido que o CRUSP voltasse a ser moradia de estudantes na época da abertura política e terem mantido apesar das pressões a gratuidade.

Vale ainda ressaltar que os fatos destacados pelos alunos são aqueles divulgados pela mídia da época (jornais), referindo-se a mortes, invasões e expulsões.

Uma análise relevante apresentada pelos alunos fala em nome de uma possível relação entre a história conturbada do CRUSP e a imagem negativa atual da moradia. Aqui vale dizer que é possível que a divulgação parcial de 
fatos da história do CRUSP, notadamente sobre os acontecimentos conturbados, se relacione ao conjunto de idéias acerca da moradia que até hoje circulam socialmente.

A discussão sobre a história do CRUSP é fundamental para a valorização da moradia pelos moradores, pela universidade e por outras instâncias que compõem a formação social.

O resgate das lutas e impasses historicamente relacionados ao conjunto residencial pode gerar o conhecimento necessário para que se aprenda com a experiência dos antecessores.

No que se refere a experiência de morar no CRUSP os alunos consideram que esse cumpre, apesar do problemas, a sua função principal que é viabilizar o curso universitário para os alunos pobres e/ou que moram longe da universidade (em um bairro muito afastado, em outra cidade, Estado ou país). São apontados vários problemas que dificultam a estadia no CRUSP e a passagem pela universidade sendo boa parte deles percebidos logo após o final da euforia de ter entrado em uma das melhores universidades do país e conquistado uma vaga no CRUSP.

Os alunos apresentam também as alternativas encontradas por eles próprios como forma de enfrentar esses problemas, visto que não sentem respaldo das instâncias administrativas da universidade. Verifica-se assim, que a solução possível tem sido buscada principalmente no plano individual.

Essa situação vivida pelos moradores do CRUSP em sua relação com a universidade não é singular e sim um reflexo do que acontece na sociedade de forma mais ampla.

Assim como afirma Chauí (1999) a universidade é uma instituição intrinsecamente relacionada com a sociedade e, portanto, sofre os efeitos do modelo político vigente - neoliberal. Nesse modelo segundo a autora as relações sociais passam a ser mediadas pelas leis do mercado, os direitos civis passam a ser vistos como favor, "neste país a educação passa a ser considerada um privilégio" (Chauí 1999 p37), como algo a ser comprado e o Estado tende a se tornar cada vez menor em importância na resolução de 
problemas relacionados à estrutura e dinâmica social. O Estado retira-se do âmbito das mediações entre capital e trabalho e omite-se com relação às políticas sociais públicas e aos problemas estruturais de maior igualdade na distribuição das riquezas que são socialmente produzidas.

Nesse sentido, a universidade oferece o mínimo necessário para que os alunos possam ter onde morar, não se apresentando para a solução de problemas estruturais que dificultam o acesso à moradia e ao cotidiano dos estudantes, ou o faz de forma muito lenta, como pode-se perceber em alguns DSCs como os seguintes: "Há problemas na forma como são distribuídas as vagas", "A COSEAS demora em resolver problemas de diversas ordens", "A instituição se omite para resolver problemas na moradia principalmente os relacionados com as drogas" e em outros de forma subliminar

O CRUSP possibilita a democratização da universidade facilitando a vida daqueles que contornaram o esquema capitalista neoliberal e mesmo sendo pobres conseguiram entrar em uma universidade pública de boa qualidade destinada aos filhos da classe rica que puderam estudar em colégios particulares, onde o ensino é de melhor qualidade na nossa sociedade. Aos alunos pobres o curso "natural", ou seja, previsto é a inserção direta no mercado de trabalho ou então o preenchimento das vagas nas universidades particulares de qualidade duvidosa (Chauí 1999).

Segundo Foracchi (1972) os jovens que ultrapassam a barreira de classe e chegam à universidade são muito mais impactados pela vivência de uma nova realidade do ponto de vista cultural do que pelos conteúdos ministrados nas salas de aula. No entanto, esse aspecto é paradoxal pois pode levar a um deslumbramento irreal dessa nova possibilidade. Já aqueles que vêm de classes mais abastadas tiveram a oportunidade de ir gradualmente construindo esse repertório cultural o que torna essa vivência parte de um processo iniciado anteriormente, não se apresentando, portanto, como uma ruptura aos padrões conhecidos.

Esse ponto de vista é compartilhado pelos alunos do CRUSP quando no Discurso do Sujeito Coletivo intitulado "Morar no CRUSP ensina a conviver com 
a diversidade" essa idéia se manifesta explicitamente "O CRUSP é uma espécie de redemoinho cultural é muito bom para quem vem das classes mais baixas. Tipo onde gente de tudo que é lugar, com diferentes experiências chega com a vontade de querer trocar na verdade com a necessidade de ter um diálogo e tal e isso foi muito bom pra mim porque até então, por exemplo, eu fui conhecer a primeira pessoa que fazia [ciências] sociais aqui na faculdade. Então na verdade você sente essa necessidade de trocar e tal aí quando você chega você fala nossa! Que mundo, é bem legal! Acho que pra mim foi positivo não só pelo lado econômico, mas pelo lado de experiência mesmo".

Toda a vivência universitária é intensificada aos moradores do CRUSP que como eles mesmos dizem vivem a universidade 24 horas por dia. Talvez seja também na moradia que os problemas da crise da universidade se agudizem ou mesmo produzam tantos sintomas como o uso de drogas e depressão.

Vários autores Chauí (1999), Menezes (1996) e Foracchi (1972) apontam a necessidade da universidade repensar seu papel e os rumos aparentemente naturais que esta instituição vem tomando. Segundo Chauí (1999) faz-se necessária uma reflexão política sobre as conseqüências da ideologia neoliberal na universidade, que propõe uma diminuição dos espaços públicos e alargamento dos privados com aniquilamento dos direitos.

Menezes (1996) afirma que (...) "Isso tudo tem contribuído para as universidades não atenderem a sinalização no sentido de que, mais do que alta especialização está fazendo falta ao profissional de nível superior uma formação geral melhor, que amplie sua visão de mundo e sua capacidade de aprender no trabalho, além do que já apontamos a ausência da vivência, de contato com a realidade, de capacidade e iniciativa" ( $p 58$ ).

Foracchi (1971) aponta que a universidade está imersa em uma sociedade tecnológica, com grupos cujos interesses são opostos e que não possuem um compromisso maior com a cultura estando sim centralizados na comercialização de seus produtos. É nesse contexto que estão imersos os moradores do CRUSP com seus anseios e angústias. 
Deve-se, portanto, analisar as questões trazidas pelos Discursos do Sujeito Coletivo dos moradores sobre dois ângulos um macro estrutural, que procuramos fazer até aqui analisando o impacto do projeto neoliberal na vida universitária ressaltando a importância de repensá-la e também analisar questões do micro cosmo do CRUSP que serão apresentadas a partir de agora. Ambas estão intrinsecamente relacionadas, ficando a separação apenas a cargo de organizar a discussão.

Algumas questões que merecem destaque nesta discussão são levantadas pelos alunos, sendo a primeira delas o lazer que parece ser para muitos uma atividade esporádica devido a uma série de problemas, sendo também pouco estudado e percebido como uma questão secundária mesmo em trabalhos acadêmicos (Abramo 1994). Mas "o lazer para os jovens, aparece como um espaço especialmente importante para o desenvolvimento de relações de sociabilidade, das buscas e experiências através das quais procuram estruturar suas novas referências e identidades individuais e coletivas" (Abramo 1994 p 62).

Outro aspecto discutido é a dificuldade dos moradores na vivência coletiva, com predominância do individualismo. Mais uma vez estamos diante de uma questão da sociedade capitalista pós-moderna, pois essa é a principal forma de relacionamento das pessoas e assim se repete o padrão na universidade. Segundo Bock (2000) o individualismo acontece entre outros fatores porque por princípio os colegas são concorrentes, podemos acrescentar que com a crescente violência as pessoas desconhecidas ou com as quais temos um contato superficial são vistos como potencialmente perigosas.

Os alunos também referem sofrer preconceito pelo fato de morar no CRUSP e mostram-se por vezes preconceituosos em relação por exemplo aos consumidores de drogas. O preconceito é uma construção de natureza ideológica. As generalizações provenientes da mídia, que se encarrega de expor os acontecimentos negativos e explosivos a respeito da moradia e dos moradores, e aquelas provenientes da chamada lei do menor esforço que 
caracteriza o cotidiano das pessoas são mecanismos indutores do preconceito (Konder. 2002).

No caso dos consumidores de drogas, a formação social incumbiu-se de utilizar a categoria drogado como uma categoria de acusação que em si encerra um conjunto totalizador de negatividades, em que os acusados são moralmente nocivos e podem ameaçar o status quo (Velho, 1999 p.60).

A idéia de que o CRUSP não é o responsável pelo consumo de drogas de alguns moradores está presente na fala de muitos alunos. Os alunos apresentam motivações variadas para o início do uso, sendo que essas não se referem necessariamente ao CRUSP. Nota-se nos discursos dos moradores que eles procuram desfazer a relação simplista e preconceituosa que culpabiliza o CRUSP pelo uso de drogas e que afirma que lá o uso é maior do que, por exempl, o em outros locais dentro da universidade.

No que se refere a moradia de forma geral uma sugestão importante apresentada para os alunos e que se apresenta como alternativa viável para busca de soluções para os problemas vividos pelos moradores é a realização de pesquisas científicas que proporcionem um conhecimento mais aprofundado da realidade dos moradores do CRUSP. É preciso conhecer a realidade para que se possa transformá-la.

Os moradores do CRUSP consituem um grupo heterôgenio sob vários aspectos, pois são pessoas que vêm de cidades, Estados e países diferentes, com tradições e culturas distintas e isso se reflete na visão desses moradores sobre o uso e o usuário de drogas e nas sugestões para amenizar os possíveis problemas relacionados ao consumo de drogas na moradia. Além disso, são influenciados em graus diferentes e com críticas diferenciadas, pela ideologia dominante sobre o tema - repressiva.

Dessa forma, há discursos conservadores e repressores com propostas de coerção da liberdade e punição severa aos usuários de drogas, culpabilização desses pelos problemas advindos do uso de drogas e desvalorização dos usuários proferidos em parte por alunos que se sentem de alguma forma ameaçados ou incomodados por esses usuários. 
Segundo Zaluar (1994) as propostas repressivas e punitivas não tem sido eficazes no que se propõe, eliminar as drogas, mas disseminam o preconceito contra o usuário de drogas. Dentre as propostas repressivas a mais expressiva é a chamada guerras as drogas e os Estados Unidos é o país que lidera essa cruzada anti-drogas com uma política repressiva e violenta indistintamente contra o usuário, dependente, traficante e o produtor da droga. Mas essa estratégia não tem nem mesmo diminuído as taxas de criminalidade (Zaluar 1994).

A pergunta que se faz é porque se mantém essa política? A resposta não é simples, pois há uma complexa trama de interesses políticos e econômicos e não é objetivo desse trabalho explorá-la. Pode se dizer de forma resumida que essa política tem sido uma forma de dominação Americana em relação aos países Latino Americanos principalmente e que a guerra contra as drogas alimenta o mercado, por exemplo, de armas (Coggiola, 2001; Kaplan 1997). Além disso, segundo Karan (2003) "a hostilidade e o medo despertado facilitam a intensificação do controle social, a ampliação do poder do Estado de punir e o simultâneo enfraquecimento do Estado Democrático de Direito" (p 64).

A culpabilização do indivíduo por sua dependência, a visão exclusivamente relacionada a aspectos negativos do usuário presentes no discurso dos alunos assim como na sociedade de forma geral encontram reforço na mídia. Essa tem preferido destacar as desgraças vividas por pessoas que têm problemas sérios advindos do uso de drogas, os conflitos entre as organizações criminosas e a polícia e as apreensões de drogas do que as alternativas encontradas para minimizar os problemas dos dependentes de drogas e a discussão sobre os determinantes do consumo (Bastos 2003).

Carlini-Cotrin e col (1995) afirmam que a mídia tem um papel fundamental na fabricação de um verdadeiro estado de pânico na população brasileira uma vez que grande parte dessa população só tem acesso a informações veiculadas nos meios de comunicação de massa.

Os estudos sobre as informações veiculadas na mídia escrita sobre drogas realizados por Carlini-Cotrim e col (1995) e Noto e col (2003), concluem 
que as drogas que mais aparecem nas reportagens não são aquelas mais usadas pela população (álcool e tabaco) de acordo com os estudos epidemiológicos.

O esperado seria que houvesse uma distribuição mais equilibrada e compatível com os indicadores epidemiológicos. Esta desproporção reflete-se na percepção da população, e distorce as crenças relativas ao consumo de drogas no Brasil.

Essa distorção sobre os diferentes aspectos que envolvem o tema drogas está presente também nos livros didáticos usados em escolas de primeiro e segundo graus. Em pesquisa sobre a abordagem do tema drogas em livros didáticos verifica-se que o conteúdo apresentado está permeado pela pedagogia do amedrontamento e pelo conceito de dependência. Não se discute os dados sobre incidência, não se analisam as causas e não há referência sobre a prevenção (Carlini-Cotrim 1991). Esta situação também é encontrada nos textos oficiais (Bucher, Oliveira 1994). Assim vai se estabelecendo uma visão acrítica e distorcida do tema.No entanto, há um contraponto a essas idéias até aqui apresentadas, são os discursos dos alunos que reconhecem a importância da contextualização do uso de drogas, a relativização do julgamento do usuário de drogas (como herói ou bandido) e que fazem propostas de prevenção interativa, a partir do conhecimento da realidade do usuário objetivando a superação do preconceito e a promoção de um debate social mais amplo.

Velho (1994) ressalta a importância da contextualização do uso de drogas e afirma que as generalizações têm apenas contribuído para a estigmatização dos usuários. O autor refere que a Antropologia tem ajudado na compreensão de que existem diferentes maneiras de usar drogas em função de variáveis culturais e sociológicas. Portanto, não se deve homogeneizar o comportamento dos usuários de drogas, o estilo de vida e a condição de classe que são determinantes na particularidade que o consumo de determinada substância pode ter em determinado grupo em determinado momento histórico. 
Zaluar (1994) concorda com Velho (1994) e afirma que "não se pode concluir que todos os usuários de drogas são iguais ou até professem o mesmo credo cultural" ( $p$ 13). Para essa autora existem diferenças no grau de envolvimento com a droga e com o grupo, o que se reflete no lugar que a droga ocupa na vida das pessoas.

Alguns discursos apresentam temas importantes e que fogem dos estereótipos sociais vigentes. Um exemplo é o discurso intitulado "As pessoas não mudam seu comportamento porque usam drogas" tema polêmico e que está em concordância com o que afirma Bastos (2003) "nenhuma substância determina comportamentos, mas tão somente contribui para a explicitação de comportamentos e atitudes que já são característicos da pessoa"(p 37).

Os alunos apresentam também a idéia de que o uso de drogas no CRUSP está relacionado aos processos de socialização. Bastos (2003) afirma que de forma geral o primeiro contato com a droga acontece em atividades sociais, que em termos gerais podem ser situações de festas, churrasco, encontro de amigos. Portanto, há particularidades do CRUSP nesse processo e semelhanças com o que acontece na sociedade de forma geral.

As propostas de prevenção ao uso indevido de drogas apresentadas pelos moradores se coadunam com os pressupostos da redução de danos. Nessa proposta, diferentemente da guerra às drogas e tolerância zero, postulase que o uso de drogas sempre existiu e que trabalhar com o propósito de conquistar um mundo sem drogas é irreal (Marlatt 1999).

Na proposta de redução de danos procura-se desviar a atenção do uso de drogas para se discutir as conseqüências e os efeitos do comportamento do adicto e embora reconheça a importância da abstinência aceita e trabalha com alternativas que reduzam os riscos relacionados ao consumo de drogas (Marlatt 1999).

Nos programas de prevenção em redução de danos a educação é o elemento primordial, valoriza-se a informação trazida pelos participantes, o especialista não se coloca no lugar de único detentor do saber, o formato das 
atividades é interativo, com estímulo à discussão e com a participação de todos (Marlatt 1999).

Outra sugestão apresentada pelos alunos é a realização de um debate social amplo. Bastos (1994) afirma que essa é uma alternativa viável. O debate deve reunir diferentes setores da sociedade com posições contrastantes, que devem ser respeitadas. Assim, pode-se formular políticas públicas sintonizadas com os pontos de vista da maioria sem excluir as minorias.

Partindo do pressuposto que a universidade pública tem o dever de promover esse debate e outras atividades que previnam os prejuízos que possam advir do consumo de drogas junto aos universitários (Soares, Faria 2000), concordamos com as idéias sobre prevenção trazidas pelos alunos, que sugerem que o tema uso de drogas no CRUSP seja amplamente discutido com essa comunidade. $O$ objetivo desse fórum de discussão pode ser 0 estabelecimento de uma política sobre o uso de drogas no CRUSP, o esclarecimento sobre o encaminhamento para o tratamento da dependência e a formulação de um programa de prevenção ao uso indevido de drogas que se proponha a desenvolver atividades de lazer e promova interação entre os moradores. O processo não é simples, mas é viável, pode-se começar com os calouros do CRUSP, sugestão dada pelos próprios alunos. 


\section{Referências Bibliográficas}

Abramo HW. Cenas juvenis: punks e darks no espetáculo urbano. São Paulo Página Aberta; 1994.

Andrade AG, Queiroz S, VillaBoim RCM, César CLG, Alves CGP, Bassit AZ, Gentil V, Siqueira AAF, Tolosa EMC. Uso de álcool e drogas entre alunos de graduação da Universidade de São Paulo(1996). Rev ABP-APAL 1997; 19 (2): 53-9.

Andrade AG, Bassit AZ, Mesquita AM, Fukuhima JT, Gonçalves EL. Prevalência do uso de drogas entre alunos da Faculdade de Medicina da Universidade de São Paulo (1991-93).Rev ABP-APAL 1995; 17 (2) 41-6.

Andrade AG, Bassit AZ, Kerr-Correa F, Tonhon AA, Boscovitz EP, Cabral M, Rassi $R$ et al. Fatores de risco associados ao uso de álcool e drogas na vida, entre estudantes de medicina do Estado de São Paulo. Rev ABP-APAL 1997; 19(4) 117-26.

Ariés P. História social da criança e da família. $2^{a}$ edição. Rio de Janeiro; LTC; 1981 As idades da vida; p. 29-50.

As obras no CRUSP afastam marginais. O Estado de São Paulo, São Paulo, 29 de março. 1984. p. 15.

Universidade de São Paulo. A prefeitura da cidade universitária "Armando Salles Oliveira”. O espaço da USP: presente e futuro. São Paulo; 1985.

Barata A. Introdução a uma sociologia da droga. In: Mesquita F, Bastos IB, organizadores. Drogas e Aids: estratégias de redução de danos. São Paulo: Hucitec; 1994. p.21-43

Bardin L. Análise de conteúdo. Trad. de Luís Antero Reto e Augusto Pinheiro. Lisboa: Edições 70; 1977.

Barria ACR, Queiroz S, Nicastri S, Andrade AG. Comportamento do universitário da área de biológicas da Universidade de São Paulo. Rev Psiq Clin 2000; 27 (4):215-24.

Bastos Fl. Redução de danos e saúde coletiva: reflexões a propósito das experiências internacional e brasileira. In: Sampaio CM, Campos MA, 
organizadores. Drogas, dignidade e inclusão social: a lei prática da redução de danos. Rio de Janeiro: Aborda; 2003. p. 15-41.

Becker HS. Métodos de pesquisa em ciências sociais. $2^{a}$ ed. São Paulo: Hucitec; 1994. Estudo de práticas de crimes e delitos. p. 153-65.

Birman J. Mal-estar na atualidade: a psicanálise e as novas formas de subjetivação. $2^{\mathrm{a}}$ ed. Rio de Janeiro: Civilização Brasileira; 2000.

Bock S. A inserção do jovem no mercado de trabalho. In: Abramo HW, Freitas MV, Sposito MP, organizadoras. Juventude em debate. São Paulo: Cortez; 2000. p

Borini P, Oliveira CM, Martins MG, Guimarães RC. Conceitos, concepções etiológicas e atitudes de estudantes de medicina sobre o uso e abuso de álcool. Correlações com os padrões de uso- parte 2. J Bras Psiq 1994; 43(3) 123-31,

Boskovitz EP, Cruz ETN, Chiaravalloti Neto F, Moraes MS, Paiva Neto JV, Ávila LA et al. Uso de drogas entre estudantes universitários em São José do Rio Preto, São Paulo. Rev Psiq Clin 1995; 22(3): 87-93.

Brenes LFV, Hammes MF, Sole MT, Hein R, Ramil KAA. Drogas ilícitas entre universitários. Armigs 1986; 30 (2) 140-3.

Briga e duas mortes na USP. Jornal da Tarde, São Paulo, 12 de nov. 1984. p 2.

Bucher R; Totugui ML. Conocimento y uso de drogas entre alumnos de Brasília. Acta Psiqu.psicol, Am. Lat 1988; 34: 113-26.

Bucher R. A ética da prevenção. Psicol. Teor Pesq 1992; 8(3): 385-98.

Bucher R. A abordagem preventiva do uso indevido de drogas In: Bucher R organizador Prevenção ao uso indevido de drogas. Universidade de Brasília, 1989, Brasília: UNB/CETAD/CORDATO; 1989.

Bucher R, Oliveira S. O discurso do "combate às drogas" e suas ideologias. Rev. Saúde Públ. 1994: 28(2): 137-45.

Carlini EA, Carlini-Cotrim B, Silva AR. Sugestões para Programas de Prevenção ao abuso de drogas no Brasil. São Paulo: CEBRID, 1990.

Carlini EA, D’Almeida V, Noto AR, Sá LC. Produção científica brasileira sobre abuso de drogas: como está e para que serve.J Bras Psiq, 1994; 43(8): 423-7. 
Carlini-Cotrim B. O consumo de substâncias psicotrópicas por estudantes secundários: o Brasil frente à situação internacional". Rev ABP-APAL 1991; 13(3):112-6.

Carlini-Cotrin B. A escola e as drogas: realidade brasileira e contexto internacional. [tese] São Paulo (SP): Faculdade de Psicologia da PUC SP, 1992.

Carlini-Cotrim B, Rosemberg F. Os livros didáticos e o ensino para a saúde: ocaso das drogas psicotrópicas. Rev Saúde Pública 1991; 25(4): 299-305.

Carlini-Cotrim B, Galduróz JCF, Noto AR, Pinsky I. A mídia na fabricação do pânico de drogas: um estudo no Brasil. Comunicação Política 1995; 1: 217- 30.

Chauí M. O que é ideologia? 2ª ed São Paulo: Brasiliense; 2001.

Chauí M. Ideologia neoliberal e universidade. In: Oliveira F, Paoli MC, organizadores. Os sentidos da democracia: políticas do dissenso e hegemonia global. Rio de Janeiro: Vozes; 1999. p. 27-51.

Coggiola O. O comércio de drogas hoje. Olho da História [periódico online] 2001; (4). Disponível em: <http://www.ufba.br/ revistao/04coggio.html> (14 set 2001).

Coordenadoria de Assistência Social - COSEAS Perfil sócio-econômico dos moradores do CRUSP- Graduação. São Paulo; 1999.

Coordenadoria de Assistência Social - COSEAS. Documentos internos. São Paulo; [s.d.] (mimiografado).

CRUSP voltará a ter redsidentes em março. O Estado de São Paulo, São Paulo, $1^{\circ}$. de fev.1983. p 12.

Cunha DRR. O CRUSP visto por um mineiro. [online]. São Paulo; [s.d.]. Dsiponível em: <www.crusp.cjb.ne t> (17 ago 2003).

De Lucia R, Planeta CS. Padrões de uso de psicoestimulantes e energizantes por universitários: análise do período 1983-1988. Rev ABP-APAl 1989; 11(3): 111-3.

Demartini ZBF. A questão da análise no processo de pesquisa. In: Lang ABSG, organizadora. Desafios da pesquisa em Ciências Sociais. São Paulo: NAPCERU; 2001. p. 49-72. (textos. série 2, n 8).

Degradação no campus. Folha de São Paulo, São Paulo, 22 de março. 1984. 
Docentes acham que haverá uma corrida ao CRUSP. Folha de São Paulo, São Paulo, 3 de fev. 1983. p.14.

Duas mortes no CRUSP. O Estado de São Paulo, São Paulo, 25 de nov. 1984.

Escohotado, A. Las drogas. De Los orígenes a la prohibicioón. Madrid: Alianza Editorial, 1994.

Foracchi MM. Frustrações dos jovens e orientação do protesto estudantil. In: Florestan F, organizador. Comunidade e sociedade no Brasil: leituras básicas de introdução ao estudo macro-sociológico do Brasil. São Paulo: Nacional; 1972. p 559-71.

Foracchi MM. A juventude na sociedade moderna. São Paulo: Pioneira; 1972.

Galduróz JCF, Noto AR, Carlini EA. IV Levantamento sobre o uso de drogas entre estudantes de $1^{\circ}$ e $2^{\circ}$ graus em dez capitais brasileiras: 1997. São Paulo: CEBRID/UNIFESP; 1997.

Karan, ML Drogas: o processo legislativo. In: Ribeiro MM, Seibel SD organizadores. Drogas: hegemonia do cinismo. São Paulo: Memorial; 1997.

Karan ML. Redução de danos, ética e lei: os danos da política proibicionista e as alternativas compromissadas com a dignidade do indivíduo. In: Sampaio CM, Campos MA, organizadores. Drogas, dignidade e inclusão social: a lei prática da redução de danos. Rio de Janeiro: Aborda; 2003. p. 45-97.

Kerr-Corrêa F, Andrade AG, Bassit, AZ, Boccutto NMVF. Uso de drogas por estudantes de medicina da UNESP. Rev Bras.Psiqu 1999; 21(2): 95-100.

Kaplan M. Tráfico de drogas, soberania estatal, seguridad nacional. Sistema. 1997; (136): 43-61.

Konder L. A questão da ideologia. São Paulo: Companhia das Letras; 2002. Ideologia e cotidiano. p. 237-47.

Lapassade G. A entrada na vida. Lisboa: Edições 70, 1975.

Lefevre F, Lefevre AMC Teixeira JJV. Organizadores. O discurso do sujeito coletivo: uma nova abordagem metodológica em pesquisa qualitativa. Caxias do Sul: EDUCS; 2000.

Lefevre F, Lefevre AMC. A fala do social: discurso do sujeito coletivo como uma nova ferramenta em pesquisa qualitativa. São Paulo; 2002 [Apostila do curso 
Pesquisa qualitativa e representação social da saúde e doença: aspectos metodológicos e instrumentais].

Magalhães MP, Barros RS, Oliveira RC.; Azevedo RB, Almeida SP, Silva MTA. Avaliação dos efeitos da maconha por usuários de população estudantil. Ci Cult 1986; 41(7): 652-57.

Magalhães MP; Barros RS; Oliveira, RC; Azevedo RB; Almeida SP, Silva MTA. Padrões e freqüência do uso da maconha por estudantes universitários. Rev ABP-APAL 1989; 11(1) 34-40.

Magalhães MP, Barros RS, Silva MTA. Uso de drogas entre universitários: a experiência da maconha como fator delimitante. Rev ABP-APAL 1991; 13:97104.

Marlatt GA, Baer JS, Blume AW, Daisy F, Dimeff LA, Gorman EM et al. Redução de danos: estratégias práticas para lidar com comportamentos de alto risco. São Paulo: Artemed; 1999. Princípios básicos e estratégias de redução de danos; p. 46-58.

Mendes LC. Para a universidade brasileira transpor o século. Rev Serv Social Soc 1996; 17(51): 49-60.

Mesquita AMC, Bucaretchi HA, Castel S, Andrade AG. Estudantes da Faculdade de Medicina da Universidade de São Paulo: uso de substâncias psicoativas em 1991.Rev ABP-APAL 1995; 17(2):47-54.

Minayo, MCS. O desafio do conhecimento. Pesquisa qualitativa em saúde. SPRJ: Hucitec-Abrasco; 1994. Fases do trabalho de campo; p 105-197.

Moradores acham que a COSEAS vai restringir CRUSP. Folha de São Paulo, São Paulo, 2 de fev.1983. p. 15.

Moradores do CRSP criam associação e pedem garantia. Folha de São Paulo, São Paulo, 8 de dez. 1984.

Morin E. Cultura de massas no século XX: Espírito do tempo - I. Neurose. $9^{\mathrm{a}}$. ed. Forense; 1997. Juventude; p. 147-57.

Nappo SA. Análise qualitativa do uso de cacaína: um estudo em São Paulo. In: Leite MC, Andrade AG, organizadores. Cocaína e crack: dos fundamentos ao tratamento. São Paulo: Artemed; 1999. p.205-226. 
Noto AR, Batista MC, Faria ST, Nappo S, Galduroz JCF, Carlini EA. Drogas na imprensa brasileira: uma análise dos artigos publicados em jornais e revistas. Cad Saúde Pública 2003; 19(1): 69-79.

Noto AR, Nappo S, Galduroz JCF, Mattei R, Carlini EA. IV Levantamento sobre o uso de drogas entre crianças e adolescentes em situação de rua.São Paulo: CEBRID/UNIFESP; 1998.

Novaes RR. Juventude e participação social: apontamentos sobre a reinvenção da política. In: Abramo HW, Freitas MV, Sposito MP, organi zadoras. Juventude em debate. São Paulo: Cortez; 2000. p 46-54.

Queiroz VM, Salum MJ. Globalização econômica e a apartação da saúde: reflexão crítica para o pensar/fazer na enfermagem. In: Anais do $48^{\circ}$.Congresso Brasileiro de Enfermagem; 1997. São Paulo: ABEn- São Paulo-SP;1997. p. 190-207.

Reformas e interdição do CRUSP ainda sem acordo. Folha da tarde, São Paulo, 29 de dez. 1984.

Sá, DB. Capacidade civil: um direito penal? In Bastos FI, Gonçalves OD. Drogas: É legal? Um debate autorizado. Rio de Janeiro: Imago; 1993.

Salum MJL. Defesa da Universidade pública: a responsabilidade em construir novas sociabilidade, educação, saúde e enfermagem. Univ Soci. São Paulo: 2001; 10(23): 173-183.

Santos LV, Silva WO, Damásio VF, Stacciarine JM, Munari DB. Percepções de estudantes da área de saúde sobre o abuso de álcool no meio acadêmico. In: Anais do VI Encontro de Pesquisadores em Saúde Mental e V Encontro de Especialistas em Enfermagem Psiquiátrica; 2000 abril.17-20; Ribeirão Preto. São Paulo: EERP-USP; 2000 p 199-209.

Schaiber LB. Pesquisa qualitativa em saúde. Reflexões metodológicas do relato oral e produção de narrativas em estudo sobre profissão médica. Rev Saúde Pública 29 (2), 1995

Schivoletto S, Henriques SG, Andrade AG. Uso de drogas por adolescentes que buscam atendimento ambulatorial: comparação entre "crack" e outras drogas ilícitas - um estudo piloto. Rev ABP-APAL 1997; 19(1): 7-17.

Soares CB. Adolescentes, drogas e AIDS: avaliando a prevenção e levantando necessidades. [Tese]. São Paulo (SP): Faculdade de Educação da USP; 1997.

Soares CB, Faria LM. Prevenção de drogas no meio universitário: uma experiência na Universidade de São Paulo. Participação 2000; 4(6):45-7. 
Spósito MP. Jovens e educação: novas dimensões da exclusão. Rev Em aberto. Brasília 1992; 11(56): 43-53.

Queiroz S. Fatores de risco para o uso de drogas entre alunos de graduação da Universidade de São Paulo. [tese]. São Paulo (SP): Faculdade de Saúde Pública da USP; 2000.

Velho G. Individualismo e cultura: notas para uma antropologia da sociedade contemporânea Rio de Janeiro: Jorge Zahar; 1999. Duas categorias de acusação na cultura brasileira contemporânea; p 55- 64 .

Velho G.A dimensão cultural e política dos mundos das drogas. In: Zaluar A. Drogas e cidadania. São Paulo: Brasiliense; 1994. p. 23-30.

Zaluar A. Dorgas e cidadania. São Paulo: Brasiliense; 1994. p 7-22.

Zanini AC, Moraes ECF, Akerman B, Aizenstein M, Salgado LFV. Concepts and use of psychoative drugs among university students in the São area. Drug Forum 6 1977; 85-99. 
Anexo 1 
Anexo 2 
Anexo 3 


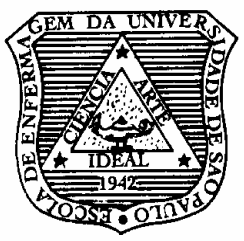

\section{UNIVERSIDADE DE SÃO PAULO \\ ESCOLA DE ENFERMAGEM \\ DEPARTAMENTO DE ENFERMAGEM \\ EM SAÚDE COLETIVA}

Av. Dr. Eneas de Carvalho Aguiar, 419 - CEP 05403-000

Tel.: (011) 3066-7652 - FAX 3066-7662

\section{TERMO DE CONSENTIMENTO LIVRE E ESCLARECIDO}

\section{O consumo de drogas: o que pensam os alunos moradores do Conjunto Residencial da USP - CRUSP}

Meu nome é Thais Helena Mourão Laranjo e sou aluna de PósGraduação em Enfermagem, nível de Mestrado, Departamento de Enfermagem em Saúde Coletiva da Escola de Enfermagem da Universidade de São Paulo. Estou desenvolvendo a pesquisa "Consumo de drogas: o que pensam os alunos moradores do Conjunto Residencial da USP - CRUSP".

O objetivo deste estudo é conhecer as opiniões dos alunos moradores do CRUSP a respeito do uso de drogas de forma a contribuir para que as atividades preventivas propostas estejam mais próximas da realidade deste grupo.

Assim, solicitamos através deste documento, o seu consentimento para participar do estudo, através de entrevista gravada, estando ciente de que essas informações serão utilizadas para fins de pesquisa.

Não é necessário que você se identifique e será mantido o sigilo das informações. Informamos ainda que a não participação no estudo não the causará qualquer prejuízo e que você pode desistir de participar da pesquisa a qualquer momento. No entanto, ao participar, compromete-se a fornecer informações verídicas.

Desde já agradecemos a sua colaboração e colocamo-nos à disposição através do telefone 3066-7652 do Departamento de Enfermagem em Saúde Coletiva.

Profa. Dra. Cássia Baldini Soares

Orientadora

Depto Enfermagem em Saúde Coletiva
Thais Helena Mourão Laranjo

Mestranda

Depto Enfermagem em Saúde Coletiva

São Paulo, 
Anexo 4 


\section{ROTEIRO DAS ENTREVISTAS}

\section{Caracterização da inserção social}

1. Há quanto tempo mora no CRUSP?

2. Onde mora sua família?

3. Com que regularidade você vai visitar os seus pais?

4. O que os seus pais fazem. Qual que é ocupação deles?

5. Até que série eles estudaram?

6. Qual a sua idade?

7. Você é casado?

8. Você tem filhos?

9E a sua fonte de renda, qual é?

10. Pra gente pegar em termos de salário mínimo quanto que é, um salário mínimo, dois a grana que você vive?

11. Que curso você está fazendo?

12. Em que ano está?

13. Em que período estuda?

\section{Perguntas específicas sobre o tema da pesquisa}

1. O que você sabe sobre a história do CRUSP?

2. Eu queria que você descrevesse pra mim como é morar no CRUSP?, o quê que tem de positivo e negativo

3. Você participa de atividades sociais, políticas, de lazer, esportivas que tem na moradia? Tem alguma coisa desse tipo lá, específico para os moradores? E no final de semana?

4. Em relação ao uso de drogas como você percebe o uso de drogas no CRUSP?

5.O que você acha de quem usa drogas? Qual a tua opinião?

6. O que você acha de uma idéia que existe na universidade de que o CRUSP é um ambiente que propicia o uso de drogas?

7. O que você acha que poderia ser feito em relação ao uso de drogas no CRUSP? 